\title{
QUALIDADE DO ESPAÇO VERDE URBANO: UMA PROPOSTA DE ÍNDICE DE AVALIAÇÃO
}

\section{IVAN ANDRÉ ALVAREZ}

Tese apresentada à Escola Superior de Agricultura "Luiz de Queiroz", Universidade de São Paulo, para obtenção do título de Doutor em Agronomia, Área de Concentração: Fitotecnia.

P I R A C I C A B A

Estado de São Paulo - Brasil

Fevereiro - 2004 


\title{
QUALIDADE DO ESPAÇO VERDE URBANO: UMA PROPOSTA DE ÍNDICE DE AVALIAÇÃO
}

\section{IVAN ANDRÉ ALVAREZ}

Engenheiro Agrônomo

Orientador: Prof. Dr. ANA MARIA LINER PEREIRA LIMA

Tese apresentada à Escola Superior de Agricultura "Luiz de Queiroz", Universidade de São Paulo, para obtenção do título de Doutor em Agronomia, Área de Concentração: Fitotecnia.

\author{
P I R A C I C A B A \\ Estado de São Paulo - Brasil
}

Fevereiro - 2004 


\title{
Dados Internacionais de Catalogação na Publicação (CIP) \\ DIVSÃO DE BIBLIOTECA E DOCUMENTAÇÃO - ESALQ/USP
}

\author{
Alvarez, Ivan André \\ Qualidade do espaço verde urbano: uma proposta de índice de avaliação / \\ Ivan André Alvarez. - - Piracicaba, 2004. \\ 187 p. : il. \\ Tese (doutorado) - Escola Superior de Agricultura Luiz de Queiroz, 2004. \\ Bibliografia. \\ 1. Ambiente urbano 2. Arborização de rua 3. Arquitetura paisagística 4. \\ Cober-tura do solo 5. Geoprocessamento 6. Hidrologia urbana 7. Meio \\ ambiente 8. Plane-jamento territorial urbano 9. Qualidade de vida 10. \\ Silvicultura I. Título
}

CDD 711.4 
"NADA NESTE MUNDO

É TÃO PODEROSO COMO UMA IDÉIA CUJA OPORTUNIDADE CHEGOU"

Victor Hugo 
À minha eterna amada

Inessa

pelo companheirismo e a afinidade de ideais

Ao meu filho

Iago

pelos seus ensaios de sorriso que me inspiraram durante a redação da tese

Dedico 


\section{AGRADECIMENTOS}

À Prof. Dra. Ana Maria Liner Pereira Lima, pela orientação dedicada, amizade e companheirismo nos ideais de uma cidade mais arborizada;

Ao Prof. Dr. Roberval de Cássia Salvador Ribeiro, pelo apoio, amizade e revisão criteriosa;

À Prof. Dra. Marina André de Alvarez, pelas sugestões, pelas críticas e por ensinar que a Ciência também deve levar em consideração a intuição e o pensamento holístico;

Ao Prof. Dr. Valdemar Antônio Demétrio, pelo incentivo e amizade;

Ao Prof. Dr. Hilton Tadeu Zarate do Couto, pelas sugestões e pela cessão dos equipamentos para a videografia e o geoprocessamento;

Ao Prof. Demóstenes da Silva, pelo apoio para realização do trabalho;

Ao Prof. Dr. Paulo Roberto de Camargo e Castro, pelo apoio para realização de meus ideais;

Ao Prof. Décio Barbin, pelo auxílio nos cálculos matemáticos e pela amizade constante;

Ao Prof. Dr Camilo Daleles Rennó e Prof. Dr João Vianei Soares, pela cessão das imagens de satélite; 
Aos amigos Henrique Sundfeld Barbin e Giuliana Del Nero Velasco, pela coleta de dados e por tudo;

À Prof. Fernanda Bacellar, pelo incentivo, amizade e revisão do summary;

À amiga Bernadete Barbin, pelo apoio e amizade incondicional;

Ao funcionário Jéfferson Lordello Polizel do Departamento de Ciências Florestais, pelo prestimoso auxílio no vôo e em todas as etapas de laboratório;

À Prof. Ms. Ana Cristina Schilling, pelas sugestões matemáticas;

À Engenheira Florestal Elisa Harumi Takashiba, pelo apoio durante o geoprocessamento;

À Engenheira Florestal Roberta Valente, pelo apoio na utilização do software IDRISI;

Aos amigos do paisagismo Isabel C. Fialho Harder, Helena B. Freire e Taís O. Andrade, pelo companheirismo durante todo o Doutorado;

Aos funcionários do Departamento de Produção Vegetal, em especial à Luciane A. Lopes, pela amizade;

Ao Prof. Dr. Felisberto Cavalheiro (in memorian), pelo incentivo e pelo exemplo de toda uma vida dedicada ao paisagismo;

À CAPES, pela concessão de bolsa;

Enfim, a todos que contribuíram na minha formação e, que de alguma maneira, estiveram presentes em algum momento deste trabalho. 


\section{SUMÁRIO}

Página

LISTA DE FIGURAS ................................................. xii

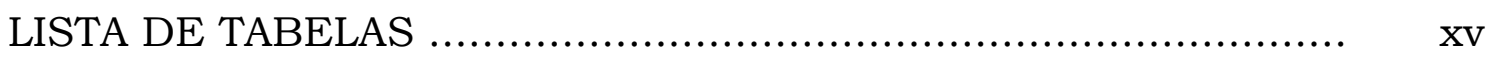

RESUMO ......................................................... xviii

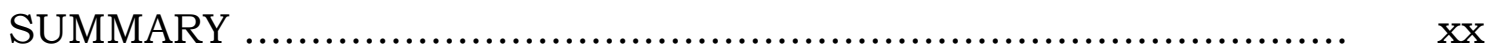

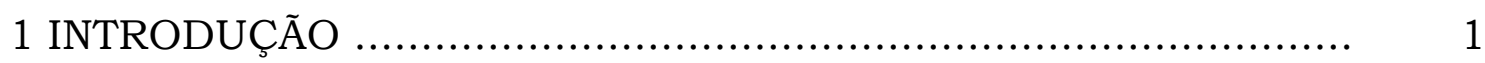

2 REVISÃO BIBLIOGRÁFICA........................................... 5

2.1 Levantamento da arborização viária ............................... 5

2.2 Espaços livres e índices ......................................... 11

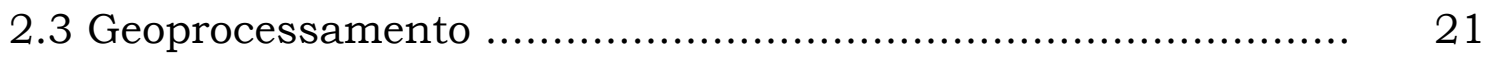

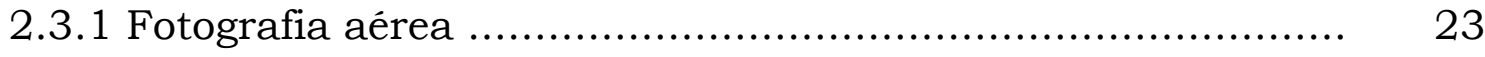

2.3.2 Videografia .................................................... 25

2.3.3 Imagem de satélite ........................................... 26

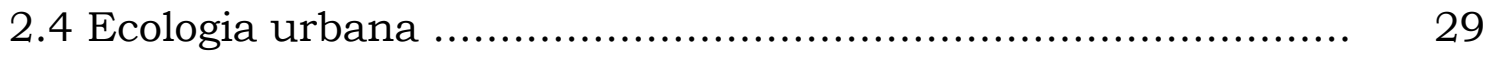

2.4.1 Climatologia urbana - calor ..................................... 29

2.4.1.1 Diversidade de Ilhas de Calor Urbanas (UHI) ................. 31

2.4.1.2 Estocagem e fluxo de calor antropogênico no balanço energético urbano ............................................ 33 
2.4.1.3 Balanço de energia do meio urbano ............................... 34

2.4.2 Hidrologia .......................................................... 35

2.5 Qualidade da vegetação urbana ...................................... 37

2.5.1 Função ecológica .................................................... 38

2.5.2 Parâmetros para avaliação da função ecológica .................. 38

2.5.2.1 Luminosidade e temperatura ................................... 39

2.5.2.2 Umidade ............................................................ 42

2.5.2.3 Composição do ar ..................................................... 44

2.5.2.4 Velocidade do vento........................................... 47

3 MATERIAL E MÉTODOS ...................................................... 49

3.1 Local de estudo ...................................................... 50

3.1.1 Municipio de Piracicaba .......................................... 50

3.1.2 Definição da unidade básica de estudo ............................. 51

3.1.3 Bairro Santa Cecília (Piracicaba - SP) ........................... 51

3.2 Arborização viária ....................................................... 53

3.2.1 Comparação entre censo, amostragem aleatória simples e amostragem estratificada na arborização viária de calçadas ...... 53

3.2.1.1 Amostragem aleatória simples .................................. 55

3.2.1.2 Amostragem estratificada .................................... 57

3.3 Inventário quali-quantitativo do espaço verde viário ............... 59

3.3.1 Espaço verde das calçadas ........................................... 60

3.3.1.1 Arborização nas calçadas ........................................... 60

3.3.1.2 Piso das calçadas ................................................ 61

3.3.2. Espaço verde de acompanhamento viário ......................... 62

3.4 Índice de Espaço Livre de Uso Público (IELUP) e Porcentagem de Espaço Livre de Uso Público (PELUP) ............................ 62

3.4.1 Estudo dos espaços livres de uso público ....................... 62 
3.4.1.1 Situação do bairro Santa Cecília em 2003.................... 62

3.4.1.2 Identificação dos espaços livres de uso público ................ 63

3.4.1.3 Cálculos do Índices de Espaços Livres de Uso Público (IELUP) e da Porcentagem de Espaço Livre de Uso Público (PELUP)......... 64

3.5 Levantamento da cobertura verde .............................. 64

3.5.1 Equipamentos, software e local de trabalho.................... 65

3.5.2 Obtenção das imagens ........................................ 65

3.5.2.1 Fotografia aérea ............................................ 65

3.5.2.2 Videografia ................................................... 66

3.5.3 Georreferenciamento das imagens .............................. 67

3.5.4 Classificação das imagens ...................................... 67

3.5.4.1 Amostras de treinamento ..................................... 67

3.5.4.2 Classificação supervisionada ................................. 67

3.5.4.3 Exatidão da classificação ....................................... 68

3.5.4.4 Mapa de cobertura do solo .................................... 68

3.5.5 Índice de Cobertura Vegetal em Áreas Urbanas (ICVAU) ....... 69

3.5.6 Índice de Verde por Habitante (IVH) ............................ 69

3.6 Índice de Qualidade do Espaço Verde com Função Ecológica (IQEVUe) 69

3.6.1 Distinção entre função ecológica e funções de lazer e estética.......................................................... 69

3.6.2 Parâmetros escolhidos para caracterizar a qualidade do verde urbano .................................................. 70

3.6.3 Obtenção do Índice de Qualidade do Espaço Verde Urbano com Função Ecológica (IQEVUe) ............................... 73

3.6.4 Cálculo do IQEVUe............................................ 73

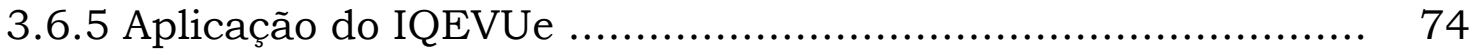


4 RESULTADOS E DISCUSSÃO

4.1 Arborização viária

4.1.1 Comparação entre censo, amostragem aleatória simples e amostragem estratificada na arborização viária de calçadas.

75

4.1.1.1 Comparação em função do número de árvores e arbustos... 75

4.1.1.2 Comparação em função das espécies de árvores e arbustos

4.2 Inventário quali-quantitativo do verde viário 98

4.2.1 Espaço verde das calçadas 98

4.2.1.1 Arborização nas calçadas 98

4.2.1.2 Piso das calçadas 106

4.2.2 Espaço verde de acompanhamento viário 108

4.3 Índice de Espaços Livres de Uso Público (IELUP) e Porcentagem de Espaço Livre de Uso Público (PELUP) ........... 109

4.3.1 Estudo dos espaços livres ............................................ 109

4.3.1.1 Formação do bairro Santa Cecília ................................. 109

4.3.1.2 Situação atual do bairro Santa Cecília ............................ 113

4.3.1.3 Identificação dos espaços livres de uso público ................ 116

4.3.2 Cálculo do Índice de Espaços Livres de Uso Público (IELUP) e da Porcentagem de Espaço Livre de Uso Público (PELUP) .....

4.4 Levantamento da cobertura verde .................................... 130

4.4.1 Imagem de estudo ................................................ 130

4.4.1.1 Fotografia aérea ........................................................ 130

4.4.1.2 Videografia ........................................................ 131

4.4.2 Classificação das imagens ........................................... 132

4.4.2.1 Fotografia aérea ................................................ 133

4.4.2.2 Videografia ..................................................... 136

4.4.3 Cálculo do Índice de Cobertura Vegetal em Áreas Urbanas (ICVAU) e do Índice de Verde por Habitante (IVH)................ 138 
4.5 Índice de Qualidade do Espaço Verde Urbano com Função Ecológica (IQEVUe) ...................................................................... 143

4.5.1 Obtenção do Índice de Qualidade do Espaço Verde Urbano com Função Ecológica (IQEVUe) ..................................... 143

4.5.1.1 Fórmula do IQEVUe................................................... 143

4.5.1.2 Sombreamento total de árvores de calçada ..................... 144

4.5.1.3 Hidrologia da área total........................................ 148

4.5.1.4 Fixação de Carbono da área total................................... 150

4.5.1.5 Atuação da temperatura na área total ........................... 151

4.5.2 Cálculo do IQEVUe............................................. 154

4.5.2.1 Sombreamento total das árvores de calçada do bairro Santa Cecília, Piracicaba - SP................................. 154

4.5.2.2 Hidrologia total do bairro Santa Cecília, Piracicaba - SP..... 155

4.5.2.3 Fixação de Carbono do bairro Santa Cecília, Piracicaba - SP... 155

4.5.2.4 Atuação da temperatura no bairro Santa Cecília, Piracicaba - SP.................................................. 156

4.5.2.5 Cálculo do IQEVUe do bairro Santa Cecília, Piracicaba SP, em 2003....................................................... 160

4.5.3 Aplicação do IQEVUe.................................................... 160

5 CONSIDERAÇÕES FINAIS................................................. 167

6 CONCLUSÕES........................................................ 170

REFERÊNCIAS BIBLIOGRÁFICAS.................................... 172

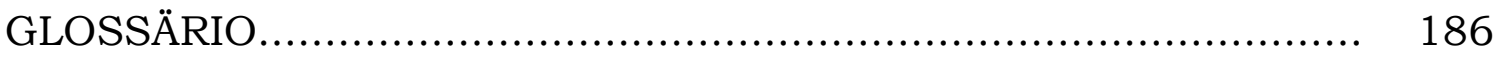




\section{LISTA DE FIGURAS}

Página

1 Localização do bairro Santa Cecília em Piracicaba - SP ............ 52

2 Bairro Santa Cecília, Piracicaba - SP: córrego e nascente; divisão em quarteirões e quarteirões sorteados para amostragem .................... 52

3 Porcentual de árvores, arbustos e palmeiras na arborização urbana do bairro Santa Cecília, Piracicaba - SP, em 2001........ 93

4 Porcentual de árvores, arbustos e palmeiras na arborização urbana do bairro Santa Cecília, Piracicaba - SP, em 2003........ 95

5 Índice de Diversidade de Shannon da arborização urbana avaliado no censo, nas amostragens aleatória simples e estratificada (estratos 1 a 4) do bairro Santa Cecília, Piracicaba - SP, em 2001.

96

6 Índice de Diversidade de Shannon da arborização urbana avaliado no censo, nas amostragens aleatória simples e estratificada (estratos 1 a 4) do bairro Santa Cecília, Piracicaba

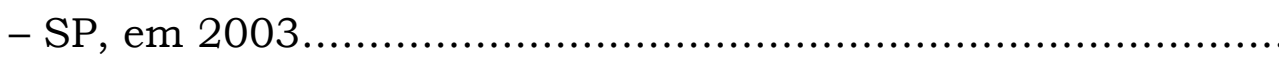

7 Aspectos gerais (vigor e poda) e estado fitossanitário (praga ou doença) das árvores de calçadas do bairro Santa Cecília, Piracicaba - SP, em 2001

8 Presença de bifurcação à altura do peito (BAP) e medida de circunferência à altura do peito (CAP) das árvores de calçada do bairro Santa Cecília, Piracicaba - SP, em 2001 
9 Presença de fiação sobre as calçadas e poda das plantas com e sem presença de fiação, das árvores de calçada do bairro Santa Cecília, Piracicaba - SP, em 2001

10 Presença de calçadas inadequadas e de recuo das residências na arborização das calçadas do bairro Santa Cecília, Piracicaba - SP, em 2001

11 Altura e diâmetro de copa das árvores de calçada do bairro Santa Cecília, Piracicaba - SP, em 2001 e 2003 .

12 Arborização de calçadas do bairro Santa Cecília, Piracicaba - SP. A Sibipiruna com poda adequada; B - Sibipiruna com poda drástica; C - plantio de Aroeira-salsa com espaçamento inadequado; D construções novas sem arborização; E - Pau-brasil com calçada verde; F - plantio de mudas de falsas-murtas

13 Fotografia aérea do bairro Santa Cecilia, Piracicaba - SP, em 1945 ..... 109

14 Fotografia aérea do bairro Santa Cecilia, Piracicaba - SP, em 1962 ..... 110

15 Fotografia aérea do bairro Santa Cecilia, Piracicaba - SP, em 1969 ..... 110

16 Fotografia aérea do bairro Santa Cecilia, Piracicaba - SP, em 1973 ....

17 Fotografia aérea do bairro Santa Cecilia, Piracicaba - SP, em 1978 .... 111

18 Fotografia aérea do bairro Santa Cecilia, Piracicaba - SP, em 1995 ....

19 Loteamentos, divisão em glebas, áreas particulares e espaços livres de uso público do bairro Santa Cecília, Piracicaba - SP .................. 114

20 Fotografia aérea do bairro Santa Cecilia, Piracicaba - SP, em 2000 ....... 130

21 Videografia do bairro Santa Cecília, Piracicaba - SP, em 2003.......... 131

22 Distribuição dos pontos amostrais para verificação da exatidão global do bairro Santa Cecília, Piracicaba - SP ...................... 
23 Modelo digital do bairro Santa Cecília, Piracicaba - SP, baseado em

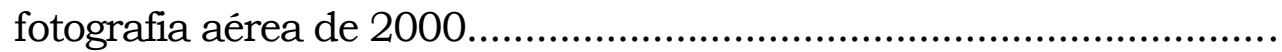

24 Modelo digital do bairro Santa Cecília, Piracicaba - SP, baseado em

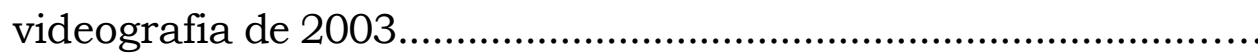

25 Relação entre dimensão de sombreamento $\left(\mathrm{S}_{\mathrm{i}}\right)$ e o produto da altura pelo diâmetro de copa das árvores de calçada do bairro Santa Cecília, Piracicaba - SP

26 Classes de temperatura de superficie obtidas por imagem de satélite do bairro Santo Cecília, Piracicaba - SP, em 2003 ...... 156

27 Termografia (imagem de satélite) comparada à imagem na videografia do bairro Santa Cecília, Piracicaba - SP, em 2003...... 


\section{LISTA DE TABELAS}

Página

1 Porcentual de cobertura do solo, de cobertura arbórea $\left(\mathrm{m}^{2}\right)$ por $100 \mathrm{~m}^{2}$ de área, de estoque (t/ha) e absorção (t/ha/ano) de Carbono para 4 cidades, na Coréia

2 Parâmetros avaliados no inventário qualitativo das árvores de rua do bairro Santa Cecília, Piracicaba - SP

3 Resultados do Censo, da Amostragem Aleatória Simples e da Amostragem Estratificada na arborização urbana do bairro Santa Cecília, Piracicaba - SP, em quarteirões definidos pela planta baixa e medidos na planta baixa, em 2001 ....................

4 Tamanho dos quarteirões definidos pela fotografia aérea, medidos na planta baixa e na videografia, presentes na arborização urbana do bairro Santa Cecília, Piracicaba - SP......

5 Resultados do Censo, da Amostragem Aleatória Simples e da Amostragem Estratificada na arborização urbana do bairro Santa Cecília, Piracicaba - SP, em quarteirões definidos pela fotografia aérea e medidos na planta baixa, em 2001............... $\quad 79$

6 Resultados do Censo, da Amostragem Aleatória Simples e da Amostragem Estratificada na arborização urbana do bairro Santa Cecília, Piracicaba - SP, em quarteirões definidos pela fotografia aérea e medidos na videografia, em 2001 ................... 
7 Resultados do Censo, da Amostragem Aleatória Simples e da Amostragem Estratificada na arborização urbana do bairro Santa Cecília, Piracicaba - SP, em quarteirões definidos pela fotografia aérea e medidos na planta baixa, em 2003 ...............

8 Resultados do Censo, da Amostragem Aleatória Simples e da Amostragem Estratificada na arborização urbana do bairro Santa Cecília, Piracicaba - SP, em quarteirões definidos pela fotografia aérea e medidos na videografia, em 2003

9 Espécies levantadas no censo e nas amostragens aleatória simples e estratificada, na arborização urbana do bairro Santa Cecília, Piracicaba - SP, em quarteirões definidos pela fotografia aérea, em 2001

10 Espécies levantadas no censo e nas amostragens aleatória simples e estratificada, na arborização urbana do bairro Santa Cecilia, Piracicaba - SP, em quarteirões definidos pela fotografia aérea, em 2003

11 Espécies levantadas na amostragem aleatória simples, na arborização urbana do bairro Santa Cecília, Piracicaba - SP, em quarteirões definidos pela videografia, em 2001 ...............

12 Espécies levantadas na amostragem aleatória simples, na arborização urbana do bairro Santa Cecília, Piracicaba - SP, em quarteirões definidos pela videografia, em 2003 ................

13 Área permeável nas calçadas dos quarteirões levantados no censo e na amostragem aleatória simples, na arborização urbana do bairro Santa Cecília, Piracicaba - SP, em 2003 ...... 106

14 Medida de áreas de acompanhamento viário, excluindo as calçadas do bairro Santa Cecília, Piracicaba - SP 108

15 Espaços livres de uso público presentes nos loteamentos e áreas particulares do bairro Santa Cecília, Piracicaba - SP, medidos na planta baixa, na fotografia aérea e na videografia..................... 
xvii

16 Tipos de Índice de Espaço Livre de Uso Público (IELUP) medidos na planta baixa, na fotografia aérea e na videografia do bairro Santa Cecília, Piracicaba - SP

17 Tipos de Porcentagem de Espaço Livre de Uso Público (PELUP) do bairro Santa Cecília, Piracicaba - SP.

18 Números de subclasses por tipo de cobertura do solo do bairro Santa Cecília, Piracicaba - SP

19 Classificação do tipo de cobertura do solo do bairro Santa Cecília, Piracicaba - SP, a partir de fotografia aérea, em 2000

20 Classificação do tipo de cobertura do solo do bairro Santa Cecília, Piracicaba - SP, a partir de videografia, em 2003 .......

21 Índice de Cobertura Vegetal em Áreas Urbanas (ICVAU) e Índice de Verde por Habitante (IVH) do bairro Santa Cecilia, Piracicaba - SP....

22 Área e porcentual de cobertura arbórea das calçadas do bairro Santa Cecília, Piracicaba - SP, por meio de levantamento em campo, fotografia aérea e videografia

23 Parâmetros avaliados para o cálculo do sombreamento total das árvores de calçada do bairro Santa Cecília, Piracicaba - SP........ 154

24 Parâmetros avaliados para o cálculo da hidrologia total do bairro Santa Cecília, Piracicaba - SP

25 Classes de temperatura de superficie e sua média (limite inferior e superior) na área total e média ponderada, obtidas por imagem de satélite de 25/02/2003 do bairro Santa Cecilia, Piracicaba - SP

26 Parâmetros avaliados para o cálculo da atuação da temperatura no bairro Santa Cecília, Piracicaba - SP.

27 Variações dos componentes do Índice de Qualidade do Espaço Verde Urbano com Função Ecológica (IQEVUe) do bairro Santa Cecília, Piracicaba - SP 


\section{QUALIDADE DO ESPAÇO VERDE URBANO: UMA PROPOSTA DE ÍNDICE DE AVALIAÇÃO}

Autor: IVAN ANDRÉ AVAREZ

Orientador: ANA MARIA LINER PEREIRA LIMA

\section{RESUMO}

O objetivo deste trabalho foi propor, entre os indices já existentes, um indice que avalie a qualidade da cobertura vegetal em relação à sua função ecológica, no meio urbano. Para a composição deste índice, compararam-se os métodos de amostragem aleatória simples e de amostragem estratificada de inventários da arborização de calçadas com o censo, com a finalidade de se escolher o melhor método de levantamento quali-quantitativo para árvores de calçada. Determinou-se o número de árvores por quilômetro, número total de árvores, Índice de Diversidade de Shannon (IDS) para árvores de calçada. Foram calculados o Índice de Espaços Livres de Uso Público (IELUP), a Porcentagem de Espaços Livres de Uso Público (PELUP), o Índice de Cobertura Vegetal em Áreas Urbanas (ICVAU) e o Índice de 
Verde por Habitante (IVH). Foram utilizadas planta baixa digital, fotografia aérea e videografia para mensurar as áreas ocupadas pela vegetação. A unidade de paisagem escolhida para estudo foi o bairro Santa Cecília em Piracicaba, Estado de São Paulo, Brasil, nos anos de 2000 a 2003. O levantamento amostral qualitativo das árvores de calçada foi feito por amostragem aleatória simples, escolhido, no trabalho, como o melhor método para inventariar árvores de rua. Considerando o ano de 2003, para a proposição do índice, os resultados obtidos foram: a) o IELUP variou de 11,42 a 41,62 $\mathrm{m}^{2} /$ hab (videografia); b) o PELUP variou de $1,52 \%$ a $2,89 \%$; c) o ICVAU foi de $25,76 \mathrm{~m}^{2}$ (forração + cobertura arbórea) e de $16,48 \mathrm{~m}^{2}$ (cobertura arbórea); d) o $\mathrm{IVH}$ foi de $101,96 \mathrm{~m}^{2} /$ hab (forração + cobertura arbórea) e de $65,21 \mathrm{~m}^{2} /$ hab (cobertura arbórea). Para a avaliação de espaços verdes urbanos foi feita discussão em função de obter-se um chamado "Índice de Qualidade do Espaço Verde Urbano" (IQEVU), particularizado para a função ecológica, então denominado "Índice de Qualidade do Espaço Verde Urbano com Função Ecológica" (IQEVUe). Os parâmetros para avaliação deste último índice foram: sombreamento, para árvores de calçadas; hidrologia, fixação de Carbono e influência de temperatura, para todos os espaços verdes. O IQEVUe mostrou-se adequado e coerente para mensurar os beneficios da vegetação em áreas urbanas, fornecendo subsídios para o planejamento e o manejo de cidades. 


\section{QUALITY OF URBAN GREEN SPACE: A PROPOSAL OF EVALUATION INDEX}

Author: IVAN ANDRÉ AVAREZ

Adviser: Prof. Dr. ANA MARIA LINER PEREIRA LIMA

\section{SUMMARY}

The aim of this work was to propose a new index, amongst other already known, that evaluates the quality of green coverage in relation to its ecological role in urban environment. To elaborate this index, simple random and stratified random sampling were compared with the census, in order to assess the best qualitative and quantitative method to do the tree inventory. A survey of sidewalk arborisation, as well as trees per kilometre, total number of trees and the Shannon Diversity Index (IDS) of sidewalk trees were evaluated. Amongst the studied indexes were the Index of Open Spaces for Public Use (IELUP), Percentage of Open Spaces for Public Use (PELUP), Index of Green Coverage for Urban Areas (ICVAU) and Index of Green per Inhabitant (IVH), by means of digital plan, aerial photography and videography for the areas covered by 
vegetation measurement. Santa Cecilia District in Piracicaba City, Sao Paulo State, Brazil, was the object of study from 2000 to 2003. The qualitative sampling survey of trees was carried out by simple random sampling, as found to be the most adequate to survey sidewalk trees. Data obtained for 2003, the year chosen to propose the new index, were: a) IELUP varied from 11.42 to $41.62 \mathrm{~m}^{2} /$ inhab, using videography; b) PELUP varied from $1.52 \%$ to $2.89 \%$; c) ICVAU was $25.76 \mathrm{~m}^{2}$ (coverage + tree canopy) and $16.48 \mathrm{~m}^{2}$ ( tree canopy ); d) IVH consisted of $101.96 \mathrm{~m}^{2} /$ hab (coverage + tree canopy) and $65.21 \mathrm{~m}^{2} /$ inhab (tree canopy). The index for the evaluation of green spaces, so named "Index for Quality of Green Urban Space" (IQEVU) was one of the subsidies to study and propose the "Index for Quality of Green Urban Space with Ecological Role" (IQEVUe). The parameters for evaluation of such index were the shading from sidewalk trees; hydrology, Carbon sequestration and temperature influence for all green space. In this study, the proposed IQEVUe seems to be adequate and coherent as an evaluation method for the benefits of urban vegetation, providing subsidies for the planning and management of cities. 


\section{INTRODUÇÃO}

A presença de vegetação nas cidades tem sido considerada um sinônimo de qualidade de vida. As cidades são ambientes alterados que possuem vegetação remanescente de áreas naturais ou que estão em áreas implantadas, que se apresenta de diferentes formas, tanto em áreas públicas (parques, jardins e praças), como em torno de córregos e rios ou em áreas privadas (residências e indústrias).

No planejamento urbano, é necessário realizar um bom diagnóstico da presença de vegetação, de modo a servir de subsídio para delinear um plano de ação para a implantação de espaços verdes e manejo da arborização existente. O verde é o elemento mais frágil nas cidades, uma vez que sofre diretamente os efeitos da ação antrópica, representada pelas pressões da urbanização e do adensamento populacional. Para garantir um mínimo de bem-estar à população, é importante quantificar os elementos presentes como verde nas urbes. Entretanto, o desafio que se apresenta é qualificá-los e relacioná-los entre si.

A qualidade do elemento vegetativo na malha urbana está relacionada com suas funções, que, basicamente, podem ser divididas em três tipos: de lazer, estética e ecológica. 
A abordagem da utilização do verde como lazer é importantíssima, mas ela não se restringe apenas a locais com presença de vegetação. De forma geral, esta presença na cidade, sempre estará relacionada à função ecológica, enquanto suas funções de lazer e estética nem sempre são contempladas.

A expressão "área verde" vem sendo aplicada como um caso particular de espaço livre urbano; todavia, em muitos casos, não se inclui a arborização viária para cálculo do índice de área verde, por ela estar em área impermeabilizada. Como aqui se pretende avaliar a importância da vegetação do ponto de vista de seus benefícios ecológicos, usar-se-á a expressão "espaço verde", sendo este um termo mais abrangente para o verde, dentro da cidade.

Existem diversos índices que procuram mensurar as áreas verdes, mas como não existe um padrão único convencionado, a comparação entre eles é delicada quando se pretende comparar diferentes locais. Usar Índice de Área Verde (IAV) como indicador de qualidade de vida, fundamentando-o apenas em quantidades, é um primeiro passo para se avaliar a questão ambiental. Limitar-se a isso, porém, implica em reducionismo.

A qualificação da arborização de ruas tem sido feita por meio de inventários; entretanto, eles não aparecem como componentes dos índices de área verde. Ainda não existem índices qualitativos que envolvam todo o verde da cidade. Mesmo com relação à quantificação da cobertura vegetal, ela deve ser ainda mais detalhada e relativizada, frente ao restante da área da unidade de paisagem urbana.

Apesar dos inúmeros fatores que se relacionam à ecologia urbana, inclusive os sociais e econômicos, uma pesquisa qualitativa pode parametrizar os principais aspectos da paisagem e avaliá-los com 
aproximações e métodos facilmente disponíveis, devido à democratização de meios computacionais e de sensoriamento remoto.

Neste trabalho, a questão da influência do verde na ecologia urbana está sendo analisada, não só sob o prisma da quantidade, mas, principalmente, do ponto de vista da qualidade. Na quantificação, como na qualificação do verde, é necessário simplificar os índices, permitindo que os resultados por eles fornecidos sejam usados pelos planejadores urbanos, para objetivos práticos e de forma particularizada para cada local. O geoprocessamento é aqui utilizado para estudar a cobertura vegetal. A partir deste estudo e com auxílio de outros métodos, quantifica-se o verde do ponto de vista ecológico para obter o Índice de Qualidade do Espaço Verde Urbano com Função Ecológica (IQEVUe).

Desta maneira, este trabalho tem como objetivo geral propor uma metodologia para avaliação da qualidade da cobertura vegetal em relação à sua função ecológica no meio urbano.

Os objetivos específicos são:

a) comparar métodos tradicionais de amostragem de inventários da arborização viária, com a finalidade de se utilizar o melhor método de levantamento quali-quantitativo para composição do IQEVUe;

b) obtenção do Índice de Espaços Livres de Uso Público (IELUP) e da Porcentagem de Espaço Livre de Uso Público (PELUP);

c) obtenção do Índice de Cobertura Vegetal em Áreas Urbanas (ICVAU) e do Índice de Verde por Habitante (IVH);

d) propor um novo índice, chamado de Índice de Qualidade do Espaço Verde Urbano (IQEVU), abordando especificamente 
um de seus componentes, o Índice de Qualidade do Espaço Verde Urbano com Função Ecológica (IQEVUe);

e) subsidiar a discussão da importância do uso de índices qualitativos em detrimento dos quantitativos, usados como parâmetros para avaliar a qualidade de vida;

f) mostrar a possibilidade de sugerir o índice proposto como ferramenta de diagnóstico para uso de órgãos gestores de planejamento urbano. 


\section{REVISÃO BIBLIOGRÁFICA}

\subsection{Levantamento da arborização viária}

As pesquisas na área de arborização urbana têm-se concentrado em levantamentos arbóreos como forma de subsídio para planos governamentais. Contudo, um levantamento arbóreo total é extremamente trabalhoso de ser feito. Para facilitar a observação da presença de árvores e de suas características, além de diminuir o tempo de pesquisa, existem métodos estatísticos que dão uma idéia do todo por meio de amostragem.

A quantificação e a qualificação da arborização urbana, obtida por meio de inventários, podem ser feitas por amostragem ou censo, sendo que esse último, por avaliar toda população, só se justifica para análise quantitativa (Nunes, 1992). A amostragem como instrumento de trabalho pode ser feita considerando os quarteirões e o número de árvores por quilômetro linear.

Uma vez conhecidos os limites e as características da população de árvores de rua e estabelecida a precisão desejada, a utilização de técnicas de amostragem constitui-se em procedimento de significativa eficiência para a avaliação de ruas. Utilizando "unidades amostrais retangulares" e "número de árvores por quilômetro de calçada como 
variáveis principais, procedimentos de amostragem aleatória demonstraram significativa eficiência para avaliação de arborização de ruas, conforme demonstraram vários trabalhos realizados (Milano, 1994; Michi \& Couto, 1996; Rachid \& Couto, 1999; Meneghetti, 2003).

A estratificação, utilizada como um tipo de amostragem, aumenta a precisão do levantamento quando se extrapola para a totalidade da população, uma vez que leva em consideração as peculiaridades do local. A população pode ser dividida em subpopulações que, isoladamente, sejam homogêneas. Essa divisão em camadas é chamada de estrato (Cochran, 1977).

Couto (1994) relata que a amostragem estratificada pode ser muito útil para o levantamento da arborização urbana; os estratos podem ser o bairro ou a densidade de árvores de ruas ou, ainda, um conjunto de quarteirões, a depender do fator que se opta para o agrupamento das unidades amostrais, na formação do estrato. A fim de se obter um resultado coerente com a realidade, os estratos devem possuir uma homogeneidade, de maneira que seus valores medidos não variem muito de uma unidade para outra. Dessa forma, pode-se obter uma estimativa precisa do valor médio de um estrato qualquer, empregando uma pequena amostra desse estrato. Segundo Cochran (1977), essas estimativas podem ser combinadas para constituírem uma estimativa precisa do conjunto da população.

A opção pelo tipo de amostragem a ser usada vai depender de um diagnóstico prévio do local onde o estudo será realizado. Segundo Milano et al. (1992), é necessário conhecer tanto a quantidade como a distribuição da vegetação no meio urbano, bem como sua situação em termos de características, destacando as qualitativas.

Primeiramente, é importante determinar os objetivos do inventário para, posteriormente, escolher entre as diferentes 
metodologias que apresentam diversos graus de precisão (Grey \& Deneke, 1978). Segundo Couto (1994), a determinação do tipo de amostragem mais adequada dependerá da homogeneidade da área. Rachid \& e Couto (1999) compararam dois métodos de amostragem para árvores de rua da cidade de São Carlos (SP) em função de identificar qual o mais eficiente. Dez porcento dos quarteirões que compunham a área de estudo foram sorteados para constituir a amostra, tanto no método casual simples, quanto em cada um dos estratos. O critério da escolha dos quarteirões para os estratos foi o nível sócio-econômico. Os dois métodos foram eficientes para fazer o levantamento, mas os autores indicam como preferencial, nesse caso, a amostragem casual simples por ser de mais fácil elaboração que a estratificação.

Meneghetti (2003) comparou a estratificação com a amostragem sistemática simples, em cinco bairros de Santos e concluiu, da mesma forma que os autores anteriores, que o ganho em precisão da estratificação não compensa a sua utilização, a não ser que se pretenda uma avaliação por bairro mais apurada.

Michi \& Couto (1996) obtiveram resultados que demonstraram que a amostragem com probabilidade proporcional ao tamanho das ruas é mais eficiente que a amostragem por conglomerados. Milano et al. (1992) também concluíram que maior número de parcelas de tamanhos menores foram mais eficientes que um menor número de parcelas maiores. Por outro lado, Rachid \& Couto (1999) verificaram que, nos métodos de amostragem aleatória simples e de amostragem estratificada, as unidades amostrais poderiam ser diretamente utilizadas nos quarteirões, independentemente de suas dimensões.

A maioria dos trabalhos de inventário de árvores de rua realizados no Brasil utilizaram como variável principal o número de árvores por quilômetro de calçada, sendo citados, como exemplos, os 
trabalhos de Lima et al. (1990) em Petrolina (PE), de Nunes (1992) em Apucarana (PR), de Lima (1993) em Piracicaba (SP), de Andrade (2002) em Campos do Jordão (SP). Alguns trabalhos utilizaram unidades amostrais de tamanho fixo e desprezaram aquelas unidades que possuíam baixa freqüência de arborização.

Rachid \& Couto (1999) e Meneghetti (2003) demonstraram que os métodos empregados não prescindem de informação sobre a quantidade de árvores existentes nas unidades amostrais e são usados sem censurar as unidades com baixo índice de arborização (Rachid \& Couto,1999; Meunier et al., 2001 \& Biondi, 1985). Foram excluídos do sistema de referência aqueles quarteirões destinados exclusivamente às áreas verdes.

Em todos os casos em que se comparou métodos de amostragem, não houve comparação com o censo das árvores do local. A precisão da amostragem pelas técnicas de estatística validam ou não os métodos, mas, se a comparação com o censo for feita, é possivel saber, com exatidão, o quanto de erro as amostragens apresentaram.

O levantamento do verde a ser realizado em áreas urbanas é complexo, porque há muitos fatores de variação das características dos componentes presentes no verde. Em áreas de mata, existem vários métodos utilizados para inventários florestais, enquanto que os métodos para amostragem de árvores presentes nas calçadas ainda não estão consagrados. Assim, ainda há necessidade de teste de métodos de amostragem da arborização para que se avalie qual o melhor método para se realizar o inventário urbano.

Ainda dentro do inventário urbano, para comparação entre os métodos de amostragem, pode ser considerado não só o número de espécies, mas, também, o tipo de espécie presente na área. Em inventários florestais, é comum utilizar-se o Índice de Diversidade 
Shannon (IDS) para avaliar a freqüência de uma espécie. Em árvores de ruas, vários inventários foram feitos com esse propósito, utilizando-se o IDS (Meneghetti, 2003).

A importância do uso de índices que mostrem a diversidade de espécies é permitir que se obtenha o máximo de informações referentes à variabilidade relativa. Shannon $\&$ Weaver $^{1}$, citados por Peet (1975), aplicaram esse conceito, chamado de "teoria da informação", para relativizar as informações, considerando que cada indivíduo (espécie) tem uma informação nova a ser acrescentada. O índice de Shannon usado como medida de diversidade foi proposto inicialmente por Margalef $^{2}$ (1957) citado por (Martins \& Santos, 1999).

Os modelos para descrição de diversidade eram inicialmente baseados em teorias matemáticas. Somente em 1957, os preceitos biológicos passaram a ser levados em consideração, na descrição da abundância de espécies (Martins \& Santos, 1999). Simpson ${ }^{3}$ (1949), citado por Martins \& Santos (1999), baseou a estimativa da diversidade em abundância de espécies de distribuição já definida, mas esse modelo não se ajusta a qualquer comunidade, o que dificulta a comparação entre populações. Os mesmos autores ainda citam que Simpson (1949) adaptou o modelo para parâmetros da amostra que dependeriam do tamanho da amostra. Essa proposta foi uma de utilização do índice para "comparar diferentes comunidades de modo independente do modelo de distribuição de abundância” e, segundo Simpson, o índice não era

${ }^{1}$ SHANNON, C.E. \& WEAVER, W. The mathematical theory of communication. University of Illinois Press, Urbana, 1949. $117 \mathrm{p}$.

2 MARgalef, R. La teoría de la información en ecologia. Memorias de la Real Academia de Ciencias y Artes de Barcelona, v. 32, p. 373-449, 1957.

${ }^{3}$ SIMPSON, E.H. Measurement of diversity. Nature, v. 163, p. 688, 1949. 
influenciado pelo tamanho da amostra, desde que ela fosse finita e constituída por dois ou mais indivíduos. O Índice de Concentração de Simpson baseia-se na equabilidade e expressa a probabilidade de dois indivíduos, tomados de uma comunidade de modo independente e aleatório, pertencerem a uma mesma espécie” (Martins \& Santos, 1999).

Pielou 4 (1975) citado por Martins \& Santos (1999) "considerou que, dentre os vários índices de diversidade até então propostos, H' de Shannon e $\mathrm{H}$ de Brillouin seriam os únicos com a propriedade aditiva. Isto é, as propriedades matemáticas desses índices permitiriam classificar os indivíduos da comunidade de várias maneiras independentes, calcular a diversidade parcial em cada categoria e expressar a diversidade total presente na comunidade como a soma das diversidades parciais. Se duas comunidades tivessem o mesmo número de espécies e se cada espécie tivesse a mesma abundância relativa em cada comunidade, então, qualquer medida de diversidade baseada nessas abundâncias relativas forneceria o mesmo valor para as duas comunidades. Mas, se em uma comunidade todas as espécies pertencessem a um mesmo gênero e, na outra, cada espécie pertencesse a um gênero diferente, intuitivamente se concluiria que a diversidade desta segunda comunidade deveria ser maior que a da primeira. Considerando categorias taxonômicas, como espécies, gêneros e famílias, seria possivel estabelecer a contribuição relativa de um gênero ou família para a diversidade total de cada comunidade comparada" (Martins \& Santos, 1999).

${ }^{4}$ PIELOU, E.C. Ecological diversity. New York: Wiley, 1975 


\subsection{Espaços livres e indices}

Espaço livre é um termo abrangente que inclui os termos área verde, parque urbano, praça, sistema de lazer, jardim, área de preservação permanente e áreas particulares existentes dentro dos limites urbanos. Neste trabalho, o termo "open space" é traduzido como espaço livre, conforme Lima et al. (1994). A sua presença na cidade é de vital importância para o bem-estar da população, exercendo função ecológica e estética.

Segundo Miller (1997), o primeiro critério para se estabelecer um espaço livre deveria ser o de um local onde a maioria da população teria acesso. Kürsten ${ }^{5}$ (1993), citado por Miller (1997), recomenda que todos os residentes em uma comunidade devem ter um contato com a natureza, andando, no máximo, cinco minutos a pé e sugere parques e espaços livres localizados a essa distância das residências. Existem classificações em função de categorias, de disponibilidade, de área por habitante e de tempo de acesso ao espaço livre. A mais conhecida no Brasil é a de Jantzen6 (1973), citado por Cavalheiro \& Del Picchia (1992), que define, por exemplo, Parque de Vizinhança, para crianças de 0 a 6 anos, como o mais próximo das residências, com uma distância mínima de $100 \mathrm{~m}$.

Essas classificações levam em consideração principalmente a questão do lazer, mas, quando se pretende abordar apenas a questão ecológica, existe uma grande dificuldade em se definir qual a distância adequada em relação à proximidade entre o verde e as residências.

${ }^{5}$ KÜRSTEN, E. Landscape ecology and urban forest corridors. Proc. Sixth Natl. Urban For. Conf. Washington, D.C.: Am. For. Assoc., p. 242-243, 1993.

6 JANTZEN, F. et al. Grünflächenbedarf Parkanlagen. 2 ed. Hamburg: SKGAL/RFA, 1973. 43p. 
Dever-se-ia considerar as mesmas distâncias recomendadas nos trabalhos para espaços livres, considerando as áreas verdes como caso particular de espaço livre? Nesse caso, deve levar-se em consideração as árvores de calçadas? $\mathrm{E}$ as árvores presentes dentro das residências? $\mathrm{E}$ as calçadas verdes? Como definir a unidade de paisagem? Até que distância ainda há influência da vegetação ao redor do morador?

Apesar da função primordial dos espaços livres nas cidades ser a recreação, conforme considera a maioria da literatura, vários autores ressaltam sua importância ecológica como área verde. Miller (1997) explica que cinturões verdes em volta de cidades e espaços livres podem contribuir para a conservação da biodiversidade. Essa preocupação de espaços livres interconectados surgiu desde 1860, nos EUA, com o desenho de Olmstead para parques de cidade interligados a áreas naturais (Smith, 1993).

Área verde é a denominação para o local onde a vegetação arbórea predomina (Lima et al., 1994). No entanto, existem vários locais na cidade, como canteiros centrais de avenidas, trevos e rotatórias, onde há predomínio de forração e que exercem papel ecológico e estético, mas que são considerados como pertencentes às áreas verdes.

Vários são os tipos de áreas verdes: faixas de acompanhamento, canteiros centrais, trevos e rotatórias do sistema viário, áreas de lazer, vários tipos de parques, cemitérios, hortas e áreas de preservação permanente - faixas em torno de rios, riachos e lagoas. Smith (1993) cita, em especial, os corredores verdes ou ecológicos ("greenways"), cuja função associa lazer e corredor de conservação diretamente orientado, às vezes dando ênfase à conservação, outras à recreação, mas freqüentemente incorporando os dois usos na mesma área.

Existem espaços livres não convencionais como cemitérios, jardins em torno de ferrovias, caminhos de servidão, faixas próximas à 
estradas (faixa "non-edicand") e canteiros centrais, corredores de passagem e áreas institucionais considerados por Platt (1994) como uma possibilidade de conter uma pequena variação em relação a paisagens naturais, mantendo vestígios de ambientes naturais.

A natureza dos espaços livres é a antítese do conceito primordial do paradigma de paisagem. Os planejadores das cidades preocupavamse antes em dominar a natureza. A cidade bonita, "The beaultiful city", era aquela que reduzia a natureza a um rol de arbustos, árvores e gramados, envolvendo pavimentos; não havia a preocupação da regeneração da natureza. Os espaços não planejados mais simples deveriam prover beneficios para as áreas adjacentes, em termos de microclima, drenagem e biodiversidade. Então, se um refúgio para estranhos insetos, ervas daninhas, flores selvagens, com talvez, árvores nativas, não pode reverter os danos ecológicos causados pela urbanização, pelo menos, podem amenizar os impactos do passado (Platt, 1994).

Beer et al. (2003) levantaram a questão de como as áreas verdes podem propiciar uma boa qualidade de vida em cidades compactas. O desenvolvimento de cidades compactas não precisa prescindir de áreas verdes, até mesmo dando oportunidades à criação de novos espaços. Freqüentemente, nos espaços verdes urbanos atuais não há mais que caminhos de gramas, sem multi-funcionalidade.

São necessárias soluções que integrem recreação e espaços que ofereçam biodiversidade, assim como a possibilidade de uso do solo para manejo e conservação da água (Beer et al., 2003)

Segundo Guzzo (1999), a existência de espaços livres urbanos expressa o significado de qualidade ambiental e de vida de uma cidade. O levantamento de sistemas de lazer que podem compor áreas verdes 
subsidia a realização de um planejamento adequado da ocupação do solo, em espaços urbanos.

O estabelecimento de medidas decisivas para a preservação de áreas verdes urbanas é facilitado quando se dispõem de dados que determinam a sua exata localização e a sua real superficie, permitindo futuros estudos ecológicos urbanos (Lombardo, 1985).

A ocupação do solo tem sido feita de maneira desordenada há muito tempo. Carrara (1992) ressalta que existe a necessidade de se revisar os padrões de ocupação do solo urbano, levando-se em consideração a possibilidade de desequilíbrio entre os elementos formadores do sistema urbano, o que poderia comprometer a qualidade de vida de seus habitantes. A vegetação representa papel fundamental nesse sistema, desempenhando funções associadas a aspectos sociais, estéticos, psicológicos e ecológicos, diminuindo, desta forma, os efeitos negativos do processo de urbanização (Foresti et al., 1987).

As intervenções na cidade, com intuito de melhorar a qualidade de vida, foram, inicialmente, voltadas para a melhoria das condições de sanidade, com Hausmann, em Paris e, no Brasil, no século XIX, com Saturnino Brito. Douglas (1987) ressalta que, no final do século XIX, foram iniciados os planejamentos de cidades-jardins e os subúrbiosjardins em torno de fábricas, na Inglaterra. A idéia desses projetos, a chamada "Letchworth Garden City Project", era a de gerar condições para diminuir a densidade de casas e introduzir jardins e linhas de árvores nas avenidas, o que fortaleceu a demanda por uma legislação de urbanismo e conduziu a "Lei de Urbanismo" decretada pelo Parlamento Britânico em 1909. Essa lei chamou a atenção para muitos assuntos relacionados ao tema da legislação e passou a incluir o termo espaço livre ("open space"), provisão de água, drenagem e disposição de esgoto. Ela estimulou a expansão de subúrbios de baixa densidade de casas 
com linhas de árvores destacadas e semi-destacadas nas ruas; a parte principal da cidade passava a ser o jardim.

Por muito tempo, os espaços livres nas cidade somente eram utilizados como áreas de lazer. A partir da década de 80 do século passado, os espaços livres assumiram um novo papel no clima urbano, na hidrologia, na vida selvagem e nos processos ecológicos; em resumo, passaram a ser uma nova forma de recursos urbanos (Platt, 1994).

No Reino Unido, entretanto, a expansão urbana tornou-se um dilema, ela não é desejável por causa de suas conseqüências ambientais negativas, incluindo a perda e a degradação da paisagem ao redor das cidades. Para se opor a esses efeitos negativos, as politicas recentes no Reino Unido requerem que 60 \% de moradias novas estejam localizadas em terra previamente ocupadas e que estas estejam em desuso. Além disso, espera-se que novas incorporações alcancem uma densidade mínima de 30 habitações por hectare. Contudo, a compactação adicional de cidades em si pode ter custos sociais e ambientais. A falta de áreas verdes de qualidade e a pobreza na qualidade ambiental global são as razões principais para que pessoas queiram mudar-se para os subúrbios, o que acaba por causar futuras expansões urbanas (Beer et al., 2003).

A criação de leis adequadas a cada local, para desmembramentos de solo e sua respectiva fiscalização, tornam-se de extrema valia, quando se fala em preservação do meio ambiente.

A adequação da quantidade de espaços livres para a população que dela usufrui é traduzida por meio de índices de área verde; porém, não há consenso na utilização de diversos índices (Cavalheiro \& Nucci, 1998).

A proposta metodológica de Nucci \& Cavalheiro (1996) foi um primeiro passo para se clarear a idéia sobre índices; nela, é proposto 
que a quantidade de vegetação em área urbana seja medida como um todo, denominado-a "mancha de verde", a partir de fotografia aérea.

Guzzo (1999) aperfeiçoou essa idéia inicial e utilizou três parâmetros para relacionar a presença de áreas verdes. O primeiro deles é Índice de Espaços Livres de Uso Público (IELUP) (expresso em $\mathrm{m}^{2} / \mathrm{hab}$ ), que é a quantidade de área de espaços livres urbanos de uso público, ou seja, as áreas cujo acesso das pessoas é livre. São somados nesse cálculo as áreas de praças, parques, sistemas de lazer e cemitérios. O segundo parâmetro é Índice de Cobertura Vegetal em Área Urbana (ICVAU) (expresso em porcentagem) que representa a proporção de área coberta com vegetação, em função da área total estudada. Ele abrange as áreas públicas e particulares. O Índice de Verde por Habitante (IVH) é o terceiro parâmetro (expresso em $\mathrm{m}^{2} / \mathrm{hab}$ ) e expressa a quantidade de cobertura vegetal dividido pelo número de habitantes do local.

Os índices citados acima servem como padrões de referência de qualidade de vida para uma população que habita um determinado local. Pesquisadores empregaram esses indices e realizaram cálculos para suas áreas de estudo, como é o caso de setores do município de Ribeirão Preto (SP) (Guzzo, 1999) e do Distrito de Santa Cecília, no município de São Paulo (SP) (Nucci, 1996).

Oliveira (1996) estudou o planejamento ambiental em São Carlos por meio da proposição de um Modelo de Classificação de Áreas Públicas e Áreas Verdes Públicas. O Modelo permitiu definir grupos específicos de Áreas Públicas, com base nas características estruturais, funcionais, utilitárias e legais das mesmas, de forma a possibilitar um diagnóstico sócio-ambiental baseado na Densidade Populacional (DP), no Porcentual de Áreas Verdes (PAV) e no Índice de Áreas Verdes (IAV), para todo o núcleo urbano. O Sistema de Informações Geográficas (SIG) 
IDRISI forneceu o suporte necessário para o desenvolvimento e para a aplicação de modelos operacionais específicos, enquanto o diagnóstico da arborização sugeriu estratégias para as áreas públicas e privadas, realçando aspectos de qualidade ambiental e de qualidade de vida. A proposta de implantação de novas áreas verdes foi avaliada por meio de prognóstico.

Douglas (1987) comenta que muitos dos problemas das cidades não são amenizados por falta de comunicação entre os cientistas, os planejadores e os tomadores de decisão. Ainda que se façam grandes projetos com adeqüabilidade ambiental e se tenha vontade politica de implantá-los, sem o envolvimento da população, qualquer estudo nessa área de melhoria das condições da cidade ficaria anulado.

Alguns planos sobre espaços verdes para grandes cidades desconsideram o papel multifuncional desses espaços. Muitas decisões sobre espaços verdes foram baseadas apenas em estética e considerações de custo. O que ainda está faltando, na maioria das cidades, é uma visão sobre o papel dos espaços verdes, uma compreensão de que eles formam uma estrutura verde que pode ser usada como um recurso em beneficio dos habitantes e para aumentar a sustentabilidade do meio (Hough ${ }^{7}$, 1989; Beer \& Higgins $^{8}$, 2000 citados por Beer et al., 2003).

O impacto do espaço verde sobre nossa saúde é cada vez mais reconhecido, mas este tema ainda precisa influenciar mais o urbanismo. Acrescente-se a isso a necessidade de mostrar a importância da

7 HOUGH, M. City form and Natural Processes. London: Routledge, 1989.

8 BEER, A. and Higgins, C. Environmental Planning for Site Development. London: Spon, 2000 
implementação desses espaços em escala local, em consonância com as condições ambientais, sustentáveis para vida urbana.

Beer et al. (2003) mostraram que a alta qualidade de espaços verdes urbanos resulta em lugares multifuncionais e que a presença desses espaços verdes exerce, portanto, várias funções:

a) apoio recreacional, experiencial e à necessidade de saúde de pessoas locais e de visitantes;

b) estímulo para que as pessoas desfrutem seu tempo de lazer no seu local de moradia, reduzindo o uso de veículos;

c) fornecimento de oportunidade para que moradores urbanos permaneçam em lugares relativamente quietos que não sejam as ruas da cidade;

d) geração de um sentimento de orgulho da comunidade em relação à sua localidade;

e) apoio ao desenvolvimento e à manutenção de biodiversidade em áreas urbanas;

f) apoio a manejo local d’água e aumento de qualidade de cursos de água;

g) fornecimento de área para deposição de dejetos biodegradáveis;

h) contribuição para a limpeza do ar, pela retirada de partículas por meio das copas de árvores e de arbustos;

i) redução do efeito de ilhas de calor urbanas;

j) aumento da atratividade econômica de uma cidade, já que áreas verdes atraentes podem influenciar os processos de decisão de empresários que buscam novas localizações para negócios, de investidores e de turistas ao escolher onde visitar.

Beer et al. (2003) também abordaram como o planejamento da estrutura verde deve ser feito. Para produzir planos de estrutura verde 
adequada, autoridades locais precisam analisar os seguintes aspectos nas áreas visadas:

a) qualidade de vida (experiência e atividade dos habitantes, incluindo necessidades recreacionais);

b) biodiversidade (o que precisa para preservar, mas também as oportunidades para aumentar a biodiversidade, utilizando o potencial de outras áreas de espaço verde);

c) engenharia de água (manejo de água de superficie para controlar enchente repentina e proteção de aqüiferos subterrâneos);

d) área de refugo (uso do potencial de espaços verdes para despejo de compostos biodegradáveis e para produção de biogás, onde as condições o permitam);

e) qualidade do ar e clima local (forma do solo e textura de superficie e seu impacto na qualidade de ar local).

Swanwick et al. (2003) consideraram as definições importantes para conhecer o conceito adequado. As expressões espaço verde ("green space”) e espaço livre ("open space”) são usadas livremente e de modo intercambiável. Aqui, tem-se usado espaço livre, seguindo as definições de Lima et al. (1994). Espaço verde ou área verde são termos relativamente novos que têm origem do movimento de conservação da natureza urbana. Na Inglaterra, a expressão "green space" é usada particularmente para enfatizar que o ambiente verde de áreas urbanas é mais que parques, jardins e campos de jogos. A expressão espaço livre freqüentemente tem sido usada com uma certa imprecisão, incluindo-se referência a alguma parte do ambiente externo, que é o espaço fora de construções em áreas urbanas. $O$ termo, na Inglaterra, tem um significado formal, ao menos no contexto do planejamento, porque ele é 
definido no "Town and Country Planning Act 1990 (Section 336)", como um jardim público, área pública de recreação ou um jardim de cemitério" (Swanwick et al., 2003). Com este significado, ele pode ser considerado como um sub-grupo de espaço verde. Certamente, aqueles responsáveis pelo planejamento e manejo de parques e espaços livres usam o termo espaço livre para se referir a acesso público, de responsabilidade da autoridade local.

Em Sheffield, Reino Unido, Swanwick et al. (2003) realizaram um trabalho para definir mais claramente esses termos. Eles sugerem que as áreas urbanas são feitas de ambientes construídos e de ambientes fora de construções. $\mathrm{O}$ ambiente externo inclui espaço verde e espaço cinza. O espaço verde é terra predominantemente com superficie não lacrada, permeável e leve (solo, grama, arbustos e árvores).

Espaço verde urbano é uma expressão usada para todas áreas de terra cobertas por essa definição de espaço verde, sejam elas de acesso público ou não e/ou de administração pública ou não. Ele inclui todas as áreas de parques e lazer, assim como outros espaços verdes especificamente direcionados para recreação e outras finalidades.

O espaço cinza é a terra que consiste predominantemente de superficies seladas, impermeáveis, duras, como concreto, pavimento ou asfalto. Espaço cinza pode ser dividido em espaço funcional que serve a uma proposta particular, prática, como avenidas, pátios, estacionamentos e outras superfícies duras associadas com diferentes tipos de construções, e espaços cívicos que são publicamente acessiveis, designados primariamente para finalidade pública, incluindo praças centrais, pátios, caminhos para pedestres e esplanadas.

Espaço livre é, entretanto, definido como aquela parte da área urbana que contribui para amenizar a vista, dando uma percepção positiva da paisagem urbana e/ou que tem a virtude de permitir acesso 
público. Então, ele combina espaço verde urbano com espaço público. Este conceito concorda, em termos gerais, com o de Espaço Verde Urbano. Swanwick et al. (2003) definem "open space" como "encopassing", isto é, uma mistura de espaço público (ou cívico) e espaço verde, onde espaços públicos são principalmente espaços duros como quadras, calçadas ("street frontages") e áreas pavimentadas.

\subsection{Geoprocessamento}

Apud Câmara et al. (1999), o termo Geoprocessamento denota a disciplina do conhecimento que utiliza técnicas matemáticas e computacionais para o tratamento da informação geográfica.

Os Sistemas de Informação Geográfica (SIG) são ferramentas computacionais para Geoprocessamento que permitem análises complexas, ao integrar dados de diversas fontes e ao criar bancos de dados georreferenciados (Câmara et al., 1999). Eles permitem identificar características com precisão geográfica.

A tecnologia do Geoprocessamento é de uso interdisciplinar, o que permite a convergência de diferentes disciplinas científicas para o estudo de fenômenos ambientais e urbanos. Apesar dessa aplicabilidade, os autores acima ressaltam que a interdisciplinaridade dos SIGs leva à redução dos conceitos de cada disciplina a algoritmos e estruturas de dados utilizados para armazenamento e tratamento dos dados geográficos.

Para se obter as imagens, utilizam-se sensores que não precisam estar em contato direto com o objeto a ser captado, mas que, captando sua energia, são capazes de convertê-la em imagens. Campbell (1987) 
destaca que a capacidade de coletar dados multiespectrais em diferentes escalas e diferentes épocas é um fator que torna a análise ambiental mais apurada.

Os sensores utilizados para se obter a imagem podem estar acoplados a satélites ou aviões. No caso de fotografia aérea, as imagens são obtidas por meio de uma câmera acoplada ao avião; na videografia, cenas são captadas pela câmara de vídeo e na imagem de satélites, os sensores presentes no satélite em órbita é que obtêm a imagem.

A interpretação da imagem é feita com o auxílio de softwares que utilizam informações digitais para a análise dos dados. Atualmente, não é preciso digitalizar as fotografias: as informações já são captadas digitalmente. Da mesma forma, a videografia que antes era feita analogicamente e depois transformada em informação digital, hoje utiliza tecnologia digital para captação.

Câmara \& Medeiros (1998) informam que a energia eletromagnética refletida ou emitida pela área da superficie terrestre é transformada em informação que é armazenada na forma de matriz. Cada elemento da imagem, denominado pixel, tem um valor proporcional à energia eletromagnética correspondente.

A análise das informações em forma de matrizes pode ser feita de maneira a classificá-las, criando-se um padrão. Novo (1992) ressalta que a subjetividade no processo de classificação é eliminada quando se classifica a imagem na forma digital e a referencia por meio de SIG.

A classificação pode ser supervisionada ou não, ou seja, relacionada a informações anteriores ou não. Na classificação não supervisionada a estratificação da imagem é feita pelo software utilizado estatisticamente sem a interferência de quem está analisando. A classificação supervisionada leva em consideração a amostragem em 
campo para a exatidão da classificação; o sistema computacional é treinado para reconhecer os padrões dos dados.

Lillesand \& Kiefer (1994) dividem em três etapas o método de classificação supervisionada: a) seleção das amostras de treinamento; b) classificação propriamente dita e c) produção de mapas temáticos e/ou tabelas que resumam os resultados da classificação.

$\mathrm{Na}$ classificação do objeto são definidos algoritmos que examinam a homogeneidade das amostras. Segundo Lillesand \& Kiefer (1994), os algoritmos mais comuns são o do paralelepípedo e da máxima verossimilhança. Para Valente (2001), o algoritmo de verossimilhança foi o mais eficiente para obtenção do mapa de uso e cobertura do solo da Bacia do Rio Corumbataí, em Piracicaba. Campbell (1987) discrimina como vantagem desse algoritmo o fato dele mostrar variação das classes espectrais; ele é capaz de classificar um pixel, computando a probabilidade deste pertencer a uma classe ou de ser desconhecido, dependendo dos valores de probabilidade estabelecidos.

\subsubsection{Fotografia aérea}

As fotografias aéreas permitem avaliar as informações da superficie terrestre no instante da tomada da foto, permitindo identificar e definir os alvos desejados, tanto da superficie terrestre, como deduzir os elementos e fenômenos subterrâneos.

A análise das fotografias é feita pela fotointerpretação, buscandose os critérios principais para a interpretação, no sentido de caracterizar os elementos de importância fundamental para a identificação dos fenômenos. Por exemplo: a tonalidade difere nos diferentes usos da terra; a textura auxilia na identificação dos diferentes usos e limites das 
propriedades; a forma auxilia na delimitação e identificação das propriedades.

A imagem de satélite não supera as fotografias aéreas convencionais no que diz respeito ao número de informações obtidas, pois sua escala, normalmente, é muito pequena. No entanto, é sempre necessário correlacionar e integrar os resultados de cada tipo de sensor, a fim de se obter resultados globais de forma eficiente e econômica.

Em áreas urbanas, Henke-Oliveira et al. (2000) utilizou o geoprocessamento e fotografias aéreas verticais para identificar a cobertura vegetal e o uso do solo de Luiz Antônio/SP, classificadas como áreas de vegetação arbórea/arbustiva iluminadas pelo sol; escurecidas pela sombra; áreas de vegetação herbácea densa e esparsa; solo exposto de diferentes texturas e cores, áreas edificadas e impermeabilizadas, como asfalto, telhado e outras superficies.

Várias são as aplicações para a fotogrametria em áreas urbanas e, entre elas, destaca-se o trabalho de Sekliziotis $^{9}$ (1980) citado por Whitford et al. (2001) que definiu tipos de cobertura de superficie para Merseyside (Reino Unido), a partir de fotografias aéreas por infravermelho. Posteriormente, Whitford et al. (2001) trabalharam com esses tipos de cobertura de superficie para que tivessem correspondência direta com a classificação requerida para indicadores de desempenho ecológico

9 SEKLIZIOTIS, S. A survey of urban open space using colour infra-red aeria photographs. Aston, 1980. Thesis (PhD) - University of Aston. 


\subsubsection{Videografia}

A videografia vem sendo utilizada como uma técnica de sensoriamento remoto que permite captar imagens e analisá-las por meio do computador. Pompermayer Neto (2002) encontrou relações entre os dados das imagens e tratamentos nutricionais em plantações de eucalipto utilizando os espectros azul, vermelho e infravermelho próximo, com câmera S-VHS.

Everitt et al. (1991) relataram que o que viabilizou o uso da videografia como sensor remoto foram os sistemas de gravação e o processamento das imagens por meio de computadores.

Pompermayer Neto (2002) destacou que o custo dos sistemas de vídeo é uma grande vantagem em relação a outros sensores, enquanto que Nixon et al. (1985) ressaltaram como vantagem a visualização imediata das imagens, permitindo a separação das faixas do espectro eletromagnético visivel de $400 \mathrm{~nm}$ a $700 \mathrm{~nm}$ e as faixas do infravermelho próximo (700nm a $1100 \mathrm{~nm}$ ). Couto et al. (2000) acrescentaram, ainda, como vantagens: a) a possibilidade de identificação e correção de problemas com rota e obtenção das imagens; b) a integração do sistema de videografia com GPS e com SIG e c) grande quantidade de imagens adquiridas.

A comparação de técnicas de sensoriamento remoto foi feita por Lowe et al. (1995), verificando que a videografia apresentou o mais baixo custo de captação e a maior eficiência do mapeamento da vegetação, utilizando filtros vermelho, azul e infravermelho próximo. 
Entre os problemas que a videografia apresentava, Um \& Wrigth (1999) ${ }^{10}$, citados por Pompermayer Neto (2002), havia a transição das imagens do sistema de vídeo analógico para o digital, fator limitante para a qualidade da imagem. Contudo, a tecnologia de câmeras digitais resolveu esse problema, permitindo para que a imagem obtida apresentasse uma boa qualidade.

As imagens obtidas por câmera de vídeo também podem ser georreferenciadas, como as fotos aéreas e as imagens de satélite. Os trabalhos de Pompermayer Neto (2002) e Everitt et al. (1991) foram georreferenciados.

A refletância do infravermelho próximo (700nm - 1350nm) é a que melhor reflete o limbo foliar. Segundo Shimabukuro (1996), essa faixa é adequada para classificação da vegetação, podendo, portanto, melhor diferenciar os tipos de vegetação: rasteira, arbórea, folha fina, folha grossa, vigor fenológico, valor de biomassa, entre outros.

\subsubsection{Imagem de satélite}

As imagens obtidas por meio de sensores de satélite captam energia eletromagnética por meio de diferentes bandas que percebem faixas de ondas distintas. É possível identificar diferenças de temperatura que demonstram a presença de ilhas de calor nas cidades, por meio dessas imagens.

O sensor Thematic Mapper (TM) do satélite Landsat 5 recobre a faixa do espectro refletido $(0,4 \mu \mathrm{m}$ a $2,5 \mu \mathrm{m})$ com 6 bandas, e outra banda

10 UM, J.S.; WRIGHT, R. The analog to digital transition and implications for operational use of airborne videography. Photogrammetric Engineering \& Remote Sensing, v. 65, n. 3, p. 269-275. 1999. 
cobre o espectro emitido ou termal $(10,4 \mu \mathrm{m}$ a $12,5 \mu \mathrm{m})$. A banda de número 6 serve para captação de energia termal.

Baptista (2002) constatou, a partir de imagens LANDSAT TM 5 para o Distrito Federal, um aumento médio da temperatura de $3{ }^{\circ} \mathrm{C}$ entre 1984 e 2001, numa proporção direta à ocupação urbana. Por outro lado, em um estudo histórico, esse autor verificou que, em área anteriormente sem ocupação, a temperatura variou de $18{ }^{\circ} \mathrm{C}$ para $28^{\circ} \mathrm{C}$.

Lombardo (1985) definiu um modelo computacional para o tratamento de imagens termais e estudou o fenômeno de ilhas de calor para a metrópole de São Paulo, chegando à conclusão que os dados do satélite NOAA-7 permitiram uma leitura da estratificação térmica horizontal e que, em agosto de 1981 , houve uma diferença de $10^{\circ} \mathrm{C}$ a mais no centro da cidade de São Paulo em comparação com a Serra da Cantareira.

Bias et al. (2003) adotaram o módulo termal do software IDRISI para identificação de ilha de calor no Distrito Federal, por meio da transformação das informações contidas nas imagens. Este módulo baseia-se nas funções de calibração dos detectores do sensor termal do satélite e converte os níveis de cinza da imagem em valores de temperatura, em graus centígrados.

Dados termais derivados de satélite correspondem à temperatura de superficie (Ts), para as quais as diferenças entre áreas rurais e urbanas são consideradas maiores durante o dia (Roth et al., 1989).

Temperatura de superficie, derivada de satélite, corresponde mais ao clima da camada de cobertura que pode ser descontínua entre estruturas urbanas. Assim, a representação acurada requer dados diferenciados, isto é, tamanhos de pixel menores. 
Carlson \& Boland ${ }^{11}$ (1978), citados por Nichol (1994), usando dados de três cidades de latitude média, encontraram que a Ts diurna e fluxo de superfície estão intimamente relacionados às características de cobertura do solo. No estudo, a heterogeneidade da superficie foi considerada um fator influente, mas ela, juntamente com a velocidade do vento, condutividade e outros fatores contribuíram com um erro de, somente, 1 a $2^{\circ} \mathrm{C}$ na estimativa da temperatura de chão. Tal fato ressalta a importância de superficies vegetadas no controle e na modificação do clima urbano, que retêm e transpiram umidade.

Entretanto, a superficie da forma como é captada pelo satélite é apenas uma porção da superficie ativa, particularmente em desenvolvimentos urbanos em franca expansão e isso pode representar, de forma realista, a superficie ativa. Esse efeito é acentuado em cidades tropicais, onde a alta insolação significa que as superficies horizontais, incluindo telhados e coberturas de árvores, podem ser significativamente mais quentes do que a temperatura média da superficie ativa (Ts) e a temperatura do ar. A Ts derivada de satélite pode não ser representativa e a superficie "vista" pode ser desproporcionalmente quente (Roth et al., 1989).

Observações derivadas de satélite, sobre a temperatura de superficie da Terra, são afetadas pela complexidade de interações entre radiação eletromagnética e a superficie da Terra e atmosfera, dentro do campo de visão dos sensores. Essas situações incluem emissividade diferencial dos tipos de cobertura de sol, a absorção, propriedades de

11 CARLSON, T.B.; BOLAND, F.E. Analysis of urban-rural canopy using surface heat flux temperature model. Journal of Applied Meteorology, v. 17, p. 998-1013, 1978. 
emitância do vapor de água e outros constituintes atmosféricos (Nichol, 1994).

Esses efeitos são particularmente pronunciados em cidades tropicais, devido à heterogeneidade da cobertura do solo urbano, em primeiro lugar e, em segundo lugar, ao clima tropical úmido, no qual a absorção e a emitância de radiação infravermelha pelo vapor de água de atmosfera pode ser responsável por cerca de $10^{\circ} \mathrm{C}$ de diferença entre temperaturas de superfície verdadeira e dados do satélite (Deschamps e Phulpan ${ }^{12}$, 1980, citado por Nichol, 1994).

Nichol (1994) relata que as superficies horizontais são mais ativas, com relação à irradiação, que superficies verticais. Então, há uma correspondência apoiada por outros resultados empíricos referentes à distribuição da biomassa relacionada à Ts.

A correspondência entre diminuição de temperatura e vegetação, nas áreas representadas por pixels, foram confirmadas por Nichol (1994).

\subsection{Ecologia Urbana}

\subsubsection{Climatologia urbana - calor}

Os efeitos mais deletérios da urbanização sobre o clima ocorrem durante os meses de verão e resultam das mudanças nos processos de troca de energia (Douglas, 1987). O aumento de energia em área

12 DESCHAMPS, P.Y.; PHULPIN, T. Atmospheric correction of infra-red measurements of sea surface temperature using channels at 3.7, 11 and $17 \mu \mathrm{m}$, Boundary Layer Meteorology, v. 18, p.131-143, 1980. 
urbanas, quando comparada a áreas menos construídas, ocorre especialmente durante os dias de verão, devido ao grande número de áreas construídas e de ruas que possuem alta retenção de calor e pequeno poder de reflexão. Mais calor é, portanto, acumulado durante o dia e re-irradiado à noite. Por outro lado, a perda de energia devida à evapotranspiração é diminuída pela redução na área vegetada. O resultado é a formação de uma "ilha de calor de verão", que torna a vida desconfortável para os habitantes, particularmente nos dias quentes, o que aumenta a necessidade de ar condicionado.

O conceito de escala é fundamental para entender as formas pelas quais os elementos da superficie urbana interagem com as camadas atmosféricas adjacentes. Uma construção individual, por exemplo, consiste de paredes e telhados, cada qual com um tempo de exposição à radiação solar, com uma troca de radiação de comprimento de onda longo líquida e com uma ventilação (Arnfield, 2000). Superfícies horizontais, no nível do solo, são uma colcha de retalhos de elementos, como espaços verdes irrigados e não-irrigados e áreas pavimentadas, com propriedades radiativas, termais, aerodinâmicas e de umidade deferentes (Kjelgren \& Montague, 1998), possuindo diferentes estoques de energia que geram contrastes nas características de superficie (temperatura de superficie), e levam a interações mútuas por trocas de radiação e advecção.

Em cada escala, as unidades possuirão balanços energéticos distintos que, em geral, representam mais do que a soma das médias de cada área levada em consideração, pois também incorporam as interações entre suas partes constitutivas. Principalmente, cada unidade interage por advecção com as adjacentes, na mesma categoria de escala (Ching et al., 1983). À medida que a escala aumenta, a variabilidade espacial parece ser reduzida, isto é, provavelmente haverá 
mais diferenças dentro de uma escala de bairro do que em uma escala de cidade.

As unidades morfológicas fundamentais dentro da colcha de retalho da cidade podem ser agregadas hierarquicamente. Paredes construídas e elementos situados entre construções, por exemplo, definem o "canyon" (abismo) urbano (UC).

Fundamental para o assunto de escalas é a distinção entre camada de cobertura urbana (urban canopy layer - UCL) e camada limite urbana (urban boundary layer - UBL). Esta distinção, originalmente aplicada a ilhas de calor urbano (urban hot island - UHI), feita por Oke (1976), tem sido o foco das pesquisas sobre climatologia urbana de todos os tipos. Os processos de circulação de ar e de troca de energia são controlados pela microescala e por características e processos locais especificos. A UBL acima do nível dos telhados, em contraste, é aquela parte da camada limite planetária cujas características são afetadas pela presença da superfície urbana (ou suas zonas de uso do solo) abaixo e é um fenômeno de escala local ou de mesoescala, controlado por processos que operam em escalas temporais e espaciais mais amplas. A distinção vai além de meras escalas, entretanto, ela reflete diferentes associações de processos.

Então, para escalas como um bairro, é importante estudar as trocas de energia entre a superfície dos telhados e as camadas imediatamente abaixo e as imediatamente acima.

\subsubsection{Diversidade de Ilhas de Calor Urbanas (UHI)}

Ilha de Calor Urbana (UHI) é um foco importante da pesquisa sobre clima, em áreas construídas. Entretanto, em vários trabalhos, há evidências de que há muitas UHIs, com diferentes características e controladas por diferentes associações de processos de troca de energia. 
Reconhece-se que há dois tipos distintos de Ilhas de Calor Urbanas (Oke, 1976), de acordo com diferentes tipos de medidas. Esses tipos são:

a) "ilha de calor da camada de cobertura urbana" que consiste no ar entre os elementos heterogêneos (principalmente coberturas com construções e árvores) e cujo limite superior pode ser visualizado como estando logo abaixo do nivel dos telhados. Esta camada, em grandes espaços abertos, pode ser totalmente inexistente; ela consiste de uma combinação de facetas horizontais e verticais, compreendida entre as construções, na qual áreas de telhado alternam com "canyons" urbanos, representados pelas ruas.

b) "ilha de calor da camada limite urbana", situada acima da primeira (a), cujas características são afetadas pela presença de uma área urbana em seu limite mais baixo, podendo flutuar no vento como uma pluma urbana.

Sensores termais remotos (termografia baseada em fotografia aérea ou imagem de satélite) permitem definição da UHI, principalmente da superfície do solo.

O levantamento termal remoto por satélite e as fotografias aéreas de grande altitude (Lombardo, 1985; Roth et al., 1989; Nichol, 1994) adicionaram conhecimento às teorias sobre UHI. Enquanto alguns estudos reportaram similaridades entre padrões espaciais de temperatura do ar e de temperatura de superficie, obtidas por medição à distância (Nichol, 1994), a maioria sugere diferenças significantes, quando se considera a hora do dia e a estação, de máximo desenvolvimento de UHI e de relação entre uso do solo e intensidade de UHI (Roth et al., 1989). Em particular, UHIs obtidas por medição remota por satélite, são geralmente mais fortes e exibem maior variabilidade espacial de dia, o oposto das UHIs de temperatura do ar. Roth et al. (1989) 
sugerem que essas diferenças têm suas origens na natureza da superficie urbana "vista" pelo sensor do satélite, especialmente aquela de um ângulo de elevação grande, dando uma visão plana da cidade.

Portanto, as UHIs são mais diversas que originalmente se supunha. A variedade será definida baseada nos aspectos do meio mensurado (ar, superficie, subsuperfície) e no sistema de percepção empregado. Cada uma possuirá sua própria climatologia e estará sujeita a influências causais variadas, mas é essencial que a natureza das medições usadas para definir as ilhas de calor seja apresentada nos resultados relatados e interpretada de forma correta. Do mesmo modo, um grande cuidado deve ser tomado ao comparar UHIs, se o meio monitorado e os métodos empregados forem diferentes.

Em regiões tropicais, diferenças entre verão e inverno provaram ser menos significantes que os contrastes entre estações secas e úmidas. Jauregui (1987), para a Cidade do México, encontrou um maior efeito de ilha de calor na estação seca que na úmida, uma conclusão consistente com a admitância termal maior nos ambientes, durante épocas de solos úmidos.

\subsubsection{Estocagem e fluxo de calor antropogênico no balanço energético urbano}

Oke (1988) sugere que, em escalas de cidades, para paisagens urbanas, uma abordagem útil é avaliar os fluxos de energia equivalentes em cada componente, através do topo de um volume imaginário da camada que se estende de uma profundidade, no substrato abaixo, na qual as trocas de energia são despreziveis na escala do tempo em consideração, até um nível à altura dos telhados, nas margens superiores da UCL. 
Por exemplo, o modelo de simulação de estoque de energia de Terjung \& Louie (1974) e Arnfield (2000) incorpora temperaturas de construção internas constantes, que refletem o investimento de energia antropogênica e espaços habitáveis refrescantes. Embora não apareçam como um item explícito no estoque de energia da superficie urbana, tais esquemas influenciam o clima externo, via fluxos de calor condutivo através das paredes das construções e telhados. O modelo não incorpora liberações de energia para o ambiente externo, como perdas de calor de motores de veículos, saída de calor de emissão de gases e de ares condicionados.

\subsubsection{Balanço de energia do meio urbano}

Asaeda \& Ca (1993) desenvolveram um modelo numérico e validado para investigar o papel do transporte de calor e de umidade, tanto dentro do solo exposto, quanto dentro do solo coberto por asfalto ou concreto. O impedimento do solo pela camada impermeável reduz o canal de evaporação, levando a maiores temperaturas de superficie; contrastes entre os balanços de energia de superficies dos topos dos telhados vegetados e os balanços de telhados convencionais de laje diminuem muito o aquecimento de superficie. Kjelgren \& Montague (1998) usaram um modelo de cobertura de camada dupla para avaliar o papel do tipo de superfície do solo (asfalto ou grama), mas nenhuma conclusão simples foi obtida, uma vez que as temperaturas de superfície mais altas do asfalto tanto aumentam o fluxo de onda longa no nível de cobertura, ainda que aumente a transpiração das plantas, quanto eleva as temperaturas das folhas, o que provoca o fechamento dos estômatos.

Em escalas ligeiramente maiores, estoques de energia de parques urbanos atraíram a atenção de Spronken-Smith \& Oke (1999). O resfriamento noturno de um parque mostrou que perdas de calor latente 
têm papel pequeno à noite, mas elas devem ser uma forma de estabelecer resfriamento relativo do parque à luz do sol.

Estoques de energia da época de verão de quatro cidades norteamericanas (Tucson, Sacramento, Chicago e Los Angeles), com diferentes morfologias e climas predominantes, foram comparadas por Grimmond \& Oke (1995). Embora o tamanho absoluto dos fluxos de energia totais médios variassem, as tendências dos fluxos diurnos eram quase iguais. Grimmond et al. (1996) exploraram o papel das árvores no estoque de energia suburbana e encontraram que, em valores absolutos, todos os fluxos, incluindo o de radiação líquida, eram aumentados num local com a maior cobertura de árvores.

\subsubsection{Hidrologia}

Hall (1984) resume do seguinte modo os passos da transformação da água da chuva em escoamento superficial:

a) proporção de volume de chuva que vai aparecer como escoamento superficial; este primeiro fator é inteiramente dependente da área que intercepta a água anteriormente à sua transformação em fluxo;

b) quantidade, velocidade e tempo de chuva;

c) tipos de drenos que irão captar diretamente a água da chuva.

A substituição de floresta e campo por estruturas mais impermeáveis, como construções e estradas, provoca os efeitos mais pronunciados da urbanização sobre a hidrologia, pois essas mudanças alteram vários aspectos que afetam o destino das precipitações. A menor área vegetada reduz a interceptação da chuva antes dela penetrar na superficie do solo. Da mesma forma, a evaporação da água é reduzida durante e depois da chuva, por haver menos área vegetada da qual a 
água possa ser evapotranspirada. Além disso, a infiltração da chuva no solo é também reduzida por ter menos área permeável. Assim, a maior parte da chuva é desviada pelo escoamento superficial para drenos, bueiros e cursos d'água. Os efeitos disso provocam o aumento da altura da correnteza e a probabilidade de ocorrerem enchentes e erosão das margens.

Ao interceptar e reter ou diminuir o fluxo da precipitação pluvial que chega ao solo, a arborização urbana realiza uma importante função nos processos hídricos urbanos. Sanders (1996) estimou que uma cobertura arbórea de $22 \%$ da área reduziu o escoamento em $7 \%$ e o aumento dessa cobertura para $29 \%$ reduziria o escoamento em cerca de $12 \%$. Segundo o mesmo autor, é mais importante, ainda, arborizar áreas onde o escoamento superficial é alto pela impermeabilidade do solo, porque muito escoamento ultrapassa a capacidade de drenagem urbana.

Um modelo matemático foi aplicado, por Grimmond et al.(1986), no subúrbio de Vancouver (Canadá), em períodos que vão de um dia a um ano, para analisar o papel da irrigação (principalmente de jardins, pelos proprietários), no balanço de água. Os autores sustentam a hipótese de que as altas velocidades de evaporação sejam mantidas pela advecção do calor em microescala, do ar seco vindo das superfícies impermeáveis para as vegetadas, e pela entrada de ar seco na UBL, por convecção penetrativa, aumentada pela rugosidade da superficie da cidade e por uma atmosfera instável.

Altas velocidades de evaporação são difíceis de explicar em localidades de cidade; o modelo de Grimmond et al. (1986) fornece um esquema teórico para analisar essas ocorrências, tais como as relacionadas às características particulares de áreas urbanas e à 
provisão de água encanada para o ambiente externo, por meio de irrigação, lavagem de ruas e similares.

\subsection{Qualidade da vegetação urbana}

Quando se trata das funções da vegetação nas cidades, várias são as abordagens feitas pelos pesquisadores, o que torna dificil separar uma função da outra. Aqui optou-se por separar as funções em:

Função de Lazer: são aquelas que satisfazem as necessidades de lazer, sejam elas fisicas, psicológicas ou sociais.

Função Ecológica: é aquela que melhora a qualidade ambiental com relação ao clima, à preservação e à proteção de recursos hídricos, geo-morfológicos, pedológicos, florísticos e faunísticos.

Função estética: é aquela que modela a estrutura urbana, integrando usos conflitantes, ocultando espaços indesejáveis, enfeitando cenários culturais e naturais, diversificando espaços monótonos, interligando massas de vegetação.

Em nenhum momento deve-se esquecer das importantíssimas funções de lazer e estética que os espaços verdes podem exercer, mas, para efeito do estudo aqui realizado, deu-se mais ênfase à função ecológica. 


\subsubsection{Função ecológica}

As funções ecológicas da vegetação, segundo Llandert (1982), podem ser consideradas como as funções reguladoras do meio ambiente e podem ser divididas em três grandes grupos:

a) relação clima-solo-vegetação;

b) composição atmosférica;

c) ruídos.

Existem muitos efeitos secundários das funções ecológicas da vegetação, mas, em todos os casos, a vegetação influi sobre o equilíbrio ambiental.

\subsubsection{Parâmetros para avaliação da função ecológica}

Withford et al. (2001) utilizaram quatro parâmetros para avaliar o desempenho ecológico dos espaços verdes: temperatura de superficie, hidrologia, absorção e fixação de Carbono e biodiversidade. O enfoque desses autores foi estudar as modificações que ocorriam no ambiente em conseqüência da urbanização.

O efeito amenizador, decorrente da presença de espaços verdes sobre o clima do meio em que cresce, pode ser percebido sobre a luminosidade, a temperatura, a umidade, a poluição, a velocidade do vento e o nivel de barulho. 


\subsubsection{Luminosidade e temperatura}

A cobertura vegetal, por meio das folhas, tem grande influência no clima, já que absorve de $15 \%$ a $35 \%$ da energia luminosa recebida durante as horas de insolação. Por outro lado, deixa passar entre 30\% e $50 \%$ da energia, refletindo o restante, ou seja, 30\% a 40\% (Landert, 1982).

A filtragem de radiação solar reflete-se na intensidade luminosa e, portanto, na temperatura, aceitando-se, como regra geral, que a vegetação tende a suavizar as temperaturas extremas.

O efeito da vegetação sobre o conforto térmico vai depender muito do meio ambiente que a circunda. As diferentes superficies apresentam variação em relação à absorção, reflexão (albedo) e transmissão de radiação solar. Bajwa (1995) mostrou, para o Golfo Pérsico, que a presença de vegetação foi controladora ou amenizadora das temperaturas nos interiores, reduzindo em até $65 \%$ o consumo de energia para resfriamento, em residências isoladas.

Bernartzky (1982) descreve que, em média, 60 a $75 \%$ da energia solar incidente na vegetação é consumida nos processos fisiológicos, porque as plantas não armazenam calor nas células, ocorrendo o equilíbrio por meio de trocas com o ar. O resfriamento e a filtração do ar, realizado pelas árvores, é maior do que aquela de gramados, pois a proporção entre volume de folhas e área ocupada é bem maior nas árvores.

O resfriamento realizado pela vegetação, em uma edificação, pode ser de duas formas:

a) direto - sombreamento redutor da conversão de energia radiante em calor sensível, que diminui a temperatura de superficie dos objetos sombreados; 
b) indireto - evapotranspiração das folhas que resfriam sua superficie e o ar adjacente, devido à troca de calor (Grimmond et al., 1986).

A primeira forma de resfriamento pode ser medida diretamente sobre a superficie que está sendo afetada, como é o caso das árvores sobre a calçada; a segunda, de maneira indireta, pela verificação do microclima da área de abrangência, como é o caso de espaços verdes não viário.

A sombra de uma árvore e seus efeitos sobre as superficies foram modelados por trabalhos como o de Sattler et al. (1987) que calcularam as inclinações do sol e a posição do sombreamento de uma árvore. Nesses trabalhos, foram definidos tipos de sombreamento diferentes (esférico, cilíndrico, cônico vertical ou de cone invertido e suas combinações). Porém, para tais modelos, foram necessárias informações sobre radiação incidente, transparência das árvores, entre outros dados, assim como, em outros trabalhos, considerou-se o tipo da espécie.

Canton et al. (1994) estudaram quatro espécies de árvores de clima temperado em relação às radiações global e difusa e descobriram que, em condições de inverno, a espécie que menos reteve a luz interceptou 19,2\% e, no verão, a que mais sombreou, interceptou 90,2\% da radiação global.

Silva et al. (1996) avaliaram o conforto térmico a partir da análise de índices de temperatura e de umidade relativa, de índices de temperatura do globo e de umidade, de carga térmica radiante, de temperatura efetiva e de índices de globo negro e de umidade das copas das espécies Sibipiruna (Caesalpinia peltophoroides), Tipuana (Tipuana tipu) e Sapucaia (Lecythis pisonis). Os autores mostraram que individuos de copa densa, baixa e de folhas largas não são recomendados, porque dificultam a ascensão do ar quente. Bueno (1998) comparou Sibipiruna, Jatobá (Hymenaea courbaril), Chuva de Ouro (Cassia fistula), Magnólia 
Amarela (Michelia champacca) e Ipê-roxo (Tabebuia impetiginosa) e encontrou um desempenho de $88,5 \%, 87,2 \%, 87,3 \%, 82,4 \%$ e $75,6 \%$ de atenuação pelo sombreamento, respectivamente. $\mathrm{O}$ mesmo autor ressalta que as variações relativas da temperatura ambiente e da temperatura de globo negro seguiram o mesmo padrão de comportamento da atenuação da radiação solar.

Conforme os trabalhos vistos anteriormente, de fato, por meio dos parâmetros de medidas externa às árvores, caracterizou-se o efeito causado por seu sombreamento. Contudo, à medida que se aumenta o número de parâmetros, dificulta-se a qualificação de maneira simples e objetiva dos benefícios da arborização urbana. Por outro lado, fatores intrínsecos às árvores, como características morfológicas, é que definem a área de abrangência da copa e, conseqüentemente, de seu sombreamento.

Vários autores avaliaram os efeitos da arborização urbana a partir de dados de diâmetro à altura do peito, altura da árvore, altura da copa, diâmetro da copa e área foliar das árvores (Huang et al., 1987; Simpson, 1998; Xiao et al., 1998). Simpson (1998), em especial, utilizou a altura e o diâmetro da copa das árvores para relacionar o sombreamento com uso de energia pelas residências, identificando uma economia de energia pela ação do sombreamento. Simpson \& McPherson (1996) mostraram, por meio de simulação de computador, que árvores plantadas na melhor direção para o hemisfério norte (duas na face oeste e uma na face leste), poderiam propiciar uma economia de até $23 \%$ de energia, nos horários de pico de consumo. 


\subsubsection{Umidade}

A presença de vegetação contribui de forma favorável para a conservação da umidade do solo, atenuando o aquecimento e detendo a irradiação. A evaporação embaixo da cobertura arbórea pode ser até dez vezes menor em campo aberto, informa Llandert (1982).

As plantas são elementos essenciais para combater a desertificação do clima urbano. Este efeito é causado pelo mecanismo conhecido como regulação higrométrica, que consiste em uma emissão de vapor de água através das superficies foliares, de três formas diferentes (Llandert, 1982), a saber:

a) evaporação física direta das chuvas;

b) transpiração fisiológica das plantas, inversamente proporcional ao grau higrométrico do ambiente;

c) clorovaporização do vapor de água durante a assimilação clorofílica de $\mathrm{CO}_{2}$ atmosférico, por meio da ação dos raios solares.

Esse efeito positivo da presença de vegetação deve-se, em boa medida, aos fenômenos de evapotranspiração descritos, que absorvem calorias, com o que se obtém uma diminuição da temperatura do microclima local nas horas de maior calor. Dessa forma, pode-se concluir que a elevação de temperatura que se dá nas cidades, em confronto com as temperaturas das áreas exteriores, é devida ao comportamento dos edificios, como massas rochosas que armazenam o calor e evaporam a umidade durante o dia, tornando, assim, a atmosfera urbana malsã e propiciando o aparecimento de enfermidades respiratórias.

As mudanças na captura de água de precipitação relacionadas à urbanização têm sido bem pesquisadas, o que levou ao desenvolvimento de muitos modelos de escoamento superficial de chuvas (Douglas, 1987; Hall, 1984). 
A maioria deles, porém, tende a ser muito sofisticada, com excesso de dados requeridos, impedindo que esses modelos possam ser usados facilmente. Os diferentes modelos têm elementos em comum, como a dependência do tipo de solo, do potencial de retenção de água e do porcentual de superficie impermeável, dentro da área de captação. Esta última variável tem sido indicada como crucial na determinação dos coeficientes de escoamento superficial de áreas de captação urbanas (Whitford, 2001) e deve ser um elemento crítico em qualquer modelo que investigue urbanização.

O modelo de Whitford (2001) utiliza o tipo de solo e o porcentual de cobertura de cada solo. Uma vez que o número de curva é conhecido, calcula-se o escoamento e, então, o coeficiente de escoamento para uma precipitação específica. Os tipos de cobertura de superficie classificados foram 16, de acordo com Sekliziotis ${ }^{5}$ (1980) citado por Withford (2001): construções; asfalto/concreto; superficies arquitetônicas; refugo; superficies líquidas; solo nu; gramado; relvado; mato; sub-arbustos; arbustos; árvores; canteiros de flores; hortaliças; cultura extensiva e outros. Essas 16 classes, foram resumidas por Withford (2001) em quatro tipos de cobertura: ambiente construído; espaço verde; cobertura arbórea e solo nu.

O tipo de solo, como parâmetro a ser utilizado para se identificar o desempenho ecológico da área em estudo é importante, mas, quando se relativizam áreas dentro de um sistema urbano, onde há muita alteração de camadas, até mesmo cortes ou aterros, o efeito do tipo de solo para estoque de água não fica claro. De outra forma, as áreas naturais dentro das áreas urbanas estarão sendo comparadas àquelas áreas pavimentadas onde o escoamento superficial é grande; os espaços verdes servem como área de captação, independentemente do tipo de solo que os constituem. 


\subsubsection{Composição do ar}

A ação purificadora das árvores pode ser resumida como em Llandert, 1982:

a) fixação de poeira e materiais residuais;

b) depuração bacteriana;

c) purificação por função clorofilica;

d) captação de gases tóxicos, já que um hectare de cobertura arbórea pode fixar cerca de 50ton de pó e partículas residuais.

Um dos maiores efeitos da urbanização é o aumento da emissão de Carbono por causa do aumento do uso de energia para o aquecimento e para o transporte. Rhode (1990), citado por Jo (2002), afirma que o $\mathrm{CO}_{2}$ é o gás que contribui com $50 \%$ do efeito estufa. As árvores são estoques diretos de Carbono e o absorvem ativamente, à medida que crescem.

O termo "absorção", aqui referido, é considerado o adequado, referindo-se ao estudo da fisiologia vegetal, ao contrário do termo "seqüestro", traduzido, por muitos, do termo em inglês "sequestration", agora tão em moda.

Os dados diretos de cobertura do solo não permitem calcular imediatamente a velocidade de emissão de Carbono; contudo, as taxas de armazenamento e de absorção de Carbono em árvores urbanas são muito mais fáceis de serem avaliadas, porque ambas são intimamente relacionadas às áreas de cobertura arbórea. Obviamente, há outros fatores que influem sobre a absorção de Carbono, como a idade fenológica das árvores: árvores novas têm menor biomassa e taxas de absorção mais altas que as mais velhas. Alguns estudos recentes, apesar disso, têm-se concentrado em árvores urbanas com distribuição 
heterogênea de idade (Rowtree \& Nowak, 1991; Jo \& McPherson, 1995; Johnson \& Gerhold, 2001; Withford, 2001 e Jo, 2002).

Jo (2002), medindo o impacto de espaços verdes em cidades na Coréia do Norte, encontrou os dados expressos na Tabela 1. O autor não identificou diferenças significativas para os dados de estoque e absorção de Carbono, nas cidades pesquisadas. Essas cidades variaram muito quanto à presença em ambientes construídos e em ambientes vegetados, mas diferiram muito pouco na quantidade de cobertura arbórea e no estoque de Carbono. Isso evidencia que a cobertura arbórea é a principal responsável pelo estoque e absorção de Carbono de uma dada área.

TABELA 1. Porcentual de cobertura do solo, de cobertura arbórea $\left(\mathrm{m}^{2}\right)$ por $100 \mathrm{~m}^{2}$ de área, de estoque (t/ha) e de absorção (t/ha/ano) de Carbono, para 4 cidades na Coréia

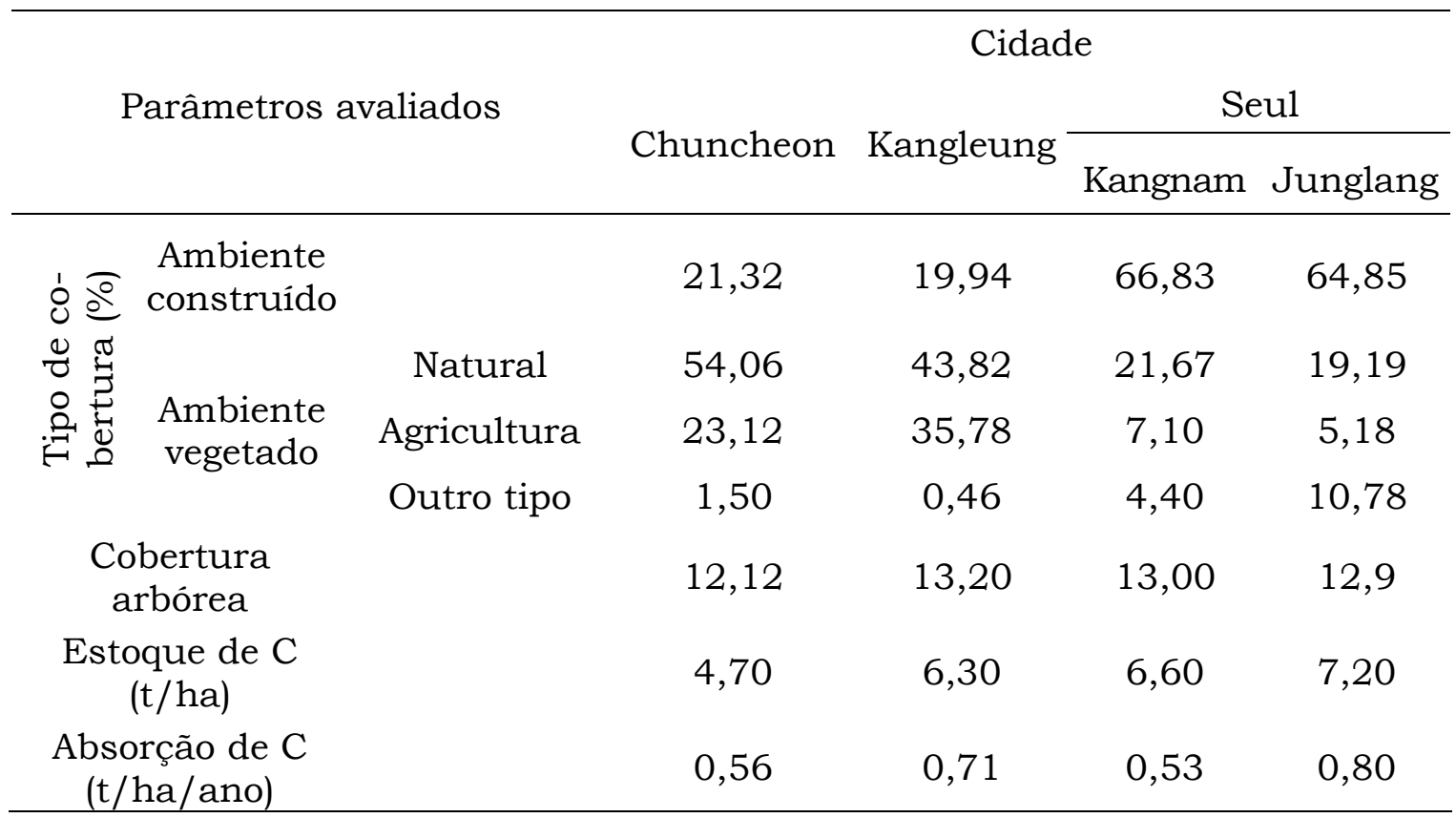

* modificado de Jo (2002) 
Johnson \& Gerhold (2001) relacionaram o estoque de Carbono com medidas de diâmetro à altura do peito (DAP), a partir de dados de densidade, de volume e de peso seco da madeira, encontrando uma relação significante. Contudo, ao se excluir a absorção e o estoque pelas folhas das árvores, como ele fez, coloca-se de lado um fator importante para árvores de rua, que é o fato delas constantemente sofrerem podas, o que modifica sua área de absorção, alterando sua capacidade de absorver e estocar Carbono.

Os modelos que retratam o estoque de Carbono, relacionando-o com a copa de árvores, foram eficazes, no sentido de prever as alterações sofridas pelo efeito do estresse das árvores por causa da urbanização. Withford (2001) concluiu que o estudo do armazenamento e da absorção de Carbono em árvores urbanas, calculados a partir das áreas de cobertura arbórea, é mais coerente, porque os dois fatores citados são intimamente relacionados à área de cobertura arbórea.

Rowntree \& Nowak (1991), em Chicago (EUA), criaram um método por meio do qual a fixação e a absorção anuais de Carbono por unidade de área de copa de árvores podem ser facilmente estimados. Withford (2001) utilizou esse método e estimou a distribuição média dos diâmetros das árvores em arborização urbana, segundo McPherson \& Rowntree (1986). O seu próximo passo foi calcular o número de árvores por unidade de área, utilizando a fórmula dada em Fleming ${ }^{13}$ (1988), citado por Whitford (2001), que calcula a relação entre diâmetro da árvore e área de copa para uma ampla gama de árvores, usando a taxa

13 FLEMING, L.E. Growth estimates of street trees in Central New Jersey. New Jersey, 1988. Thesis (M.S.) - University of New Jersey, Rutgers. 
de variação de extensão de copa de conífera, derivada de Winer at al.14 (1983), citado por Withford (2001), e assumindo que 75\% das árvores eram de copa de vários tipos e $25 \%$ coníferas. Após isso, Whitford calculou o total de peso fresco (abaixo e acima do solo), usando a equação de biomassa de Wenger ${ }^{15}$ (1984), citado por Whitford (2001). Finalmente, a fixação de Carbono foi calculada, estimando-se que os pesos secos de árvores variadas e coníferas eram $60 \%$ e $46 \%$ do peso fresco, respectivamente, e que a fixação do Carbono era $45 \%$ do total de peso seco da biomassa. Isso é resumido na seguinte fórmula simples, obtida por Whitford (2001):

Carbono estocado $\left(\right.$ ton $\left.\mathrm{ha}^{-1}\right)=1,063 \mathrm{X} \%$ cobertura arbórea

\subsubsection{Velocidade do vento}

O vento causa danos em algumas ocasiões, o que pode ser atenuado ou eliminado pelos espaços verdes, com uma distribuição adequada de seus elementos, conseguindo-se, dessa forma, um efeito positivo no meio ambiente urbano. Além dos efeitos benéficos em relação ao vento, diretamente produzidos pela simples presença das massas arbóreas, uma adequada composição dos volumes de vegetação pode incrementar esses efeitos benéficos, conseguindo criar áreas resguardadas nos espaços verdes urbanos, destinadas a oferecer calma e tranqüilidade.

Infelizmente, não se mede com facilidade o comportamento das composições urbanas ante o fenômeno eólico, principalmente, porque

14 WINER, A.M. et al.. Investigation of role of natural hydrocarbons on in photochemical smog formation on California air resources board, C.A. 1983

15 WENGER, K.F. Forestry handbook. New York: Whiley. 1984 
existem muitas variáveis que dificultam tecnicamente as avaliações, por ser a malha urbana uma "colcha de retalhos". Assim, Bueno (1998) considera que a velocidade do vento é um fator coadjuvante do sombreamento, mas, quanto o faz, é de dificil medição, por falta de equipamento adequado. Por outro lado, a temperatura de superficie e do ar representam a ação das correntes de vento presentes na área.

Vários autores utilizaram modelos complexos, partindo de Terjung \& Louie (1974), para investigar as correntes de ar dos ambientes climáticos das cidades, uma vez que eles dependem da estrutura da superfície da cidade e das condições do tempo. Arnfield (2000) apresentou esquema virtualmente idêntico para lidar com estoques de radiação e com escoamento de calor do substrato, mas com diferentes abordagens com relação à troca de turbulência dentro do espaço aéreo do "canyon".

Arnfield (2000) trabalhou um modelo de dispersão do vento com um esquema de parametrização, no qual o vento, no nível dos telhados, é calculado dentro dos componentes, através e para baixo do "canyon". Contudo, esse modelo exige uma grande quantidade de dados.

Portanto, ao se reduzirem os parâmetros de avaliação, de forma que eles representem a maior gama possível de situações, poder-se-á chegar a valores comparativos muito bons e confiáveis, do ponto de vista da realidade. 


\section{MATERIAL E MÉTODOS}

O trabalho foi realizado em 5 etapas, de forma a facilitar a compreensão da construção do pensamento e a obtenção do Índice de Qualidade do Espaço Verde Urbano com Função Ecológica (IQEVUe).

Em uma primeira etapa, foram necessárias repetição de protocolos e comprovação dos métodos de levantamento do verde viário urbano disponíveis, por meio de inventário quantitativo em campo (número e tipo de espécies), utilizando-se planta baixa digital, fotografia aérea e videografia para mensuração das áreas ocupadas pela vegetação.

Em seguida, numa segunda etapa, baseando-se no método de amostragem demonstrado como mais adequado à amostragem aleatória simples, fez-se o levantamento amostral qualitativo, de forma a caracterizar as árvores nas calçadas.

Depois, como terceira etapa, foi realizado um estudo pormenorizado dos espaços livres de uso público presentes na unidade de paisagem.

Uma vez levantadas as características do verde em campo, foi gerada uma classificação supervisionada por meio de técnicas de geoprocessamento, utilizando-se fotografia aérea e videografia e comprovação em campo: essa foi a quarta etapa do trabalho. 
A quinta e última etapa foi a discussão teórica sobre o Índice de Qualidade Ecológica do Verde com Função Ecológica (IQEVUe) e sobre os elementos que o compõem, seguida da demonstração de como este indice pode ser aplicado, utilizando-se, como dados de entrada, aqueles obtidos nas etapas precedentes.

\subsection{Local de estudo}

\subsubsection{Municipio de Piracicaba}

O município de Piracicaba localiza-se entre os paralelos 22030' e $23^{\circ} \mathrm{S}$ e entre os meridianos $47^{\circ} 30^{\prime}$ e $48^{\circ} 10^{\prime} \mathrm{W}$. A sede do município fica a 22॰42’30,9” S e 47॰38’01” W.

A área do município compreende $1416,5 \mathrm{~km}^{2}$.

A altitude de Piracicaba varia de $450 \mathrm{~m}$ a $750 \mathrm{~m}$, sendo que $61 \%$ do município está entre 500m e 600m (Ranzani, 1976).

O clima da região é classificado como sub-tropical úmido, com verão chuvoso (excedente hídrico $=259 \mathrm{~mm}$ ) e inverno seco (deficiência hídrica $=70 \mathrm{~mm}$ ). As temperaturas médias mensais anuais variam de $24,7^{\circ} \mathrm{C}$, no verão, a $17,9^{\circ} \mathrm{C}$, no inverno, sendo a média anual de $21,6^{\circ} \mathrm{C}$. As chuvas totalizam $1230 \mathrm{~mm}$ ao ano, concentrando-se entre outubro e março, quando ocorre, em média, $81 \%$ do total das precipitações $(1002 \mathrm{~mm})$. Entre abril e setembro, distribui-se o restante das chuvas (228mm). A evapotranspiração potencial anual é de $1042 \mathrm{~mm}$. 


\subsubsection{Definição da unidade básica de estudo}

O primeiro passo para a pesquisa da situação do local de estudo e de teste do IQEVUe foi a definição da unidade básica para comprovação da proposta metodológica do índice. Como, por definição, a proposta é de um índice que compreenda as funções ecológicas do verde voltadas para a qualidade de vida da população mais próxima, as questões locais são as mais relevantes. Portanto, a unidade de estudo que retrate, da melhor maneira possível, a influência do "Verde" sobre a população é o Bairro.

A definição da área de um bairro nem sempre é simples, uma vez que há as características históricas de sua formação e as divisões físicas. Aqui consideramos, para o estudo do local escolhido, a divisão oficial da prefeitura de Piracicaba.

Neste estudo, foi selecionado um bairro não muito longe do centro, com presença de verde nas mais diferentes condições - áreas verdes, áreas de preservação permanente e verde viário -, para tornar a análise qualitativa em questão a mais rica possivel. Por outro lado, outras características urbanísticas distintas, também importantes, foram consideradas: tais como áreas com construções (moradia, fábrica e edificio) e áreas sem construções (terrenos baldios).

\subsubsection{Bairro Santa Cecilia (Piracicaba - SP)}

O bairro Santa Cecília é localizado na zona leste do Município de Piracicaba, distando cerca de $3,5 \mathrm{~km}$ do centro (Figura 1). 


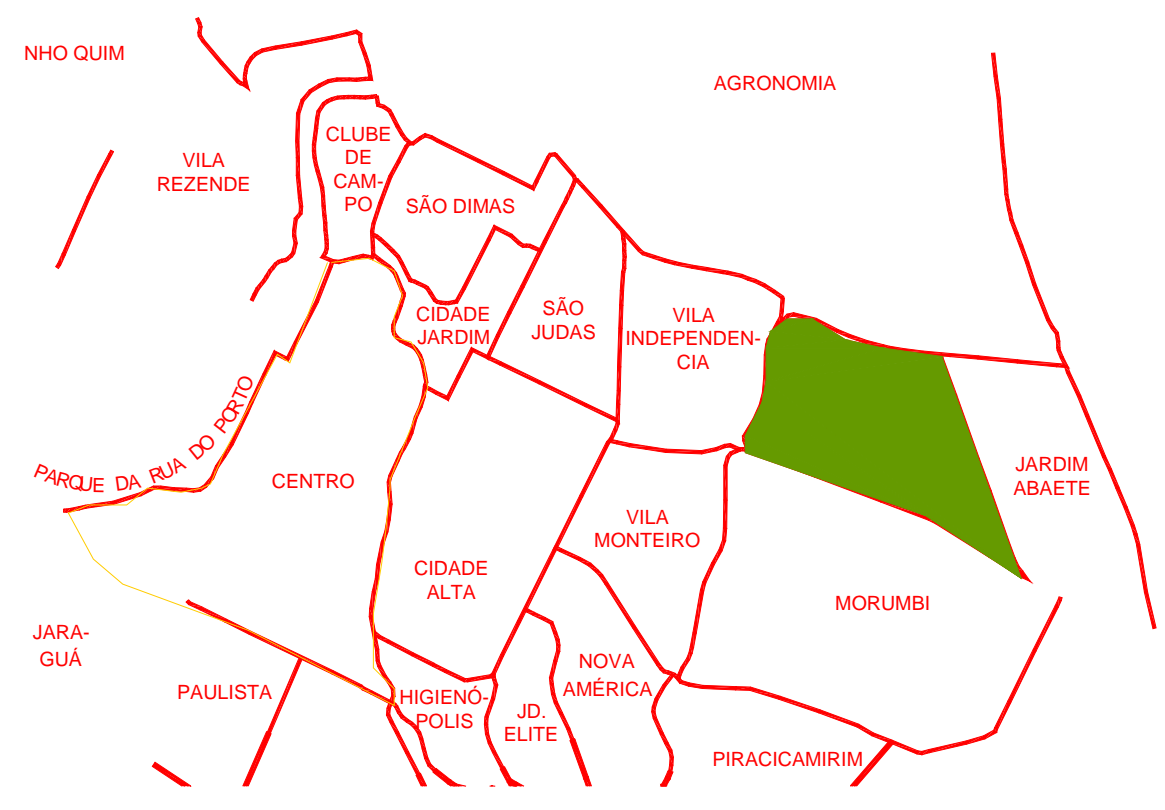

Figura 1 - Localização do bairro Sàñta Cecília em Piracicaba - SP

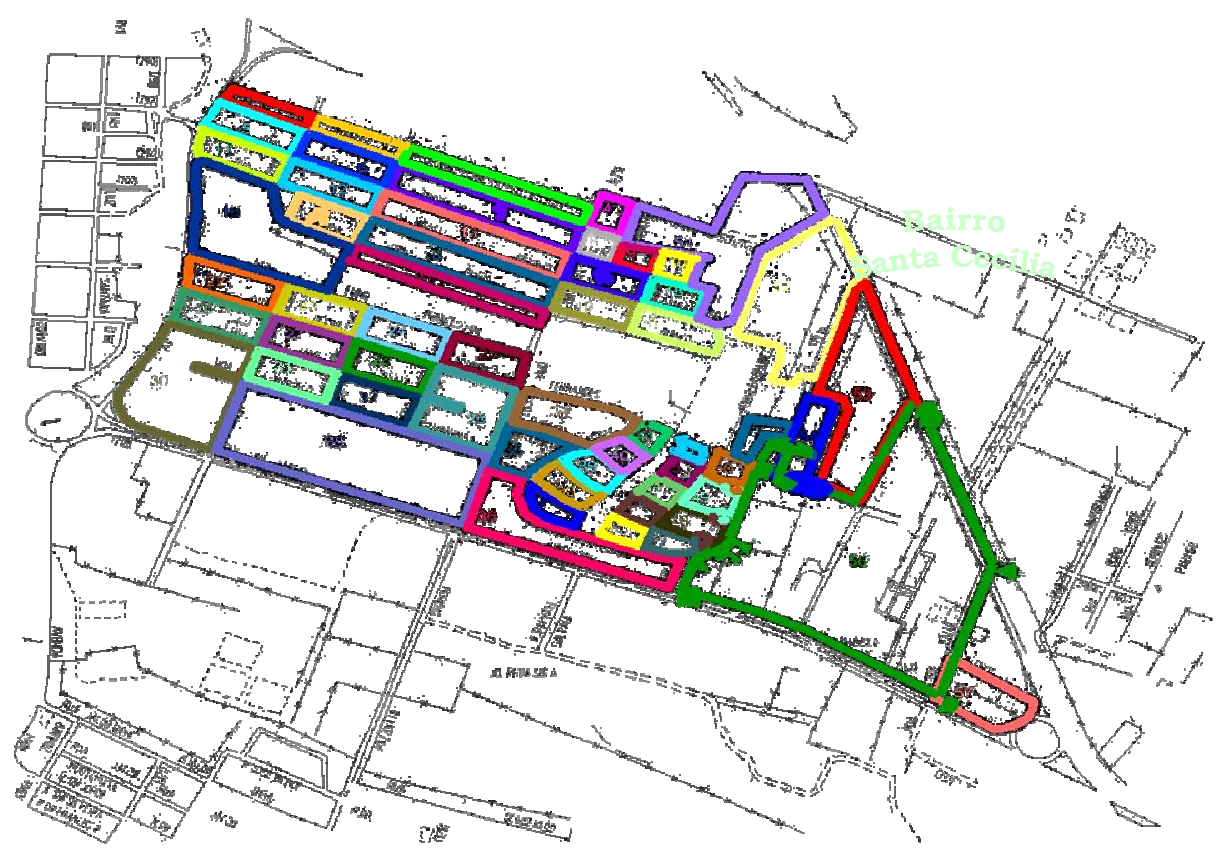

Figura 2 - Bairro Santa Cecília, Piracicaba - SP: córrego e nascente, divisão em quarteirões e quarteirões sorteados para amostragem 
O Santa Cecília é um bairro com população de classe média a classe média alta. Embora seja relativamente novo, a sua ocupação começou na segunda metade do século passado, por meio de chácaras. No início da década de 1970, iniciou-se, com maior intensidade, a urbanização do primeiro loteamento, o que se estende até os dias de hoje, por todo o bairro. Tal fato levou a uma diversidade das características urbanísticas, no que se refere ao nível sócio-econômico e à presença dos elementos vegetais. Essa heterogeneidade deve ser esmiuçada, uma vez que qualquer espaço a ser analisado apresentará características peculiares, decorrentes do local que ocupa.

\subsection{Arborização viária}

\subsubsection{Comparação entre censo, amostragem aleatória simples e amostragem estratificada, na arborização viária de calçadas}

A unidade amostral escolhida foi o quarteirão e o resultado foi expresso em árvore por quilometro linear de calçada. As variáveis estudadas foram o número de árvores por quilômetro linear (arv $/ \mathrm{km}) \mathrm{de}$ calçada, o número total de árvores no bairro e o tipo de espécie. A variável arv $/ \mathrm{km}$ foi calculada pela razão entre o número total de árvores existentes nas calçadas e o total de quilômetros de calçada.

Os quarteirões foram medidos por meio da planta baixa digital do município, fornecida pela prefeitura de Piracicaba (baseada na fotografia aérea de 1995), com a utilização do software Auto-Cad e por meio de videografia. A definição dos quarteirões foi inicialmente baseada na planta baixa da prefeitura. Feito o inventário inicial e constatada algumas divergências entre o mapa digital e a realidade em campo, 
definiu-se novamente a divisão dos quarteirões, com auxílio da fotografia aérea do ano de 2000 (Figura 2).

Alguns quarteirões não foram divididos de forma tradicional (4 lados), ou pela irregularidade das ruas, ou pela presença de áreas verdes. Nesses quarteirões, em que não há fechamento, somente foram medidas as calçadas pertencentes ao estudo da vegetação viária. A medida dos quarteirões de forma irregular, com formato curvo, foi feita por aproximação da curva em segmentos de reta, como em Rachid \& Couto (1999).

$\mathrm{O}$ número total de quarteirões encontrados no bairro, por meio da planta baixa e pela videografia, foi o mesmo, 57, excluindo aqueles quarteirões com apenas os espaços livres. A escolha dos quarteirões para a amostragem aleatória foi feita, inicialmente, sorteando-se 10 quarteirões, para depois, após os cálculos, obter-se um valor ideal de amostragem de 21 quarteirões. Então, sortearam-se mais 11 quarteirões, dos quais foram analisados 20 , pois um não possuía árvores.

Para a amostragem estratificada, foram escolhidos os mesmos 21 quarteirões, desconsiderando-se aquele que não tinha árvore, divididos em 4 estratos.

Quando se definiram novamente os quarteirões, o mesmo sorteio foi utilizado, mas a nova seleção agrupou dois quarteirões da divisão anterior, passando para 19 o número de quarteirões para as amostragens aleatória simples e estratificada.

O critério usado para a separação da amostragem em estratos foi a escolha de características que pudessem agrupar um número maior de quarteirões, no sentido de formar estratos homogêneos, sendo elas: a época de ocupação, a proximidade física dos quarteirões e o poder 
aquisitivo da população que ali residia. Os quarteirões escolhidos por estrato estão expostos na Figura 2.

A estimativa do número total de árvores do bairro (57 quarteirões) é importante para se ter uma idéia da dimensão do manejo que se pretende, porém, ela não mostra qual é a densidade da arborização viária. Os dados expressos em árvores por quilômetro de calçada dão uma noção mais clara da presença das árvores por espaço ocupado. Por outro lado, simplesmente avaliar a densidade não significa que a qualidade da arborização esteja sendo avaliada, pois muitas espécies poderiam não ser adequadas e/ou haver uma pequena diversidade. Portanto, avaliou-se, também, o Índice de Diversidade de Shannon (IDS) que representa a diversidade de espécies em relação ao número de exemplares.

Para o parâmetro "tipo de espécie" foram avaliados apenas os quarteirões definidos pela fotografia aérea de 2000, porque a planta baixa é baseada na fotografia aérea de 1995.

Os dados foram coletados nos anos 2001 e 2003.

\subsubsection{Amostragem aleatória simples}

O número de árvores por quilômetro de calçada foi estimado segundo Cochran (1977), que define razão populacional (R) como:

$$
\mathrm{R}=\frac{\mathrm{XT}}{\mathrm{YT}}
$$

$\mathrm{X}_{\mathrm{T}}=$ número de árvores existentes nos quarteirões

$\mathrm{Y}_{\mathrm{T}}=$ valor em quilômetros lineares de calçada dos quarteirões 
Dentro da área em estudo:

$\mathrm{n}=$ número de quarteirões selecionados para a amostra

$X_{\mathrm{i}}=$ valor da variável "número de·árvores"

$y_{\mathrm{i}}=$ valor da variável "total de quilômetros" do $i$-ésimo quarteirão sorteado.

Considerando os valores acima, o intervalo de 95\% de confiança para cada uma das razões populacionais é dado por:

$$
[r-2 s(r), r+2 s(r)]
$$

A razão amostral é representada da seguinte forma:

$$
r=\frac{\sum_{i=1}^{n} x_{i}}{\sum_{i=1}^{n} y_{i}}
$$

O coeficiente de variação é representado por:

$$
\begin{aligned}
& \frac{\sqrt{\mathrm{s}^{2}}}{\overline{\mathrm{X}}} \\
& \bar{X}=\text { média da amostras } \\
& \mathrm{s}^{2}=\text { variância, cuja fórmula é: }
\end{aligned}
$$




$$
s^{2}=\frac{1-f}{n \bar{y}^{2}(n-1)}\left(\sum_{i=1}^{n} x_{i}^{2}-2 r \sum x_{i} y_{i}+r^{2} \sum_{i=1}^{n} y_{i}^{2}\right)
$$

Sendo $\mathrm{N}$ o total de quarteirões da área de estudo, a razão amostral é representada por:

$$
f=\frac{n}{N}
$$

O valor médio da variável "total de quilômetros" é representado por:

$$
\bar{y}=\frac{\sum_{i=1}^{n} y_{i}}{n}
$$

O erro amostral é representado por:

$$
\operatorname{EA}(\%)=\frac{\mathrm{t} \cdot \mathrm{s} \overline{\mathrm{X}} \cdot 100}{\overline{\mathrm{X}}} \text {, sendo } \mathbf{t} \text { referente à variável com esta }
$$

denominação na tabela de Student.

\subsubsection{Amostragem estratificada}

A avaliação do número de árvores por quilômetro na amostragem estratificada foi estimada segundo Cochran (1977), por meio da razão populacional separada e proporcional. A razão amostral é a mesma em 
todos os estratos; denominada estratificação com repartição proporcional dos quarteirões por estrato, fornecendo uma amostragem auto-ponderada. A fórmula dessa razão é:

$$
\hat{\boldsymbol{R}}_{e s}=\frac{\left(\sum_{h=1}^{H} \frac{x_{h}}{y_{h}} Y_{h}\right)}{Y_{t}}
$$

Os componentes da fórmula são:

$$
X_{h}=\sum_{i=1}^{n_{h}} x_{i h} \text { e } y_{h}=\sum_{i=1}^{n_{h}} x_{i h}
$$

$X_{\text {ih }}=$ número de árvores existentes no $i$-ésimo quarteirão do $h$ ésimo estrato

$y_{\text {ih }}=$ valor de quilômetros lineares de calçada do quarteirão do $h$ ésimo estrato

O total de quilômetros de calçada no $h$-ésimo estrato é dado por:

$$
Y_{h}=\sum_{j=1}^{N_{h}} Y_{j h}
$$

$N_{h}=$ total de quarteirões do $h$-ésimo estrato

$Y_{j h}=$ total de quilômetros de calçada do j-ésimo quarteirão no $h$ ésimo estrato.

O total populacional da variável "quilômetros de calçada" é: 


$$
Y_{T}=\sum_{h=1}^{H} Y_{h}
$$

O coeficiente de variação, a razão amostral por estrato, o erro amostral para cada uma das razões populacionais por estrato são obtidos como na amostragem aleatória simples.

Foram arroladas também as espécies utilizadas na arborização desse bairro e, a partir desse levantamento, calculou-se o Índice de Diversidade de Shannon, que fornece a informação do número de espécies em relação ao número total de árvores. O Índice de Diversidade de Shannon (IDS) é calculado pela seguinte fórmula:

IDS $=-\Sigma \rho_{\mathrm{i}} \cdot \operatorname{Ln} \cdot \rho_{\mathrm{i}}$ onde $\rho_{1}$ é a proporção ao número de indivíduos da espécie em relação ao de número total de indivíduos.

Esses parâmetros avaliados na arborização viária servem como subsídios para a composição do Índice de Qualidade do Espaço Verde com função Ecológica (IQEVUe) e comparações com os inventários arbóreos tradicionalmente realizados.

\subsection{Inventário quali-quantitativo do espaço verde viário}

O verde viário do bairro Santa Cecília é composto pela arborização pertencente a um canteiro central, uma rotatória, três trevos viários, além das calçadas dos 57 quarteirões. A coleta de dados foi realizada em 2001 e 2003. 


\subsubsection{Espaço verde das calçadas}

Para o levantamento qualitativo da arborização nas calçadas, foram amostrados os mesmos 19 quarteirões, definidos pela videografia e sorteados para a amostragem aleatória simples.

\subsubsection{Arborização nas calçadas}

No ano de 2001, foram coletados os dados qualitativos e estes foram avaliados conforme expresso na Tabela 2.

Tabela 2. Parâmetros avaliados no inventário qualitativo das árvores de rua do bairro Santa Cecília, Piracicaba - SP

\begin{tabular}{|c|c|c|c|}
\hline Parâmetro avaliado & \multicolumn{3}{|c|}{ Classificação } \\
\hline Altura & até $5 \mathrm{~m}$ & 5 a $10 \mathrm{~m}$ & acima de $10 \mathrm{~m}$ \\
\hline Diâmetro & até 3m & 3 a $6 \mathrm{~m}$ & acima de $6 \mathrm{~m}$ \\
\hline Vigor & ruim & médio & bom \\
\hline Poda & sem & errada & correta \\
\hline Pragas & sem & provável & diagnosticada(s) \\
\hline Doenças & sem & presença provável & diagnosticada(s) \\
\hline $\mathrm{BAP} * 1$ & \multicolumn{2}{|l|}{ sem } & com \\
\hline $\mathrm{CAP} * 2$ & abaixo de $0,5 \mathrm{~m}$ & entre 0,5 e $1 \mathrm{~m}$ & acima de $1 \mathrm{~m}$ \\
\hline $\begin{array}{c}\text { Presença de fiação } \\
\text { sobre as calçadas }\end{array}$ & \multicolumn{2}{|l|}{ sem } & com \\
\hline Poda conforme a & \multicolumn{2}{|c|}{ em locais sem fiação } & em locais com fiação \\
\hline presença de fiação & podadas & podadas podadas & não podadas \\
\hline Calçada danificada & não & pouco & muito \\
\hline Recuo das edificações & sem & com & muito \\
\hline
\end{tabular}

*1 Bifurcação à altura do peito; ${ }^{* 2}$ Circunferência à altura do peito 
O vigor foi definido mediante análise visual, sendo os indivíduos mais depauperados classificados como "ruins" e os totalmente saudáveis, como "bons". Por outro lado, a calçada foi considerada pouco danificada pela árvore, se houvesse somente algumas rachaduras no piso, e muito danificada, caso houvesse risco aos pedestres.

No ano de 2003, nesses mesmos quarteirões, foram considerados apenas dois parâmetros para levantamento qualitativo: a altura e o diâmetro dos indivíduos arbóreos, uma vez que o objetivo do índice qualitativo (IQEVUe) é utilizar o mínimo possivel de parâmetros para estimar o máximo de características da arborização urbana.

\subsubsection{Piso das calçadas}

A permeabilidade das calçadas foi avaliada a partir da presença ou não de forração vegetal, as chamadas "calçadas verdes" ou "calçadas ecológicas". Para tal, avaliou-se o comprimento das calçadas dos quarteirões, definidos por fotografia aérea, medidos pela planta baixa e pela videografia, tanto para o censo, como para a amostragem aleatória simples. Considerou-se, para fazer o levantamento, três níveis de impermeabilização: (1) totalmente impermeável - sem forração; (2) medianamente permeável - cerca de $50 \%$ de forração e (3) totalmente permeável - 100\% de forração. O levantamento foi realizado também em 2001 e 2003, com dados referentes a todos os 57 quarteirões do bairro. O resultado foi expresso como a razão de área permeável das calçadas, em metros quadrados, pela área total de calçadas, em metros quadrados. 


\subsubsection{Espaço verde de acompanhamento viário}

Foram definidos dois tipos de canteiro central, porque, em 2000 (ano da fotografia aérea), o canteiro central da Avenida Cássio Pascoal Padovani apresentava-se diferente da conformação de 2003. As áreas foram medidas por meio de Auto-Cad 2000 (planta baixa), de aerofotogrametria (fotografia aérea de 2000) e pela videografia (cenas de 2003).

Para cada área do sistema viário observou-se o tipo de revestimento do solo, variando entre: solo exposto, solo com forração e solo impermeabilizado.

\section{4 Índice de Espaços Livres de Uso Público (IELUP) e Porcentagem de Espaço Livre de Uso Público (PELUP)}

A definição do IELUP e do PELUP foram baseadas nos trabalhos de Nucci \& Cavalheiro (1996) e Guzzo (1999).

\subsubsection{Estudo dos espaços livres de uso público}

\subsubsection{Situação do bairro Santa Cecília em 2003}

A caracterização da situação do bairro em 2003, composta por loteamentos e áreas particulares, baseou-se nos seguintes itens:

a) Planta baixa digital do município, obtida a partir da fotografia aérea de 1995;

b) Fotografias aéreas verticais de: 1945 (escala 1:25000), 1962 (escala 1:10000), 1969 (escala 1:8000), 1973 (escala 
1:8000), 1978 (escala 1:5000), 1995 (escala 1:25000) e 2000 (escala 1:30000);

c) Registros das áreas em cartório $\left(2^{\circ}\right.$ Cartório de Registro de Imóveis, Piracicaba - SP);

d) Informações cadastrais fornecidas pela Secretaria Municipal de Planejamento (SEMUPLAN) - bairro Santa Cecília (Setor $14)$;

e) Observações em campo;

f) Lei Municipal 2.643/85 que disciplina o parcelamento do solo urbano (Piracicaba, 1985);

g) Lei Complementar $n^{\circ} 144 / 2002$ que altera a Lei $n^{\circ}$ 2.643/85 (Piracicaba, 2002);

h) Lei Federal 4.771/65 que dispõe sobre o Código Florestal (Brasil, 1965);

i) Lei Federal 6.766/79 que dispõe sobre o uso e parcelamento do solo urbano (Brasil, 1979);

j) Lei Federal 9.785/99 que dispõe sobre o uso e parcelamento do solo urbano (Brasil, 1999).

\subsubsection{Identificação dos espaços livres de uso público}

O estudo dos espaços livres de uso público foi realizado com os mesmos parâmetros utilizados no item anterior para descrição da situação atual do bairro em 2003.

A partir dos subsídios dados pelos itens anteriores, calcularamse as áreas referentes a: sistema de lazer, área de preservação permanente (APP), APP invadida, área institucional construída e área institucional não construída. Os dados foram expressos por loteamento e por áreas particulares. Estudaram-se, também, os sistemas de lazer 
exigidos por lei, de que forma foram dispostos e se estão implantados corretamente ou não.

\subsubsection{Cálculos do Índice de Espaços Livres de Uso Público (IELUP) e da Porcentagem de Espaço Livre de Uso Público (PELUP)}

O cálculo do Índice de Espaço Livre de Uso Público (IELUP) foi feito a partir da identificação e da medição de cada área do sistema de espaços livres de uso público, por meio da modificação da planta baixa da prefeitura (baseada na fotografia aérea de 1995), modificada após a verificação em campo, e da observação da fotografia aérea de 2000 e da videografia de 2003. Esse cálculo foi apresentado conforme a classificação do tipo de espaço.

Os dados de tpos de IELUP foram expressos em metros quadrados por habitante, enquanto os tipos de PELUP foram expressos em porcentual de espaço livre de uso público em relação à área total do bairro.

O IELUP e o PELUP foram calculados para os dois anos de avaliação, para que se tivesse uma noção da evolução da disponibilidade dos espaços livres conforme o aumento da população. Para isso, utilizaram-se os censos de 1990 (IBGE, 1991) e de 2000 (IBGE, 2001).

\subsection{Levantamento da cobertura verde}

A cobertura verde do bairro foi levantada por meio da fotografia aérea e da videografia, para se obter o Índice de Cobertura Vegetal em Área Urbana (ICVAU) e o Índice de Verde 
por Habitante (IVH), baseado em Nucci (1996) e Guzzo (1999). A comparação entre os dois métodos para obtenção dos índices foi realizada para se ter uma idéia de diferentes métodos para obtenção da cobertura vegetal da área em estudo.

A cobertura vegetal dos espaços verdes foi verificada em espaço verde de arborização viária, espaço verde de espaços livres públicos e espaço verde de locais particulares.

\subsubsection{Equipamentos, software e local de trabalho}

O microcomputador utilizado foi um Pentium III $800 \mathrm{Mb}$ de memória RAM e HD de Gb, operando em plataforma Windows NT.

O sistema de Informações geográficas (SIG) utilizado foi o ERDAS IMAGINE versão 8.5 do fabricante Leica.

O software ADOBE PHOTOSHOP versão 7.0 auxiliou na montagem e corte das imagens.

Todo o trabalho de geoprocessamento foi realizado no Laboratório de Métodos Quantitativos do Departamento de Ciências Florestais da ESALQ/USP.

\subsubsection{Obtenção das imagens}

\subsubsection{Fotografia aérea}

As fotografias aéreas verticais, utilizadas neste trabalho, foram adquiridas da empresa BASE, do vôo de junho de 2000 sobre a cidade de Piracicaba, com uma escala de 1:30.000.

As fotografias foram fornecidas pela empresa, já digitalizadas. 
A área exata de estudo foi definida pelo recorte da imagem digital da cidade de Piracicaba, por meio do programa de computador Adobe Photoshop, aproveitando que o mosaico para a cidade já havia sido montado no mesmo programa.

\subsubsection{Videografia}

As cenas obtidas para realização da videografia foram feitas com a câmera de vídeo digital Duncantech MS-3100, fixada em uma abertura no piso do avião. O sobrevôo na área de estudo foi feito em um avião CESSNA modelo 180, no dia 19 de agosto de 2.003, das $11: 50 \mathrm{~h}$ às $12: 20 \mathrm{~h}$, a uma altitude de $2.300 \mathrm{~m}$ do nível do mar e $1.700 \mathrm{~m}$ do nível do solo. No horário do vôo, o céu apresentava ótimas condições de visibilidade e nenhuma nuvem.

A câmera, durante o vôo, foi ligada a um microcomputador que armazenava as imagens digitais por meio da placa de captura de vídeo e a um monitor, para que fosse possivel a visualização da cena da área em estudo, que se pretendia obter. Foi necessário traçar três linhas de sobrevôo na área.

A câmera possui sensores CCD que captam o infravermelho próximo.

As imagens foram capturadas com um tamanho de pixel que resultou numa resolução espacial de aproximadamente $1 \mathrm{~m}$.

Como se obteve, durante o vôo, 55 cenas compondo a área, foi necessário montar um mosaico para que se obtivesse a área toda. Foram escolhidas as melhores cenas, somando um total de 24, para montagem do mosaico no programa computacional Adobe Photoshop. 


\subsubsection{Georreferenciamento das imagens}

Para georreferenciamento das imagens obtidas pela fotografia aérea e pela videografia, foram tomadas as coordenadas no campo, com um receptor GPS (Global Positional System).

Após a obtenção das coordenadas, elas foram transformadas de coordenadas geográficas para o sistema métrico UTM, utilizado pelo software Erdas Imagine, para referenciamento das imagens.

\subsubsection{Classificação das imagens}

A classificação das imagens, tanto as obtidas das fotografias aéreas, como as da videografia, foi realizada a partir de verificações preliminares, em campo. Posteriormente foi feita a classificação supervisionada, isto é, as atribuições às imagens em função das visitas realizadas ao campo.

\subsubsection{Amostras de treinamento}

As amostras de treinamento, para se definir o tipo de subclasse, foram delineadas por polígonos, em tela, sobre áreas que representavam o tipo de cobertura de solo definida pela ida à área de estudo.

\subsubsection{Classificação supervisionada}

Para a classificação supervisionada, empregou-se o algoritmo de máxima verossimilhança (Jensen, 1996). 


\subsubsection{Exatidão da classificação}

Para se ter certeza de que a classificação realizada foi coerente com a realidade, calculou-se a Exatidão Global (EG) por meio da fórmula (Congalton et al., 1983):

$$
\mathrm{EG}=\frac{\mathrm{A}}{\mathrm{N}}
$$

$$
\begin{aligned}
& A=\text { acerto geral (pontos amostrais com acerto) } \\
& \mathrm{N}=\text { número de pontos amostrais, sendo: } \\
& \mathrm{N}=\frac{\mathrm{Z}^{2} \times \mathrm{p} \times \mathrm{q}}{\mathrm{e}^{2}} \\
& \mathrm{Z}=\text { valor da tabela } \\
& \mathrm{p}=\text { porcentual de exatidão esperado } \\
& \mathrm{q}=100-\mathrm{p} \\
& \mathrm{e}=\text { erro permissivel }
\end{aligned}
$$

Para o cálculo, a exatidão esperada foi de $85 \%$ e o erro admissivel, de 5\%. O número de pontos amostrais foi distribuído ao acaso, por meio da amostragem estratificada e essa distribuição foi feita pelo SIG (Valente, 2001).

\subsubsection{Mapa de cobertura do solo}

A análise da imagem foi realizada pelo software ERDAS e gerou um mapa digital que expressou as diferentes coberturas de 
solo. O mapa foi criado tanto a partir da fotografia aérea, quanto da videografia.

\subsection{5 Índice de Cobertura Vegetal em Áreas Urbanas (ICVAU)}

O ICVAU foi medido em porcentual, sendo ele a proporção das áreas cobertas com vegetação em função da área total estudada, tendo abrangido as áreas públicas e particulares.

\subsection{6 Índice de Verde por Habitante (IVH)}

O Índice de Verde foi medido em metros quadrados por habitante (IVH), sendo a quantidade de cobertura vegetal dividida pelo número de habitantes do local.

\section{6 Índice de Qualidade do Espaço Verde Urbano com Função Ecológica (IQEVUe)}

\subsubsection{Distinção entre função ecológica e funções de lazer e estética \\ O estudo das funções da vegetação no meio urbano levou em consideração que toda área, por mais pobre em vegetação que seja, exerce pelo menos um mínimo de função ecológica. Portanto, considerou-se a função ecológica como primordial para a avaliação qualitativa do verde, sem considerar menos importante as outras funções.}




\subsubsection{Parâmetros escolhidos para caracterizar a qualidade do verde urbano}

A obtenção de um índice de qualificação do verde utilizou a quantificação aliada à avaliação dos benefícios propiciados pela vegetação ao ambiente.

Os benefícios selecionados para serem avaliados como principais foram:

a) Verde viário: sombreamento (somente para árvores de calçada), temperatura, hidrologia e fixação de Carbono;

b) Outros espaços verdes: temperatura, hidrologia e fixação de Carbono.

O sombreamento somente foi considerado para calçadas, por influenciar diretamente sobre o conforto térmico das residências próximas, assim como sobre a radiação incidente. Quanto aos outros espaços, o efeito do sombreamento é global e está implícito no efeito sobre a temperatura.

Para caracterizar o sombreamento, consideram-se os dados de altura e diâmetro médios das árvores do sistema viário como forma de abordagem, para cálculo de atenuações de temperatura e de radiação solar.

Para medir o efeito do sombreamento, deve-se caracterizá-lo da maneira mais simples possivel, por meio dos parâmetros fornecidos pelo inventário qualitativo. Por isso, optou-se por verificar antes os parâmetros qualitativos mais utilizados em inventários arbóreos (3.2) elegendo quais seriam os parâmetros mínimos que poderiam expressar tal sombreamento. 
As variações entre as espécies foram indicadas por meio da proporção de cada espécie no todo, avaliada por meio do IDS (expresso no item 2.1).

As temperaturas de superficie (em graus centígrados) foram obtidas com a elaboração de dados contidos nas informações produzidas pela banda 6 do sensor Thematic Mapper (TM) (espectro emitido ou

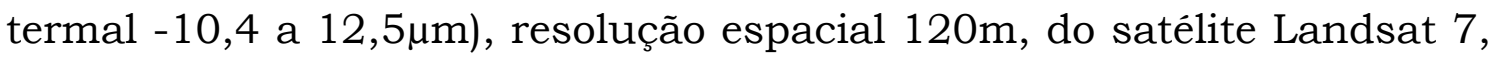
de 25 de fevereiro de 2003, identificando-se as variações térmicas intraurbanas. As imagens foram fornecidas pelo Instituto Nacional de Pesquisas Espaciais (INPE).

A transformação das informações contidas nas imagens foi feita pelo "módulo thermal" do software IDRISI 32 que converte os níveis de cinza da imagem em valores de temperatura em graus centígrados, por meio da calibração dos detectores do sensor termal do satélite Landsat 5 que serve para o satélite Landsat 7.

Para a imagem termal, a localização geográfica da área de estudo foi feita previamente.

Os dados de satélite foram comparados aos dados de temperatura do ar, medidos no posto meteorológico do Departamento de Ciências Exatas da ESALQ/USP (22 43' 30" S e 47 38' 38" O), próximo à área de estudo. As temperaturas de superficie não foram utilizadas diretamente, uma vez ser necessário a comparação das temperaturas de superficie com as do ar, para que se avaliasse quanto o tipo de cobertura do solo estava influenciando no índice de qualidade. Desta forma, a temperatura de superficie foi considerada como um fator que, se alto, diminuiria a qualidade do IQEVUe.

A hidrologia foi avaliada a partir das condições de permeabilidade do solo. Cada tipo de cobertura do solo representou um tipo de permeabilidade. 
Os tipos de cobertura do solo da área total de estudo, definidos pelo geoprocessamento, foram agrupados conforme a semelhança de grau de permeabilidade para a água de chuva, do maior para o menor, da seguinte forma:

a) Cobertura arbórea;

b) Mato;

c) Solo exposto;

d) Ambiente construído.

$\mathrm{Na}$ determinação de um parâmetro para composição de um índice de uso seguro, que mostre o tipo de desempenho hidrológico de espaços verdes em áreas urbanas, é necessário que se relativize o valor de permeabilidade de cada área em relação ao todo. Sendo assim, utilizou-se a porcentual do tipo de cobertura do solo, obtida por meio do geoprocessamento.

A fixação de Carbono foi avaliada inspirando-se na fórmula de Whitford (2001), considerando-se que o porcentual de cobertura arbórea seria o suficiente para representar essa fixação, em vez de calcular, de fato, a quantidade de Carbono por área, porque essa porcentual contém, implicitamente, a comparação entre áreas, eliminando aquelas que não têm representatividade no estoque de Carbono.

A composição do modelo de qualificação do verde, aqui apresentado, leva em consideração, portanto, duas coisas: parâmetros meteorológicos e físicos e as quantidades relativas de espaços verdes e de locais construídos. 


\subsubsection{Obtenção do Índice de Qualidade do Espaço Verde Urbano com Função Ecológica (IQEVUe)}

Ao se definir uma metodologia para obtenção do IQEVUe, considerou-se os seguintes pré-requisitos:

a) o indice deve representar, de forma abrangente, as características de qualidade dos espaços verdes urbanos;

b) o número de parâmetros a serem avaliados deve ser o menor possivel, mas eles precisam ser escolhidos de forma a representar todas as características relevantes dos espaços verdes, do ponto de vista de suas funções ecológicas;

c) o indice deve conter a contribuição direta da arborização de calçadas;

d) os parâmetros temperatura, hidrologia, fixação de Carbono devem ser considerados para todos os espaços verdes;

e) o índice deve ser um número puro, sem qualquer unidade de medida, uma vez que expressa uma "qualidade", para depois ser calculado por população que habita a área em estudo.

\subsubsection{Cálculo do IQEVUe}

A partir da definição da fórmula do IQEVUe, foram calculadas várias formas de utilizá-la para possíveis variações dos itens que compõem o índice.

O levantamento por meio das amostragens aleatória e estratificada, para a arborização de calçadas, foram comparadas ao censo para diagnosticar se tais métodos representaram bem a 
realidade e determinar qual melhor método de obtenção de dados para aplicação do IQEVUe.

O índice foi calculado para o ano de 2003.

\subsubsection{Aplicação do IQEVUe}

A aplicação do IQEVUe foi realizada testando-se os parâmetros utilizados para o índice, de forma a extrapolar os dados, utilizando as indicações de situações ideais relatadas na literatura, assim como as possibilidades reais da área em estudo, levantadas nesse trabalho.

O sombreamento de calçadas foi testado utilizando-se as coletas de dados para o levantamento da arborização de calçadas.

Os parâmetros hidrologia e fixação de Carbono foram testados a partir de levantamento feito pelo geoprocessamento que melhor resultado apresentou, em função de obter as proporções do tipo de cobertura do solo.

A variável temperatura não pôde ser extrapolada, porque a imagem de satélite somente foi obtida para o verão de 2003, mas testouse a temperatura média diária e a temperatura do horário de passagem do satélite.

As propostas de aplicação do índice e de como inseri-lo no planejamento urbano foram estabelecidas a partir de comparações do IQEVUe com o Índice de Espaços Livres de Uso Público (IELUP), com a Porcentagem de Espaço Livre de Uso Público (PELUP), com o Índice de Cobertura Vegetal em Áreas Urbanas (ICVAU) e com o Índice de Verde por Habitante (IVH). Tais comparações tiveram como intuito mostrar que o indice pode acrescentar informações aos indices quantitativos existentes. 


\section{RESULTADOS E DISCUSSÃO}

A apresentação dos resultados foi dividida em 5 etapas, com a finalidade didática de construção do pensamento, para que se compreenda a proposta de elaboração de um índice de qualidade ecológica do espaço verde.

\subsection{Arborização viária}

\subsubsection{Comparação entre censo, amostragem aleatória simples e amostragem estratificada na arborização viária de calçadas}

\subsubsection{Comparação em função do número de árvores e arbustos}

Constatou-se que os dados das amostragens não estavam muito díspares em relação ao censo (Tabela 3), quando se comparou arv/ $\mathrm{km}$ e número de árvores total nos quarteirões definidos e medidos pela planta baixa do Município. Porém, os quarteirões apresentavam distorções, pois nem sempre a realidade correspondia à planta baixa. Tal fato levou à uma nova divisão dos quarteirões pelas observações em campo e pela fotografia aérea e medidas dos quarteirões feitas na planta baixa e na 
videografia. Essas medidas são mostradas na ordem em que os quarteirões foram sorteados para a amostragem (Tabela 4).

As Tabelas 5, 6, 7 e 8 contêm as comparações dos resultados do censo, da amostragem aleatória simples e da amostragem estratificada nos quarteirões definidos pela fotografia aérea, quarteirões estes medidos, ora na planta baixa, ora na videografia. As medições foram feitas em 2001 (Tabelas 5 e 6) e 2003 (Tabelas 7 e 8).

Tabela 3. Resultados do Censo, da Amostragem Aleatória Simples e da Amostragem Estratificada na arborização urbana do bairro Santa Cecília, Piracicaba - SP, em quarteirões definidos pela planta baixa e medidos na planta baixa, em 2001

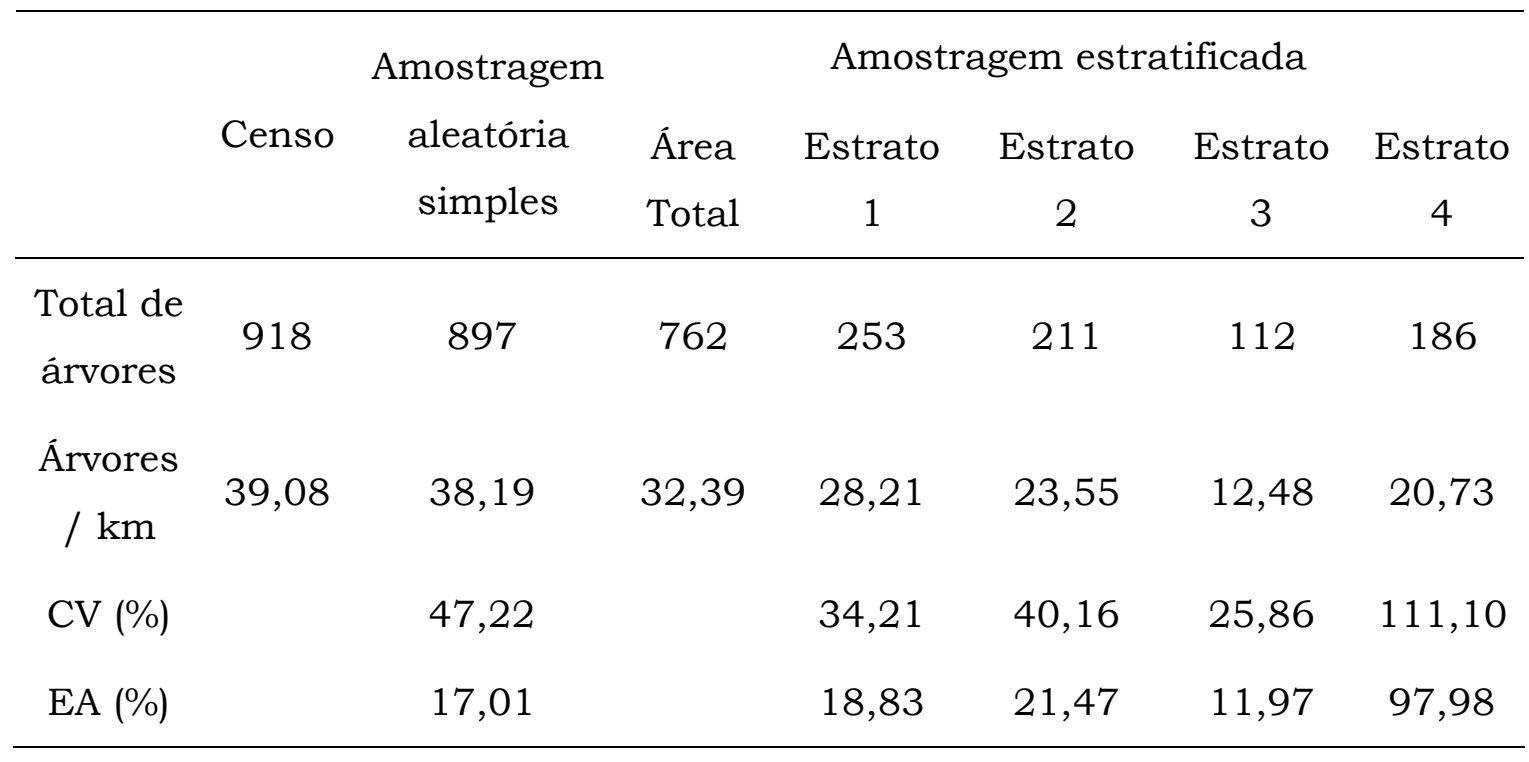


Tabela 4. Tamanho dos quarteirões definidos pela fotografia aérea, medidos na planta baixa e na videografia, presentes na arborização urbana do bairro Santa Cecília, Piracicaba - SP

\begin{tabular}{|c|c|c|}
\hline Quarteirão & Área na planta baixa & Área na videografia \\
\hline 3 & 387,48 & 380,49 \\
\hline 48 & 785,74 & 765,68 \\
\hline 2 & 425,09 & 407,60 \\
\hline 16 & 450,48 & 402,88 \\
\hline 19 & 935,71 & 889,80 \\
\hline 23 & 411,49 & 378,22 \\
\hline 57 & 418,50 & 382,73 \\
\hline 41 & 398,19 & 373,20 \\
\hline 54 & 221,57 & 211,16 \\
\hline 8 & 246,84 & 214,84 \\
\hline 11 & 214,20 & 214,02 \\
\hline 7 & 885,92 & 845,67 \\
\hline 1 & 376,18 & 383,68 \\
\hline 4 & 408,22 & 385,51 \\
\hline 6 & 471,20 & 467,66 \\
\hline 9 & 130,05 & 163,43 \\
\hline 10 & 403,26 & 353,29 \\
\hline 12 & 226,97 & 220,33 \\
\hline 13 & 403,16 & 393,82 \\
\hline 14 & 209,58 & 197,14 \\
\hline 15 & 256,74 & 254,98 \\
\hline 17 & 432,27 & 412,26 \\
\hline 5 & 899,14 & 926,61 \\
\hline 18 & 557,39 & 597,55 \\
\hline 20 & 408,45 & 421,88 \\
\hline 21 & 790,72 & 776,01 \\
\hline 24 & 377,83 & 380,56 \\
\hline 26 & 395,10 & 375,21 \\
\hline 27 & 363,55 & 335,39 \\
\hline 29 & 808,73 & 795,51 \\
\hline 32 & 395,29 & 444,45 \\
\hline 33 & 411,82 & 404,53 \\
\hline
\end{tabular}


Tabela 4(cont.). Tamanho dos quarteirões definidos pela fotografia aérea, medidos na planta baixa e na videografia, presentes na arborização urbana do bairro Santa Cecília, Piracicaba - SP

\begin{tabular}{|c|c|c|}
\hline Quarteirão & Área na planta baixa & Área na videografia \\
\hline 34 & 413,32 & 385,87 \\
\hline 22 & 436,66 & 402,88 \\
\hline 35 & 412,05 & 384,50 \\
\hline 36 & 678,9 & 640,31 \\
\hline 37 & 407,87 & 383,20 \\
\hline 38 & 1206,38 & 1167,82 \\
\hline 40 & 512,00 & 501,25 \\
\hline 42 & 404,68 & 373,84 \\
\hline 43 & 978,87 & 959,02 \\
\hline 44 & 236,64 & 249,10 \\
\hline 45 & 251,15 & 239,83 \\
\hline 46 & 166,129 & 167,13 \\
\hline 30 & 170,69 & 206,51 \\
\hline 47 & 163,47 & 188,89 \\
\hline 49 & 161,26 & 171,39 \\
\hline 50 & 205,48 & 153,16 \\
\hline 51 & 127,48 & 125,59 \\
\hline 52 & 220,85 & 259,02 \\
\hline 53 & 235,35 & 189,54 \\
\hline 55 & 237,85 & 248,70 \\
\hline 56 & 154,10 & 109,31 \\
\hline 31 & 761,67 & 711,85 \\
\hline 28 & 758,70 & 695,15 \\
\hline 25 & 622,44 & 601,32 \\
\hline 39 & 1005,17 & 1049,95 \\
\hline Total & 25435,55 & 24721,22 \\
\hline
\end{tabular}


Tabela 5. Resultados do Censo, da Amostragem Aleatória Simples e da Amostragem Estratificada na arborização urbana do bairro Santa Cecília, Piracicaba - SP, em quarteirões definidos pela fotografia aérea e medidos na planta baixa, em 2001

\begin{tabular}{|c|c|c|c|c|c|c|c|}
\hline & \multirow{3}{*}{ Censo } & \multirow{3}{*}{$\begin{array}{c}\text { Amostragem } \\
\text { aleatória } \\
\text { simples }\end{array}$} & \multicolumn{5}{|c|}{ Amostragem estratificada } \\
\hline & & & Área & Estrato & Estrato & Estrato & Estrato \\
\hline & & & Total & 1 & 2 & 3 & 4 \\
\hline $\begin{array}{l}\text { Total de } \\
\text { árvores }\end{array}$ & 958 & 900 & 779 & 297 & 217 & 141 & 124 \\
\hline $\begin{array}{c}\text { Árvores } \\
\text { / km }\end{array}$ & 37,66 & 35,38 & 30,64 & 36,22 & 26,48 & 17,18 & 15,16 \\
\hline CV (\%) & & 46,77 & & 32,30 & 51,11 & 37,20 & 70,52 \\
\hline EA (\%) & & 17,32 & & 19,35 & 29,51 & 38,98 & 60,39 \\
\hline
\end{tabular}

Tabela 6. Resultados do Censo, da Amostragem Aleatória Simples e da Amostragem Estratificada na arborização urbana do bairro Santa Cecília, Piracicaba - SP, em quarteirões definidos pela fotografia aérea e medidos na videografia, em 2001

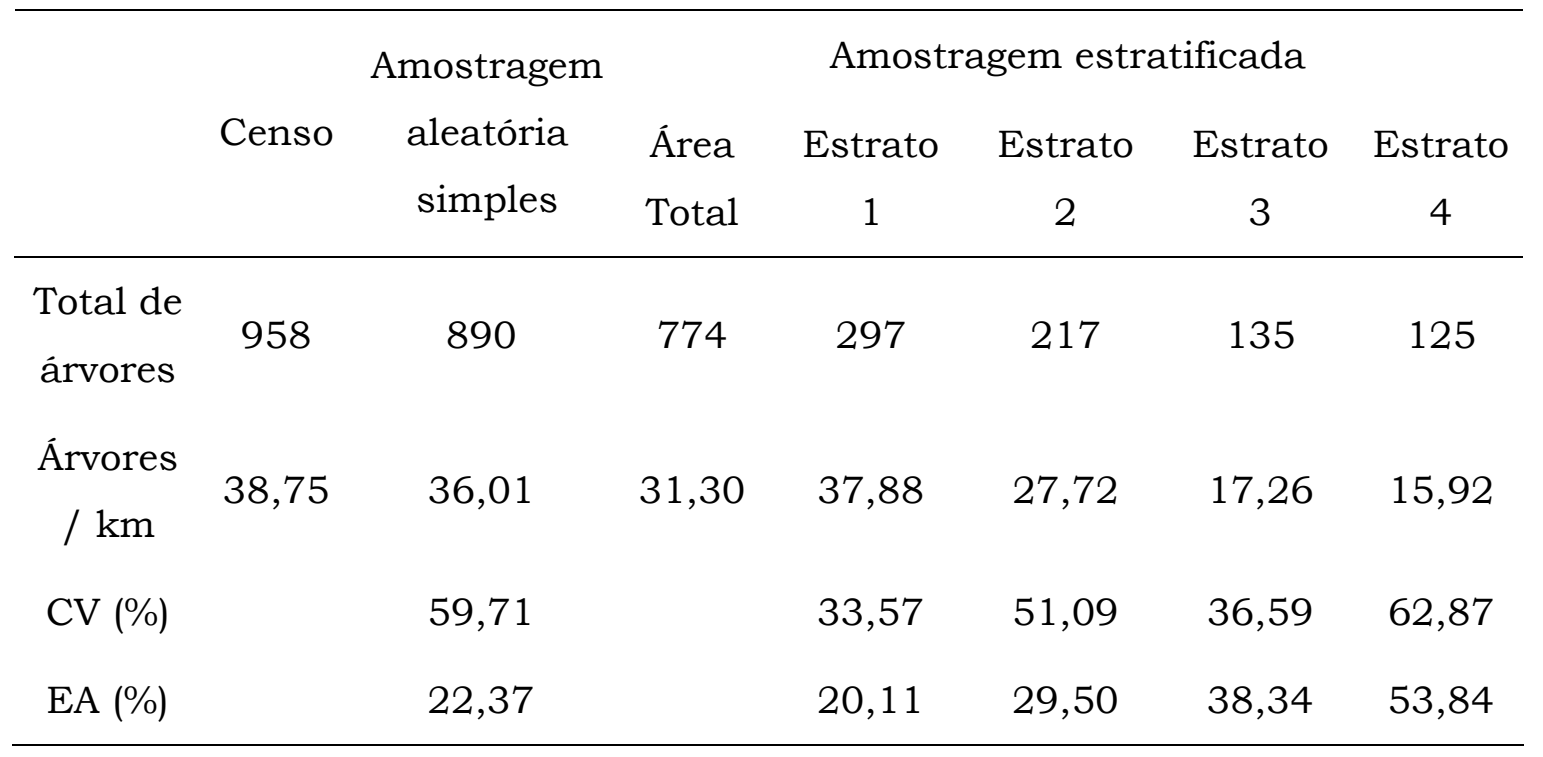


Tabela 7. Resultados do Censo, da Amostragem Aleatória Simples e da Amostragem Estratificada na arborização urbana do bairro Santa Cecília, Piracicaba - SP, em quarteirões definidos pela fotografia aérea e medidos na planta baixa, em 2003

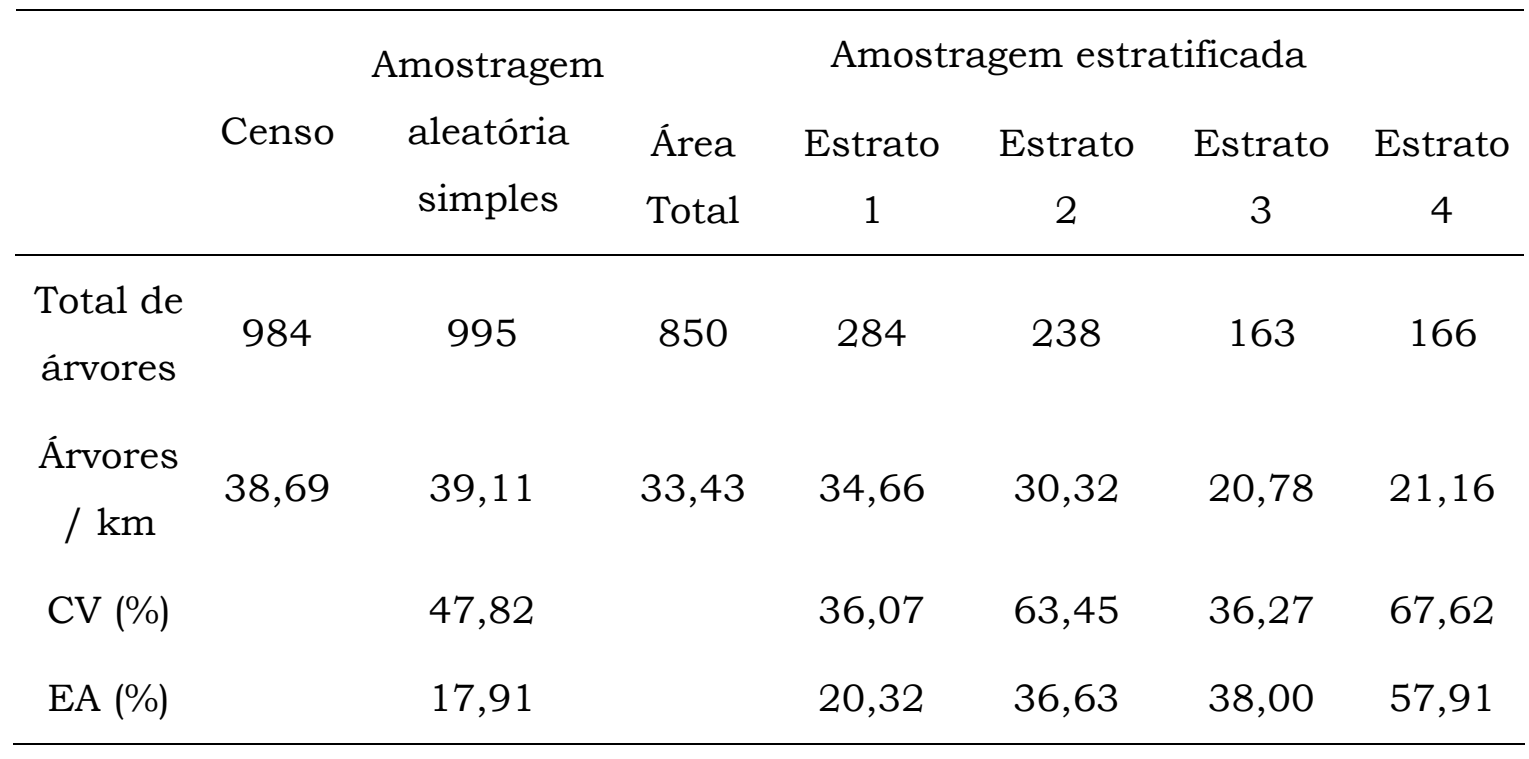

Tabela 8. Resultados do Censo, da Amostragem Aleatória Simples e da Amostragem Estratificada na arborização urbana do bairro Santa Cecília, Piracicaba - SP, em quarteirões definidos pela fotografia aérea e medidos na videografia, em 2003

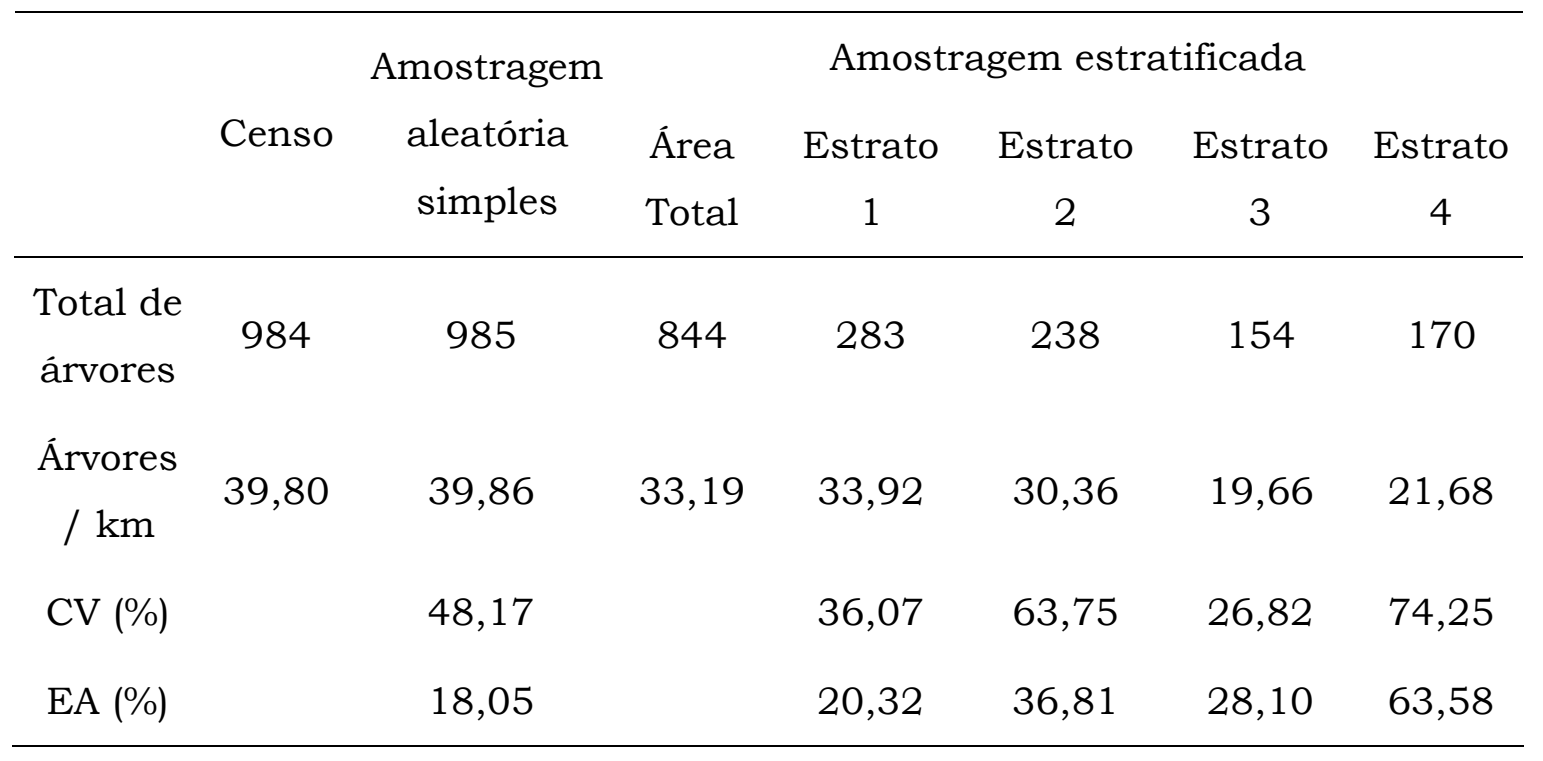


Observou-se que o número total de árvores e o número de árvores por quilômetro de calçada encontrados na amostragem aleatória simples são semelhantes aos números reais levantados no censo, em todos os casos. Os valores totais de árvores que mais se aproximaram do censo foram os da amostragem aleatória simples dos quarteirões medidos na videografia, no levantamento de 2003, com uma diferença de apenas $0,1 \%$ a mais (Tabela 8 ); os que mais se afastaram do censo foram os do levantamento de 2001, da amostragem aleatória simples dos quarteirões medidos na videografia, diminuindo em $7,1 \%$ (Tabela 6).

Os valores da amostragem estratificada, considerando a média de todos os estratos, obtida a partir do total de árvores dos estratos, apresentaram uma maior discrepância em relação aos resultados do censo. A menor diferença de estimativa foi de $13,6 \%$ para o levantamento em 2003 e medições na planta baixa (Tabela 7). A maior diferença foi de 19,2\% a menos que o censo no ano de 2001, com a medição da videografia (Tabela 6). Cabe lembrar que o número total de árvores dos estratos não foi obtido simplesmente pela soma dos valores individuais de cada estrato e, sim, pela média dos estratos (já ponderada) multiplicada pelo número de estratos.

Quando se faz comparações semelhantes, em relação ao número de árvores por quilômetro de calçada, as diferenças entre amostragens e censo permanecem proporcionalmente as mesmas, com exceção de um caso de amostragem estratificada (Tabela 8) que, comparando-se o total da amostragem ao censo, exibe maior diferença porcentual $(16 \%$ a menos) que o número total de árvores (14\% a menos).

A avaliação dos números de árvores deve ser acompanhada da análise do erro amostral (EA). Na amostragem aleatória simples, o erro amostral é de $17 \%$ - 18\%, em média, exceção feita ao valor da Tabela 7 , que é de $22,37 \%$. Essa análise é importante para se ter uma idéia do 
quanto esse tipo de amostragem é válida para ser usada no inventário da arborização urbana.

A análise estrato a estrato mostra uma diferença de erro amostral entre eles, o que representa não haver sempre homogeneidade dentro do estrato. Por exemplo, quando, inicialmente, os quarteirões foram definidos com base na planta fornecida pela Prefeitura de Piracicaba, o estrato 3 foi o mais homogêneo e seu erro amostral foi o menor (11,97\%), enquanto que o estrato 4 se mostrou o menos homogêneo, com EA de 97,98\% (Tabela 3). Já na segunda definição dos quarteirões, baseada na foto aérea e na comprovação em campo, o estrato 1 é que passou a apresentar menor erro amostral, em todos os casos (Tabelas 5 a 8), ainda assim, sempre maior que na amostragem aleatória simples. Comparando-se os outros estratos, embora se verifique que o erro amostral aumentou um pouco, não houve tanta disparidade entre o estrato 4 e os demais, como na primeira divisão de quarteirões. Este fato demonstra que o erro amostral está evidenciando que a divisão dos quarteirões feita pelas observações em campo e pela fotografia aérea foram melhores.

Quando se trata da comparação entre a média geral dos estratos e o censo, o resultado mostrado na Tabela 6 é o que mais se aproxima do real. O valor total de árvores por quilômetro de calçada ( $\operatorname{arv} / \mathrm{km})$ representa o número total de árvores dos 57 quarteirões dividido pela área total deles.

A amostragem aleatória simples apresentou altos coeficientes de variação, que variaram de 46,77\% (Tabela 5) a 59,71\% (Tabela 6), demonstrando uma certa imprecisão quanto à escolha das amostras. Essa variabilidade é decorrente da variação das amostras entre si. Porém, quando se avalia o todo dessa amostragem, comparado ao censo, 
ela é válida, uma vez que o coeficiente de variação, em populações, representa a validade da amostragem.

No caso da amostragem feita em 2003, a partir dos quarteirões medidos na videografia (Tabela 8), é surpreendente que seja de apenas $0,1 \%$ a diferença entre a amostragem aleatória simples e o censo, embora o coeficiente de variação seja de $48,17 \%$. Esse é o caso que Cochran (1977) chama de amostragem exata e imprecisa.

$\mathrm{Na}$ primeira definição dos quarteirões (Tabela 3), ainda em relação ao $\mathrm{CV}$, verifica-se maior precisão no estrato 3 e maior imprecisão no estrato 4. Tal fato mostra que o estrato 3 possui uma amostragem mais homogênea, o que é comprovado em campo, ao observar-se a uniformidade dos lotes e das calçadas. Embora as frentes dos lotes sejam grandes, as calçadas são estreitas, dificultando o plantio de árvores. A comprovação disso é a baixa densidade, que é 12,48 arv/km. $\mathrm{Na}$ segunda definição dos quarteirões (Tabelas $5,6,7$ e 8), há dificuldade de se avaliar a precisão das amostras, pois há diferenças entre os valores de coeficiente de variação nas duas épocas de amostragem e nos dois tipos de mensuração dos quarteirões, ora apontando para um estrato como o mais homogêneo, ora para outro.

A escolha da estratificação, baseada nos loteamentos que fazem parte do bairro, levou em consideração os fatores mais evidentes: época de implantação do loteamento e proximidade física dos quarteirões. Essa "coesiva" mostra que, no estrato 1 , há uma maior densidade de árvores que nos outros estratos, por ser um loteamento mais antigo e a arborização já ter sido fixada, de certa forma. Por outro lado, as frentes dos lotes são menores que os lados. Isso representa maior ou menor probabilidade de existirem árvores, dependendo do tamanho da entrada da garagem. 
No estrato 2, a ocupação foi mais recente que no estrato 1 , o que não impediu que o estrato 2 apresentasse uma maior densidade que o estrato 3, que é mais antigo. As informações obtidas in loco são de que os moradores iniciaram o plantio assim que as casas foram construídas, Há, ainda, muitos terrenos com construções em andamento, o que justifica um coeficiente de variação de $40 \%$ a $64 \%$.

Observando-se os dados estatísticos do estrato 4, verifica-se um alto coeficiente de variação em todos os casos e uma densidade de árvores entre os estratos que não é a mais alta, tão pouco a mais baixa, como mostram as Tabelas 3, 7 e 8. A densidade entre os estratos é mais baixa, nos casos dos dados das Tabelas 4, 5 e 6 . Isso demonstra a heterogeneidade desses estratos, mesmo quando se modificou a definição de seus quarteirões.

A dificuldade de se definir um estrato homogêneo, que mantivesse os critérios anteriormente estipulados para todos os estratos, apresentou-se mais acentuada no estrato 4, uma vez que nele estão presentes áreas não ocupadas, portanto, sem arborização. Dessa forma, observa-se que terrenos pioneiramente ocupados com construções, por serem grandes e possuírem toda sua extensão frontal com árvores, influenciaram na elevação do cômputo geral de árvores.

O levantamento foi realizado em dois anos, para obter uma idéia das modificações temporais na arborização urbana; o foco foi a arborização viária, aquela que mais sofre com os danos da ação antrópica. Os tipos de definição dos quarteirões e sua forma de mensuração serviram para avaliar as diferenças de resultados, o que é útil para quem fizer uso dessa metodologia na determinação do Índice de Qualidade do Espaço Verde Urbano com Função Ecológica. Os resultados aqui apresentados dão uma idéia das diferentes formas de se obter esse índice. Na seqüência, são feitas comparações com dados de 
outros levantamentos, obtidos por meio de amostragem aleatória simples mais recente e baseados em quarteirões definidos pela fotografia aérea e medidos pela videografia (Tabela 8), visando melhor retratar a realidade atual.

Os valores encontrados podem ser comparados a levantamentos recentes, como os de Rachid e Couto (1999) e de Meneghetti (2003), respectivamente para a cidade de São Carlos e para sete bairros de Santos. O número deaárvores por quilômetro de calçada obtido por Rachid e Couto (1999), com a amostragem aleatória simples, foi de 30,12, com um erro amostral de 9,6\%, enquanto que Meneghetti (2003) encontrou, por meio da amostragem sistemática simples, um número de $38,93 \mathrm{arv} / \mathrm{km}$ de calçada e um erro amostral de 13,08\%. Lembrando que o valor obtido no presente trabalho foi de 39,86, com um erro amostral de $17,46 \%$ (Tabela 7 ), pode-se salientar que os dados estão coerentes com os trabalhos citados.

A extrapolação dos dados permite que se obtenha um valor que corresponde ao número de árvores a cada tantos metros, como geralmente é relatado em inventários quantitativos. Portanto, verificouse que, neste trabalho, (Tabela 8) foi estimado que, em média, há uma árvore a cada 25 m, enquanto que Rachid e Couto (1999) estimaram que havia uma árvore a cada $37 \mathrm{~m}$, certo para a média da cidade de São Carlos toda, e Meneghetti (2003) estimou uma árvore a cada 26m, para os sete bairros de Santos.

A avaliação desses números pode ser feita com base no trabalho de Milano (1990), que considera uma árvore a cada $12 \mathrm{~m}$ como um índice adequado, em uma boa arborização. Contudo, há de se levar em consideração, entre outros fatores, a existência, a dimensão e a qualidade da copa da árvore, ou seja, a cobertura arbórea do local, o que demonstra a superficialidade da discussão baseada em árvores por 
quilômetro. Cabe ressaltar que, em muitos casos, quando se fala em árvores por quilômetro de calçada, não se diferenciam árvores de arbustos, ou se a vegetação está cumprindo as funções esperadas.

Analisou-se também o potencial de plantio de árvores em relação ao espaço nas calçadas, no ano de 2001, obtendo-se um número de 353 árvores a serem plantadas. Esse número baseou-se nas distâncias mínimas exigidas, tais como esquinas, entradas de veículos e equipamentos comunitários. Poucas mudanças ocorreram em um intervalo de 2 anos. O aumento no plantio de árvores foi pouco expressivo. Quando se avalia por meio da amostragem, há um incremento de 95 árvores, equivalente a 10\%. Porém, dados do censo indicam que, na realidade, houve um aumento de 958 para 984, equivalente a $3 \%$.

Quando se considera o total de árvores que já estão plantadas nas parcelas, mais o total de árvores que poderiam ser plantadas, o número de arv/ $\mathrm{km}$ atingiria 82,42, ou seja, uma árvore a cada 12,13m. Para o bairro todo, a extrapolação dos dados indicaria que o valor total seria de, aproximadamente, 2037 árvores, com um CV de 40,12\% e um EA de 15,03\%. Dessa forma, o dimensionamento atual da arborização do bairro está muito aquém de seu potencial.

A qualidade da arborização urbana é muitas vezes renegada a segundo plano, privilegiando-se a quantidade de árvores por metro linear. Os órgão gestores preferem políticas de plantio de mudas de arbustos que podem fazer volume em termos de número de plantas por metro linear, mas que não representam muito em termos de cobertura arbórea por área. Um outro aspecto é optar pela "lei do menor esforço", isto é, plantar arvoretas que não atingem a fiação secundária e não destroem calçadas, em vez de enfrentar os problemas da arborização. Por outro lado, as arvoretas têm superbrotamento do ramo principal, o 
que atrapalha transeuntes e veículos, além delas não cumprirem funções de conforto térmico. A arborização de calçadas com espécies de porte adequado exige uma convivência com conflitos, desde a queda de folhas, até a possivel ruptura das calçadas e o contato com a fiação elétrica.

A questão a ser enfrentada é a necessidade de mudança de paradigma. Os equipamentos urbanos é que devem se adaptar a uma arborização com qualidade e não o contrário.

\subsubsection{Comparação em função das espécies de árvores e arbustos}

A comparação do tipo de amostragem suscitou fatos relevantes que podem ser analisados pelo aspecto puramente quantitativo, estatístico, bem como pelo aspecto qualitativo da arborização. Assim, a identificação das espécies utilizadas na arborização é importante para definir o índice qualitativo proposto neste trabalho.

A comparação entre espécies levantadas no censo e nas amostragens será apresentada apenas para os quarteirões definidos pela fotografia aérea. Nas Tabela 9 e 10 estão relacionadas as espécies levantadas nas amostragens comparadas às obtidas pelos censos de 2001 e 2003, respectivamente. Apenas as 15 espécies levantadas no censo estão relacionadas nas tabelas 9 e 10. 
Tabela 9. Espécies levantadas no censo e nas amostragens aleatória simples e estratificada, na arborização urbana do bairro Santa Cecília, Piracicaba - SP, em quarteirões definidos pela fotografia aérea, em 2001

\begin{tabular}{|c|c|c|c|c|c|c|}
\hline \multirow{3}{*}{ Espécies } & \multirow{3}{*}{$\begin{array}{c}\text { Censo } \\
(\%)\end{array}$} & Amostragem & \multicolumn{4}{|c|}{ Amostragem estratificada (\%) } \\
\hline & & aleatória & Estrato & Estrato & Estrato & Estrato \\
\hline & & simples (\%) & 1 & 2 & 3 & 4 \\
\hline Murraya paniculata & 15,97 & 19,75 & 36,30 & 0,94 & 12,00 & 13,16 \\
\hline $\begin{array}{l}\text { Caesalpinia } \\
\text { peltophoroides }\end{array}$ & 12,63 & 14,33 & 15,75 & 13,21 & 20,00 & 7,89 \\
\hline $\begin{array}{l}\text { Lagerstroemia } \\
\text { indica }\end{array}$ & 8,98 & 7,01 & 2,05 & 8,49 & 8,00 & 21,05 \\
\hline Tabebuia sp. & 8,98 & 8,60 & 3,42 & 10,38 & 12,00 & 21,05 \\
\hline Schinus molle & 6,68 & 2,23 & 2,05 & 3,77 & - & - \\
\hline Terminalia catappa & 4,18 & 3,82 & 4,11 & 5,66 & - & - \\
\hline Thevetia peruviana & 3,86 & 3,50 & 4,11 & 2,83 & - & 5,26 \\
\hline Licania tomentosa & 3,65 & 3,82 & 2,05 & 8,49 & - & - \\
\hline $\begin{array}{l}\text { Tibouchina } \\
\text { granulosa }\end{array}$ & 3,44 & 2,55 & 4,11 & 0,94 & - & 2,63 \\
\hline $\begin{array}{l}\text { Syagrus } \\
\text { romanzoffiana }\end{array}$ & 3,24 & 5,10 & - & 10,38 & - & - \\
\hline Nerium oleander & 3,13 & 1,91 & 1,37 & 3,77 & - & - \\
\hline $\begin{array}{l}\text { Hibiscus } \quad \text { rosa- } \\
\text { sinensis }\end{array}$ & 2,71 & 3,50 & 0,68 & 9,43 & - & - \\
\hline Delonix regia & 2,51 & - & - & - & - & 0,00 \\
\hline Ficus microcarpa & 1,88 & 4,14 & 6,85 & 1,89 & - & - \\
\hline $\begin{array}{l}\text { Enterolobium } \\
\text { contortisiliquum }\end{array}$ & 1,77 & - & - & - & - & - \\
\hline Outras & 16,39 & 19,75 & 17,12 & 19,81 & 48,00 & 26,32 \\
\hline
\end{tabular}


Tabela 10. Espécies levantadas no censo e nas amostragens aleatória simples e estratificada, na arborização urbana do bairro Santa Cecília, Piracicaba - SP, em quarteirões definidos pela fotografia aérea, em 2003

\begin{tabular}{|c|c|c|c|c|c|c|}
\hline \multirow{3}{*}{ Espécies } & \multirow{3}{*}{$\begin{array}{c}\text { Censo } \\
(\%)\end{array}$} & \multirow{3}{*}{$\begin{array}{c}\text { Amostragem } \\
\text { aleatória } \\
\text { simples (\%) }\end{array}$} & \multicolumn{4}{|c|}{ Amostragem estratificada (\%) } \\
\hline & & & Estrato & Estrato & Estrato & Estrato \\
\hline & & & 1 & 2 & 3 & 4 \\
\hline Murraya paniculata & 19,11 & 17,86 & 36,69 & 0,84 & 7,41 & 12,00 \\
\hline $\begin{array}{l}\text { Caesalpinia } \\
\text { peltophoroides }\end{array}$ & 11,48 & 11,90 & 16,55 & 10,92 & 14,81 & - \\
\hline $\begin{array}{l}\text { Lagerstroemia } \\
\text { indica }\end{array}$ & 8,74 & 6,85 & 2,16 & 2,52 & 7,41 & 16,00 \\
\hline Tabebuia sp. & 8,03 & 8,63 & 2,88 & 10,08 & 11,11 & 20,00 \\
\hline Schinus molle & 7,72 & 4,17 & 2,16 & 5,04 & 11,11 & 4,00 \\
\hline Nerium oleander & 4,47 & 2,98 & 2,16 & 3,36 & - & - \\
\hline Licania tomentosa & 4,47 & 2,98 & 2,16 & 8,40 & - & 4,00 \\
\hline $\begin{array}{l}\text { Syagrus } \\
\text { romanzoffiana }\end{array}$ & 3,46 & 3,27 & - & 9,24 & - & 18,00 \\
\hline $\begin{array}{l}\text { Tibouchina } \\
\text { granulosa }\end{array}$ & 3,15 & 1,49 & 2,88 & 0,84 & - & 2,00 \\
\hline Terminalia catappa & 2,54 & 6,25 & 4,32 & 6,72 & - & - \\
\hline Delonix regia & 2,44 & 2,08 & - & - & - & - \\
\hline $\begin{array}{l}\text { Hibiscus rosa- } \\
\text { sinensis }\end{array}$ & 2,24 & 3,57 & 0,72 & 8,40 & - & - \\
\hline Thevetia peruviana & 2,03 & - & 3,60 & 3,36 & - & - \\
\hline $\begin{array}{l}\text { Enterolobium } \\
\text { contortisiliquum }\end{array}$ & 1,63 & - & - & - & - & 4,00 \\
\hline Ficus microcarpa & 1,42 & 3,57 & 6,47 & 6,47 & - & 2,00 \\
\hline Outras & 17,07 & 24,40 & 17,27 & 23,78 & 48,15 & 18,00 \\
\hline
\end{tabular}

A análise da Tabela 9 demonstra que há poucas espécies que ocupam a maior parte da área arborizada. Pelo censo, observa-se que as 15 espécies mais plantadas compõem $84 \%$ do número de árvores, enquanto que, na amostragem aleatória simples e nos estratos 1, 2, 3 e 4, as mesmas espécies compõem $80 \%, 83 \%, 80 \%, 52 \%$ e $74 \%$, 
respectivamente. Nem todas as espécies levantadas no censo apareceram nas amostragens; as espécies Delonix regia e Enterolobium contorsiquum não se apresentavam entre as 15 mais freqüentes. A avaliação do número de espécies dos estratos mostrou que o número de espécies não presentes entre as 15 acima citadas foram: estrato 1: 3 espécies; estrato 2: 2 espécies; estrato 3: 11 espécies; estrato 4 :8 espécies. É importante ressaltar que, no estrato 3, a quantidade de espécies estaria relacionada ao histórico da área, tanto em relação ao nível econômico, quanto à qualidade da arborização.

No ano de 2003, a Tabela 10 mostra que as 15 espécies mais plantadas representaram $83 \%$ do número de árvores, enquanto que, na amostragem aleatória simples e nos estratos 1, 2, 3 e 4, as mesmas espécies compõem $80 \%, 76 \%, 83 \%$, 52\% e $82 \%$, respectivamente. Entre as 15 espécies mais plantadas, levantadas no censo, não apareciam 2 na amostragem aleatória simples, a saber: Enterolobium contortisiliquum e Thevetia peruviana. Na amostragem estratificada, os números de espécies que não apareciam em cada estrato, considerando as 15 levantadas pelo censo, foram: estrato 1: 3 espécies; estrato 2: 2 espécies; estrato 3: 10 espécies; estrato 4: 6 espécies.

As espécies Murraya paniculata (falsa-murta) e Caesalpinia peltophoroides (Tabelas 8 e 9) apresentaram-se com uma participação maior que $10 \%$ nos dois anos de levantamento. Tal fato contraria a recomendação de Grey \& Deneke (1978), de Miller \& Miller (1991) e de Santamour (2002), que é de que se plante, no máximo, 10\% de cada espécie. Barker (1975) sugere que não seja plantado mais de $5 \%$ de qualquer espécie. Santamour ainda acrescenta que, além de não ser recomendável plantar mais que 10\% de uma espécie, não se deve exceder a $20 \%$ do mesmo gênero e não mais que $30 \%$ da mesma família. Richards (1993), por outro lado, questiona esses limites numéricos fixados, sugerindo que uma espécie só será 
considerada em excesso, se outras variedades que não estão sendo plantadas forem provavelmente melhores e não estiverem sendo consideradas. Porém, o uso excessivo de uma ou outra espécie pode criar condições que acarretariam maior perda, no caso de problemas específicos daquela espécie.

Nas Tabelas 11 e 12 estão listadas todas as espécies levantadas na amostragem aleatória simples em 2001 e 2003, nos quarteirões definidos pela videografia, para que se tenha uma idéia da modificação temporal completa das espécies plantadas e do corte das existentes, bem como da freqüência de cada uma, no local amostrado. Nas Figuras 3 e 4 estão expostas as classes vegetais presentes nas calçadas.

Tabela 11. Espécies levantadas na amostragem aleatória simples na arborização urbana do bairro Santa Cecília, Piracicaba - SP, em quarteirões definidos pela videografia, em 2001

\begin{tabular}{llcc}
\hline \multicolumn{1}{c}{ Nome científico } & \multicolumn{1}{c}{ Nome vulgar } & No árvores & Freqüência\% \\
\hline Murraya paniculata & Falsa-murta & 62 & 19,75 \\
Caesalpinia peltophoroides & Sibipiruna & 45 & 14,33 \\
Tabebuia sp & Ipê & 27 & 8,60 \\
Lagerstroemia indica & Resedá & 22 & 7,01 \\
Syagrus romanzoffiana & Jerivá & 16 & 5,10 \\
Ficus microcarpa & Fícus benjamina & 13 & 4,14 \\
Terminalia catappa & Chapéu-de-Sol & 12 & 3,82 \\
Licania tomentosa & Oiti & 12 & 3,82 \\
Archontophoenix alexandrae & Seafortia & 12 & 3,82 \\
Thevetia peruviana & Chapéu-de-Napoleão & 11 & 3,50 \\
Hibiscus rosa- sinensis & Hibisco & 11 & 3,50 \\
Tibouchina granulosa & Quaresmeira & 8 & 2,55 \\
Schinus molle & Aroeira salsa & 7 & 2,23 \\
Nerium oleander & Espirradeira & 6 & 1,91 \\
Ligustrum japonicum & Ligustro & 6 & 1,91 \\
Caesalpinia pulcherrima & Flamboyant-mirim & 4 & 1,27
\end{tabular}


Tabela 11. (cont.) Espécies levantadas na amostragem aleatória simples na arborização urbana do bairro Santa Cecília, Piracicaba SP, em quarteirões definidos pela videografia, em 2001

\begin{tabular}{|c|c|c|c|}
\hline Nome científico & Nome vulgar & No árvores & Freqüência\% \\
\hline $\begin{array}{l}\text { Caesalpinia ferrea var. } \\
\text { leiostachya }\end{array}$ & Pau-ferro & 4 & 1,27 \\
\hline Cassia fistula & Chuva-de-ouro & 3 & 0,96 \\
\hline Caesalpinia echinata & Pau-Brasil & 3 & 0,96 \\
\hline Prunus salicina & Ameixeira & 2 & 0,64 \\
\hline Codiaeum variegatum & Cróton & 2 & 0,64 \\
\hline Chorisia speciosa & Paineira & 2 & 0,64 \\
\hline Pinus elliottii & Pinheiro & 2 & 0,64 \\
\hline Persea americana & Abacateiro & 1 & 0,32 \\
\hline Malpighia glabra & Acerola & 1 & 0,32 \\
\hline Anadenanthera colubrina & Angico & 1 & 0,32 \\
\hline Nectandra megapotamica & Canelinha & 1 & 0,32 \\
\hline Cassia grandis & Cássia grande & 1 & 0,32 \\
\hline Salix babylonica & Chorão & 1 & 0,32 \\
\hline Callistemum viminalis & Escova de Garrafa & 1 & 0,32 \\
\hline Spathodea nilotica & Espatódea & 1 & 0,32 \\
\hline Euphorbia sp. & Euforbiácea & 1 & 0,32 \\
\hline Grevilha banksii var forsteri & Grevilha-anã & 1 & 0,32 \\
\hline Plumeria rubra & Jasmim-manga & 1 & 0,32 \\
\hline Citrus lemon & Limoeiro & 1 & 0,32 \\
\hline Lafoensia glyptocarpa & Mirindiba & 1 & 0,32 \\
\hline Eugenia uniflora & Pitangueira & 1 & 0,32 \\
\hline Melia azedarach & Santa-bárbara & 1 & 0,32 \\
\hline Tipuana tipu & Tipuana & 1 & 0,32 \\
\hline Total & & 314 & \\
\hline
\end{tabular}




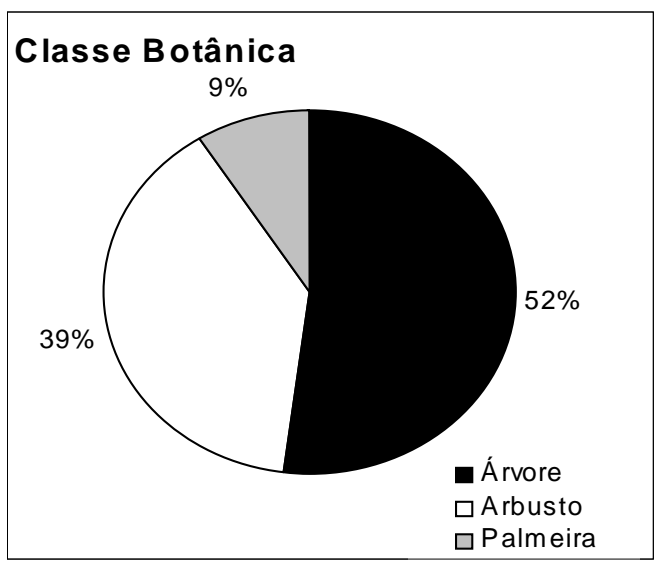

Figura 3 - Porcentual de árvores, arbustos e palmeiras na arborização urbana do bairro Santa Cecília, Piracicaba - SP, em 2001

Tabela 12. Espécies levantadas na amostragem aleatória simples, na arborização urbana do bairro Santa Cecília, Piracicaba - SP, em quarteirões definidos pela videografia, em 2003

\begin{tabular}{llcc}
\hline \multicolumn{1}{c}{ Nome cientifico } & \multicolumn{1}{c}{ Nome vulgar } & No árvores & Freqüência\% \\
\hline Murraya paniculata & Falsa-murta & 60 & 17,86 \\
Caesalpinia peltophoroides & Sibipiruna & 40 & 11,90 \\
Tabebuia sp & Ipê & 29 & 8,63 \\
Lagerstroemia indica & Resedá & 23 & 6,85 \\
Syagrus romanzoffiana & Jerivá & 21 & 6,25 \\
Schinus molle & Aroeira salsa & 14 & 4,17 \\
Ficus benjamina & Ficus & 12 & 3,57 \\
Hibiscus rosa- sinensis & Hibisco & 12 & 3,57 \\
Licania tomentosa & Oiti & 11 & 3,27 \\
Terminalia catappa & Chapéu-de-Sol & 10 & 2,98 \\
Thevetia peruviana & Chapéu-de-Napoleão & 10 & 2,98 \\
Archontophoenix alexandrae & Seafortia & 10 & 2,98 \\
Cariota uriens & Cariota & 8 & 2,38 \\
Bauhinia variegata & Pata-de-vaca & 8 & 2,38 \\
Nerium oleander & Espirradeira & 7 & 2,08
\end{tabular}


Tabela 12 (cont.). Espécies levantadas na amostragem aleatória simples, na arborização urbana do bairro Santa Cecília, Piracicaba SP, em quarteirões definidos pela fotografia aérea, em 2003

\begin{tabular}{|c|c|c|c|}
\hline Nome científico & Nome vulgar & No árvores & Freqüência\% \\
\hline Ligustrum japonicum & Ligustro & 5 & 1,49 \\
\hline Tibouchina granulosa & Quaresmeira & 5 & 1,49 \\
\hline Cocus nucifera & Coqueiro-da-baia & 4 & 1,19 \\
\hline Caesalpinia pulcherrima & Flamboyant-mirim & 4 & 1,19 \\
\hline Grevillea banksii var forsteri & Grevilha-anã & 4 & 1,19 \\
\hline $\begin{array}{l}\text { Caesalpinia ferrea var. } \\
\text { leiostachya }\end{array}$ & Pau-ferro & 4 & 1,19 \\
\hline Melalaleuca linariifolia & Melaleuca folha-fina & 3 & 0,89 \\
\hline Lafoensia glyptocarpa & Mirindiba & 3 & 0,89 \\
\hline Caesalpinia echinata & Pau-Brasil & 3 & 0,89 \\
\hline Pinus elliottii & Pinheiro & 3 & 0,89 \\
\hline Eiobotrya japonica & Nespeira & 2 & 0,60 \\
\hline Nectandra megapotamica & Canelinha & 2 & 0,60 \\
\hline Cassia grandis & Cássia grande & 2 & 0,60 \\
\hline Callistemum viminalis & Escova de Garrafa & 2 & 0,60 \\
\hline Chorisia speciosa & Paineira & 2 & 0,60 \\
\hline Persea americana & Abacateiro & 1 & 0,30 \\
\hline Acácia podalyraefolia & Acácia mimosa & 1 & 0,30 \\
\hline Malpighia glabra & Acerola & 1 & 0,30 \\
\hline Anadenanthera colubrina & Angico & 1 & 0,30 \\
\hline Muntingia calabura & Calabura & 1 & 0,30 \\
\hline Salix babylonica & Chorão & 1 & 0,30 \\
\hline Euphorbia sp & Euforbiaceae & 1 & 0,30 \\
\hline Psidium guajava & Goiabeira & 1 & 0,30 \\
\hline Plumeria rubra & Jasmim-manga & 1 & 0,30 \\
\hline Citrus lemon & Limoeiro & 1 & 0,30 \\
\hline Eugenia uniflora & Pitangueira & 1 & 0,30 \\
\hline Melia azedarach & Santa-bárbara & 1 & 0,30 \\
\hline Tipuana tipu & Tipuana & 1 & 0,30 \\
\hline Total & & 336 & \\
\hline
\end{tabular}




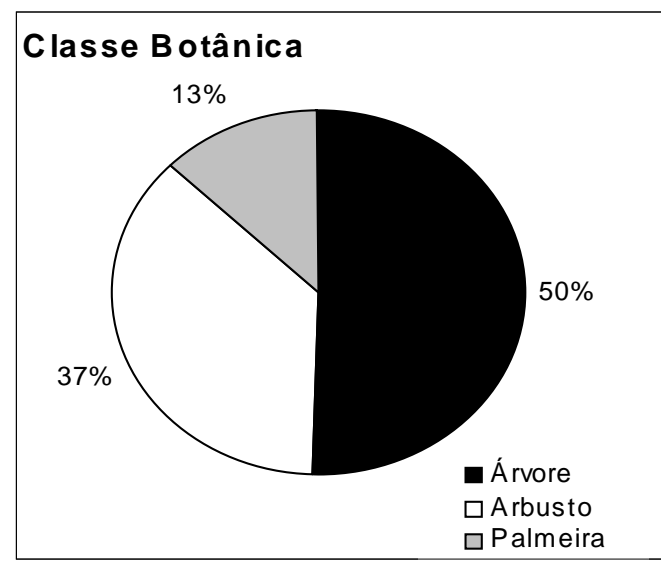

Figura 4 - Porcentual de árvores, arbustos e palmeiras na arborização urbana do bairro Santa Cecília, Piracicaba - SP, em 2003

No ano de 2001, foram levantadas um total de 40 espécies, enquanto que, em 2003, foram encontradas 43 espécies. O total de árvores, nos quarteirões amostrados, aumentou de 314 para 336. A estimativa do número total de árvores é de 890 para 2001 e 985 para 2003 (Tabelas 6 e 8).

Conforme a Figura 3, o porcentual de arbustos foi de $9 \%$ e a de árvores foi de 52\% do total em 2001, enquanto que em 2003 (Figura 4), aumentou o porcentual de palmeiras, de $9 \%$ para $12 \%$, em detrimento do porcentual de arbustos e árvores.

Este porcentual para o bairro todo mostra que aumentou o número de palmeiras, mas este percentual tem grande influência de terrenos grandes de classe média alta de um dos loteamentos do bairro. De forma geral, o maior plantio é de arbustos e a eliminação é de algumas árvores de porte alto. É a chamada "política de arbustização".

As espécies arbustivas que estão sendo atualmente plantadas no bairro (que ainda podem ser consideradas mudas) são: hibisco, resedá, chapéu-de-napoleão, espirradeira e falsa-murta; as espécies de palmeira são: jerivá, seafortia e cariota 
Os Índices de Diversidade de Shannon referentes aos anos de 2001 e 2003 são demonstrados nas Figuras 5 e 6, respectivamente.

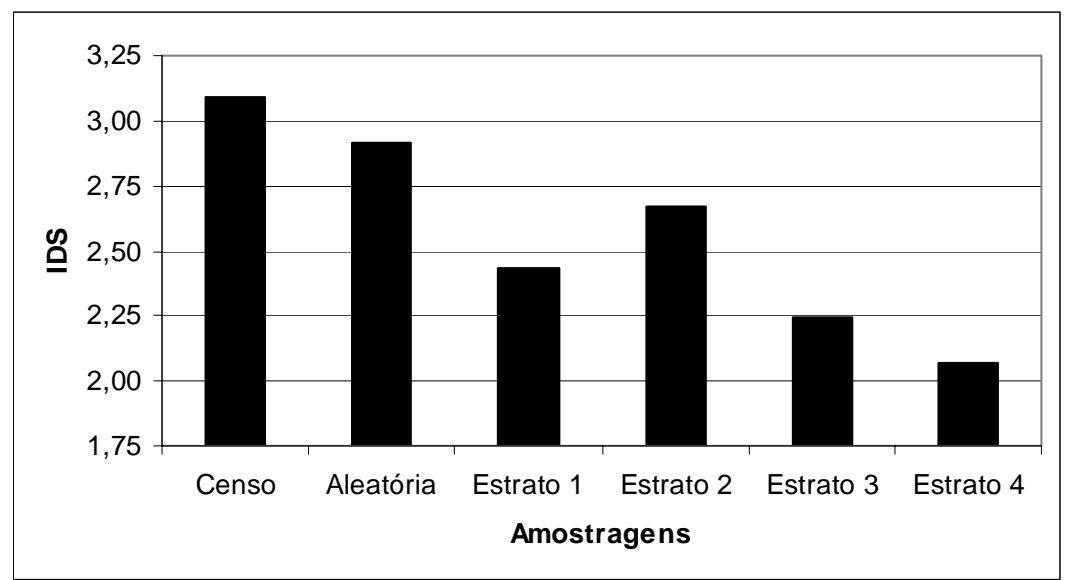

Figura 5 - Índice de Diversidade de Shannon da arborização urbana avaliado no censo, nas amostragens aleatória simples e estratificada (estratos 1 a 4) do bairro Santa Cecília, Piracicaba - SP, em 2001

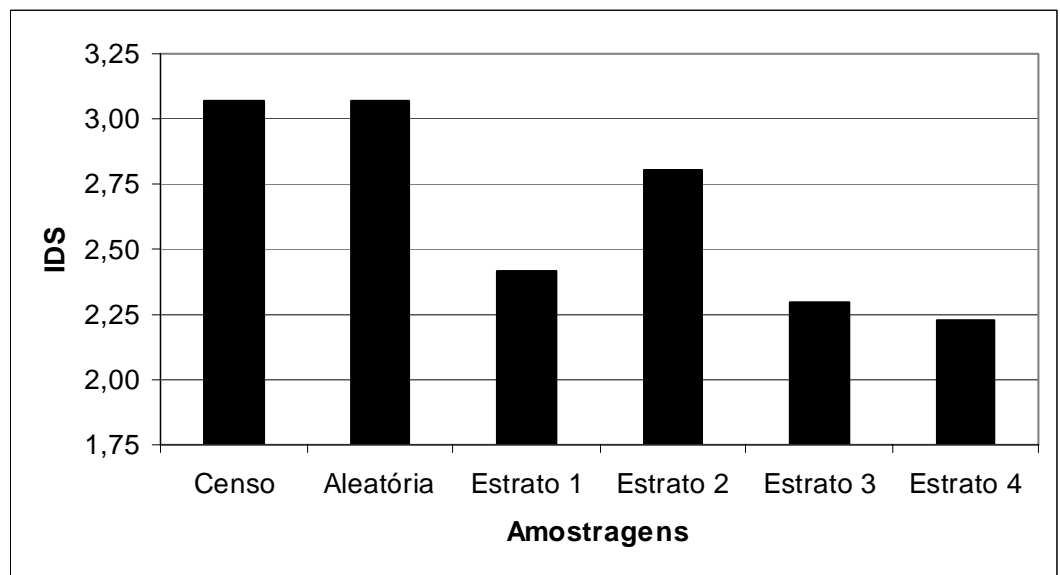

Figura 6 - Índice de Diversidade de Shannon da arborização urbana avaliados no censo, nas amostragens aleatória simples e estratificada (estratos 1 a 4) do bairro Santa Cecília, Piracicaba - SP, em 2003 
O IDS foi maior no censo que nas amostragens aleatória e estratificada, no ano de 2001 (Figura 5), e exatamente igual no censo e na amostragem e maior no censo que na amostragem estratificada no ano de 2003 (Figura 6). Para o censo, em 2001, e para o censo e amostragem aleatória simples, em 2003, os dados apresentaram uma variabilidade, interessante do ponto de vista ecológico. Por outro lado, as amostragens aleatória e estratificada, em 2001, e estratificada, em 2003, apresentaram IDS menor que 3. Segundo Martins \& Santos (2001), o IDS requer uma amostragem que englobe todas as espécies, mas essa situação ideal é quase impossivel, uma vez que há uma heterogeneidade na arborização urbana. Essa heterogeneidade pode ser uma explicação para as diferenças entre as amostragens e o censo.

Meneghetti (2003) obteve um IDS de 2,63 para 65 espécies dos estratos dos bairros da orla marítima de Santos. No presente trabalho, para o ano de 2003, o IDS variou de 2,23 a 3,07, conforme o tipo de levantamento, para 43 espécies, nas amostragens aleatória simples e estratificada e, para 63 espécies, no censo.

O IDS acrescenta informação, contribuindo para que se tenha uma idéia de como podem variar os parâmetros avaliados, uma vez que ele dá a noção de diversidade. 


\subsection{Inventário quali-quantitativo do verde viário}

\subsubsection{Espaço verde das calçadas}

\subsubsection{Arborização nas calçadas}

Os resultados dos parâmetros avaliados no inventário qualitativo das árvores de calçada, em 2001, estão expostos nas Figuras 7, 8, 9 e 10, excluindose a altura e o diâmetro. Estes estão expostos juntos aos dados de altura e diâmetro das plantas em 2003 (Figuras 11), para efeito de comparação.

Vigor
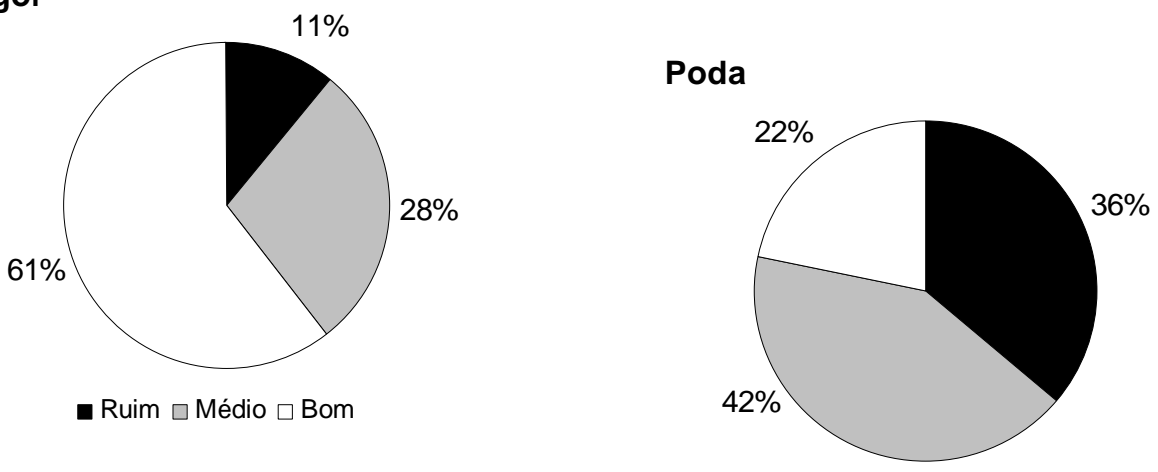

— Sem $\square$ Adequada $\square$ Inadequada
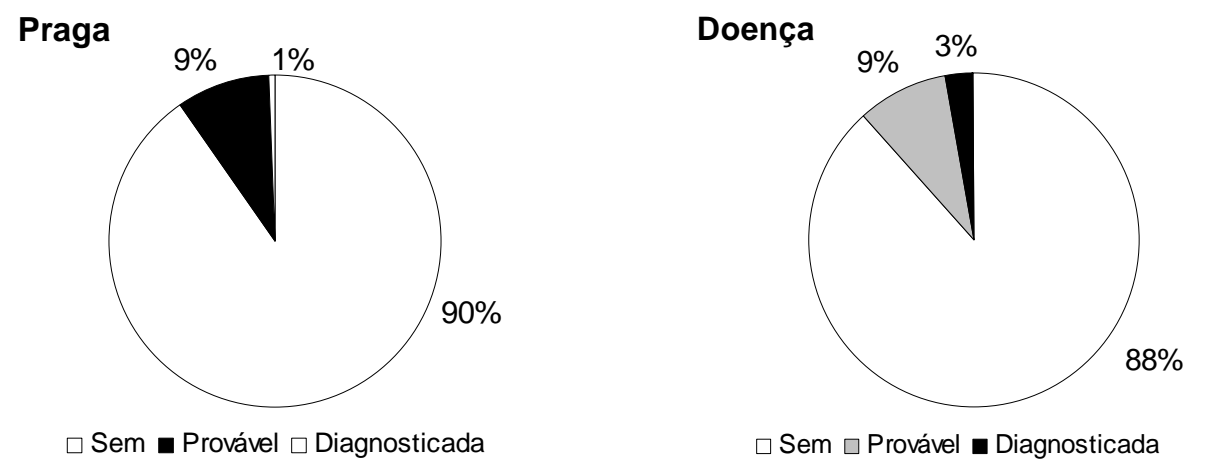

Figura 7 - Aspectos gerais (vigor e poda) e estado fitossanitário (praga ou doença) das árvores de calçada do bairro Santa Cecília, Piracicaba - SP, em 2001 
As árvores analisadas apresentaram $61 \%$ das plantas com um bom vigor aparente, enquanto que aquelas que apresentaram um vigor médio estavam relacionadas com podas inadequadas e as de vigor ruim estavam relacionadas com a presença de pragas ou doenças (Figura 7).
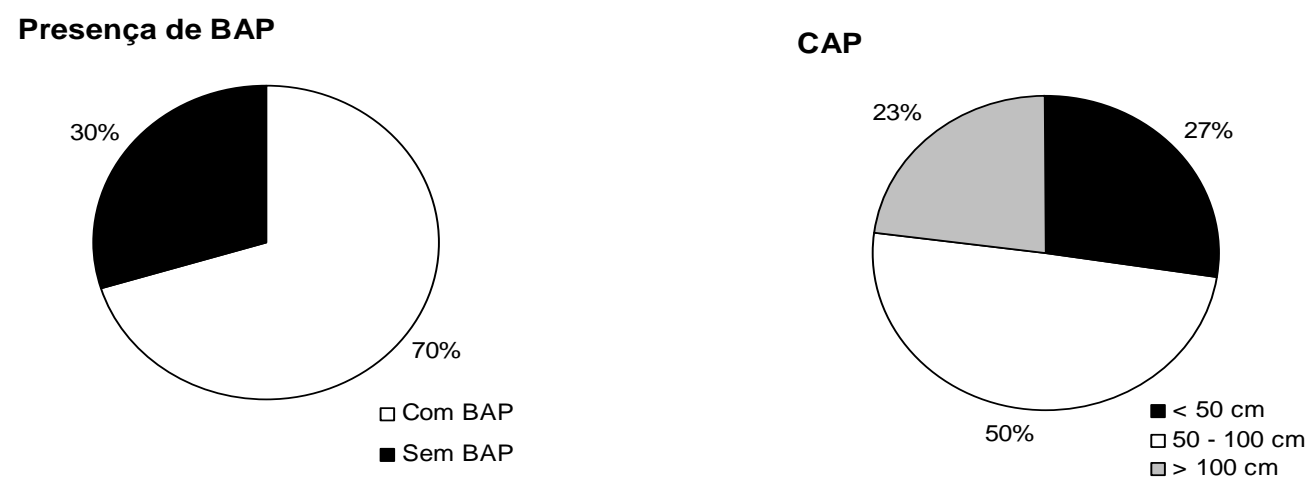

Figura 8 - Presença de bifurcação à altura do peito (BAP) e medida de circunferência à altura do peito (CAP) das árvores de calçada do bairro Santa Cecília - Piracicaba - SP, em 2001

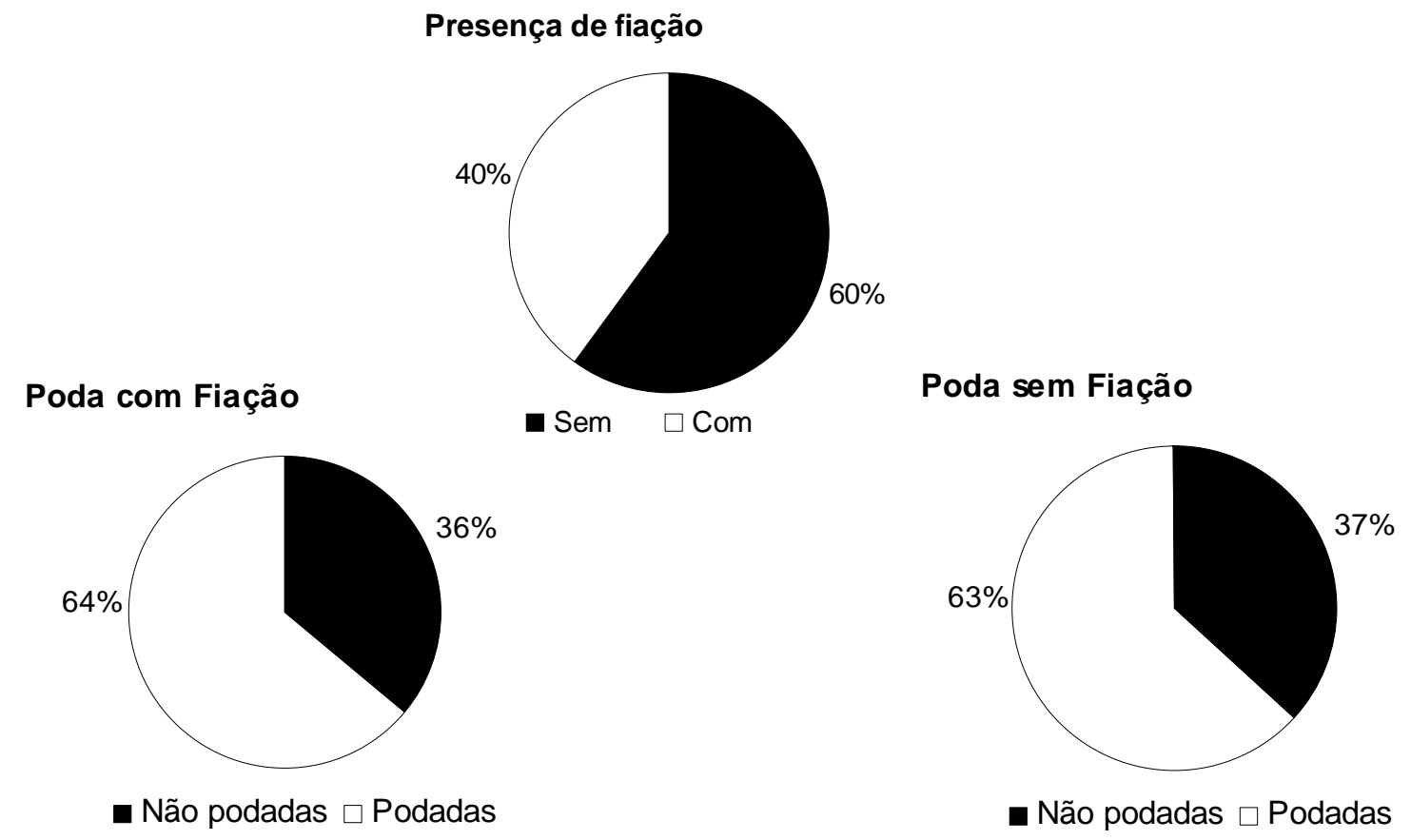

Figura 9 - Presença de fiação sobre as calçadas e poda das plantas, com e sem presença de fiação, das árvores de calçada do bairro Santa Cecília, Piracicaba - SP, em 2001 
Percebe-se a realização de podas de condução feitas pela população, inadequadas por falta de acompanhamento do órgão municipal responsável, analisando-se o gráfico de presença de bifurcação após a altura do peito (BAP) (Figuras 8), em que se observa que a ramificação abaixo de $1,30 \mathrm{~m}$ ocorre em $70 \%$ dos casos, contrariando as normas técnicas de condução de copa. Tanto em indivíduos adultos, quanto em mudas, o ideal é que a condução leve a uma ramificação acima de $1,80 \mathrm{~m}$. Observa-se, também, que as medidas de CAP (Figura 8) de plantas que tiveram sua ramificação conduzida acima de $1,30 \mathrm{~m}$, referentes a circunferências entre $50 \mathrm{~cm}$ e $100 \mathrm{~cm}$, perfazem $50 \%$ do total. Em muitos casos, essas plantas são arbustos, o que fica claro quando se observa que o estrato arbustivo é bem representado no bairro, totalizando 39\% do total da arborização (item 4.1 - Figura 5). Arbustos, por definição, são plantas que possuem uma capacidade de se ramificar desde a base, daí sempre necessitarem de poda de manutenção.

Em $60 \%$ dos quarteirões avaliados, havia presença de fiação (Figura 9). A poda de árvores, devido à presença de fiação, também foi avaliada (Figuras 9), sendo que, dos indivíduos arbóreos que se localizavam no lado da rua sem presença de fiação, 63\% sofreram poda, enquanto que, dos indivíduos em baixo de fiação elétrica, 64\% sofreram poda.

As plantas que não receberam poda foram as palmeiras, as mudas de árvores de grande porte, as árvores de pequeno porte e, na maioria da vezes, os arbustos. As espécies podadas apresentaram um maior porcentual de podas realizadas com sucesso e um menor número de espécies com podas inadequadas.

Dos exemplares cuja CAP foi medida por estar com a ramificação acima de $1,30 \mathrm{~m}$, a metade apresentava um valor de CAP abaixo de 
$50 \mathrm{~cm}$, o que demonstra a presença de arbustos e árvores de pequeno porte, mesmo em locais sem fiação (Figura 8).
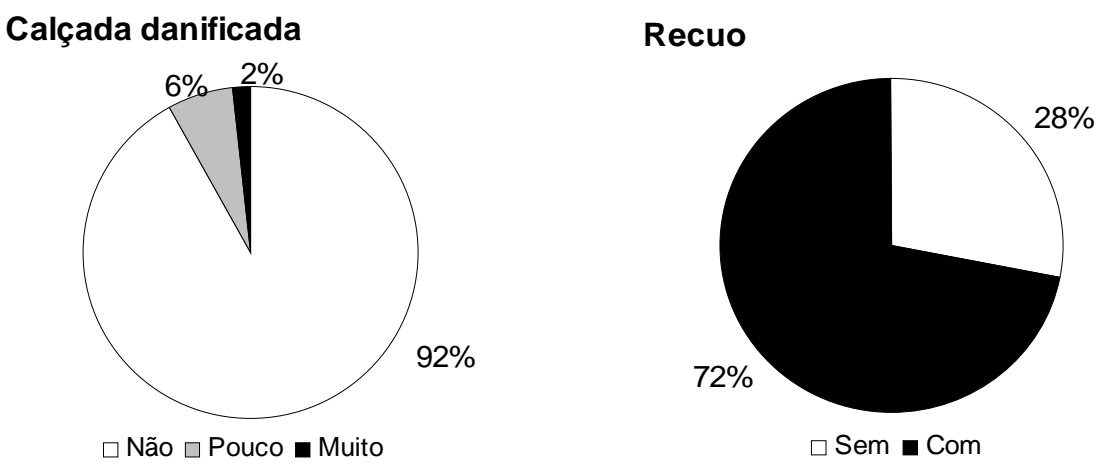

Figura 10 - Presença de calçadas inadequadas e de recuo das residências na arborização das calçadas do bairro Santa Cecília, Piracicaba - SP, em 2001

O espaço fisico para a árvores também foi avaliado. Quanto às calçadas (Figura 10), não houve grandes prejuízos à sua integridade, isto somente ocorreu em alguns casos em que o tamanho do canteiro era inadequado para o diâmetro do fuste. Em outros casos, havia calçadas verdes, o que facilitou o desenvolvimento normal das raízes, sem que estas precisassem procurar a superficie do solo. Já a análise do recuo das residências mostra que $72 \%$ dessas não apresentaram recuo, esse fato não causou grandes problemas à arborização, mas restringiu a possibilidade de uma maior gama de espécies serem utilizadas. Por outro lado, $28 \%$ das residências não respeitaram o recuo exigido por lei, dificultando a implantação e o desenvolvimento satisfatório das árvores.

Na Figura 11, são representadas as alturas e os diâmetros das árvores em 2001 e 2003. As árvores adultas já existentes e as mudas somaram uma porcentagem de $65 \%$ de individuos com altura da copa até $6 \mathrm{~m}$ ) (fiação secundária). Mesmo que se considere que há um bom porcentual de mudas, a presença de árvores de baixo porte é nítida em 
campo. Observando-se o diâmetro, nota-se que há uma parte das árvores de porte baixo que possui um valor mediano ( $3 \mathrm{~m}$ a $6 \mathrm{~m})$, em comparação à grande maioria que é de porte baixo e diâmetro menor que $3 \mathrm{~m}$.
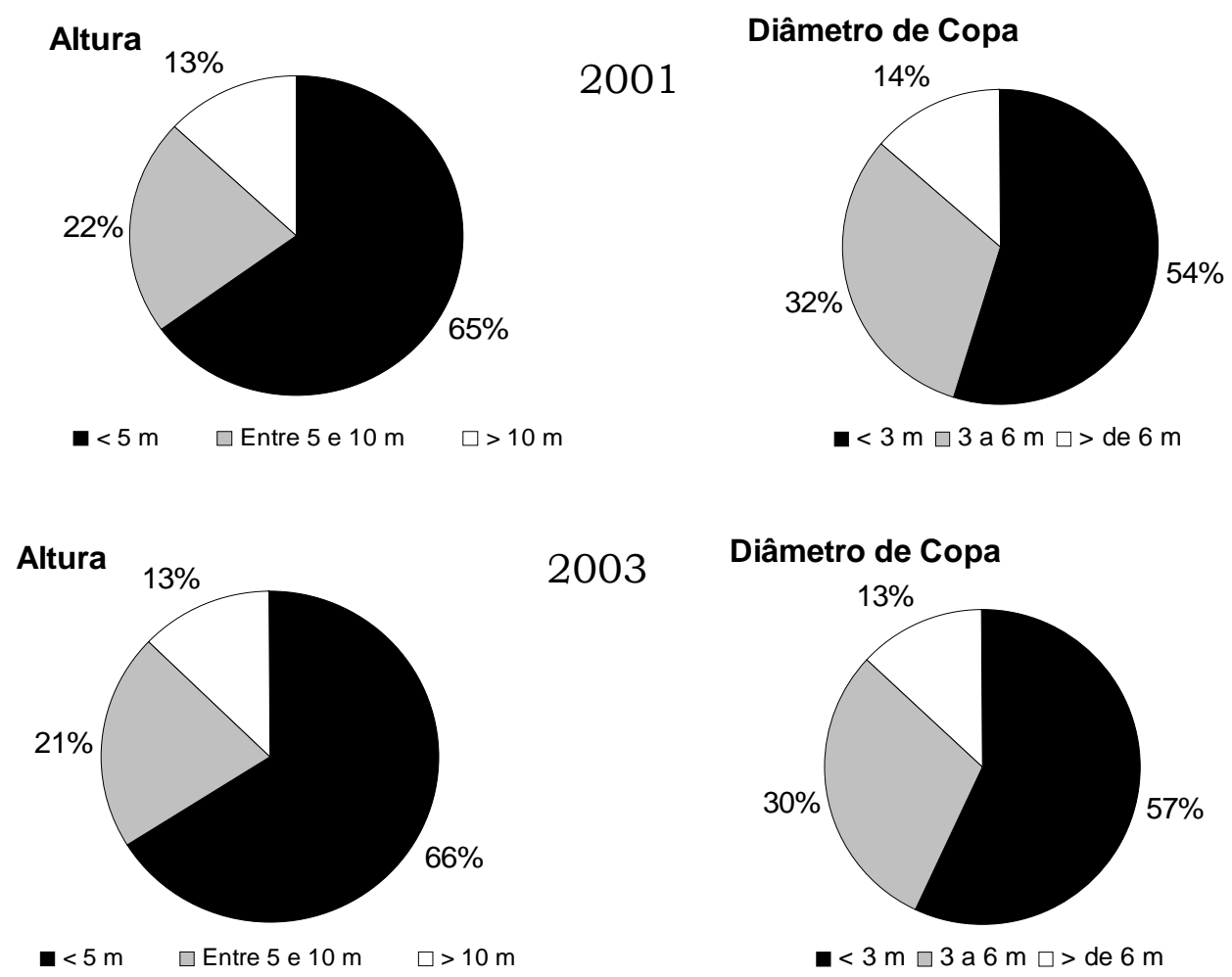

2003

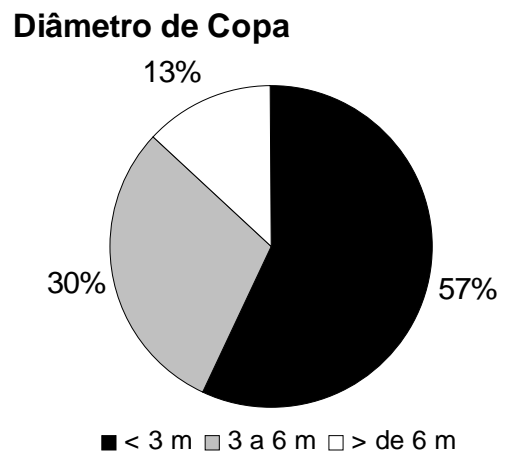

Figura 11 - Altura e diâmetro de copa das árvores de calçadas do bairro Santa Cecília, Piracicaba, SP, em 2001 e 2003

Em 2001, a altura e o diâmetro médio foram de: 4,58m e 3,06m, respectivamente; em 2003, a altura e o diâmetro foram de: 4,42m e 2,99m, respectivamente. Comparando-se a evolução da média de altura da arborização viária e a média do diâmetro de sua copa, observa-se que houve um aumento de $1 \%$ no porcentual de árvores até a altura de $5 \mathrm{~m}$ (fiação secundária), enquanto que houve uma diminuição de $1 \%$ na 
altura entre $5 \mathrm{~m}$ e $10 \mathrm{~m}$ (entre fiação secundária e primária). Já a altura acima de $10 \mathrm{~m}$ (fiação primária) permaneceu inalterada. Por outro lado, quando se avalia a evolução do diâmetro entre 2001 e 2003, nota-se que houve uma diminuição desse parâmetro em alguns casos. A média dos diâmetros aumentou de $54 \%$ para $57 \%$ na classe menor que $3 \mathrm{~m}$ e, nas classes entre $3 \mathrm{~m}$ e $6 \mathrm{~m}$ e maior que $6 \mathrm{~m}$, diminuiu em $2 \%$ e $1 \%$, respectivamente.

A diminuição da altura pode ser explicada ao constatarmos que, nos dados de amostragem aleatória, houve um aumento do número de árvores de 890 para 985 (Tabelas 4 e 6), evidenciando o aumento do número de mudas. Por outro lado, a diminuição da altura não se dá na mesma proporção, porque algumas árvores cresceram. Com relação ao diâmetro da copa, não há um aumento proporcional ao aumento do número de árvores, devido às podas que diminuem a copa das árvores.

O manejo das árvores muitas vezes é inadequado: as podas, em grande parte, nem sempre são necessárias, principalmente do lado sem fiação. Provavelmente, com a retirada de árvores de grande porte e sua substituição por aquelas de porte mais baixo, seriam apenas necessárias podas de formação, até que as plantas fossem consolidadas. A poda de rebaixamento de copa diminui a altura da árvore e, assim, os benefícios inerentes à arborização urbana, como, por exemplo, conforto térmico, também serão reduzidos na mesma proporção.

As podas são incorretas, por adoção de práticas inadequadas, como citado anteriormente, em desacordo com os preceitos da fisiologia vegetal, o que facilita a entrada de fungos e outros predadores. Essas podas, muitas vezes, descaracterizam a arquitetura da planta, desequilibrando-a e aumentando os riscos de queda.

Por serem as podas também de responsabilidade das concessionárias de energia elétrica, até pouco tempo eram feitas sem 
acompanhamento técnico. Hoje, exige-se o acompanhamento de um técnico especializado para supervisionar esse serviço. Dessa forma, espera-se que aumente o bom senso na execução de podas pelas concessionárias de energia.

A prefeitura municipal poda eventualmente as árvores, mas, nesse caso, não se nota a realização de podas de condução em arbustos, o que os deixa com um formato que não se adapta a calçadas.

Nota-se, pelo levantamento realizado no bairro, que não houve um planejamento da arborização urbana por parte da prefeitura. As árvores, em sua grande maioria, são plantadas pelos próprios moradores, sem critério pré-estabelecido.

$\mathrm{O}$ fato de o bairro estar inserido em zonas residenciais ZR3 e ZR4, onde os recuos mínimos exigidos por lei são menos restritivos, favorece a implantação de construções mais adensadas, diminuindo a possibilidade de haver uma boa área para exploração vegetal e, em conseqüência, comprometendo a qualidade de vida.

Em termos de comportamento da população que habita o local estudado, de acordo com informações colhidas verbalmente, verifica-se que muitas das atitudes tomadas pelos moradores vêm da necessidade de aproximação com a natureza. Daí as iniciativas de plantio e podas pelos próprios moradores, o que causa uma falta de padronização dos tratamentos dados às árvores. Práticas como as de poda do ramo apical são muito difundidas entre eles, ao longo do tempo, mesmo sem haver necessidade. Além disso, criou-se uma aversão da população pela presença de árvores em calçadas, por queda de folhas, interrupção no fornecimento de energia elétrica ou outros possiveis acidentes. A conseqüência é que o plantio de árvores é rejeitado por grande parte da população. 
A somatória de fatos isolados acarreta problemas graves para a administração pública, que é responsável por proporcionar uma melhor qualidade de vida aos habitantes. A cobrança dos ambientalistas e dos próprios moradores é muito grande, embora suas contribuições individuais sejam muito pequenas.

Essa situação demanda implantação de programas de educação ambiental por parte do poder público e de diversos ramos da sociedade, com a atuação de "associações de amigos de bairros", "ONGs", entre outras, junto aos moradores.

Em relação às espécies que estão sendo plantadas, quase a totalidade é de porte médio a baixo, algumas até arbustivas, dificultando, assim, uma arborização urbana que traga principalmente benefícios relativos ao conforto termo-acústico, à sombra e ao bem-estar da população. Muitas vezes, os arbustos ainda causam prejuízos, pois não são corretamente conduzidos, tornando-se verdadeiras moitas que prejudicam a passagem de pedestres pela calçada.

$\mathrm{Na}$ área estudada, notam-se variações no tocante ao recuo das residências, desde moradias sem recuo, até aquelas que os possuem de forma correta.

Foi observado alto número de espécies arbustivo - arbóreas de pequeno porte em frente de lotes com grande recuo, mostrando que poderia ter-se feito plantio de espécies de porte maior. Isso também é um reflexo da falta de planejamento do poder público para o local. As copas das espécies citadas são pequenas e não propiciam um sombreamento suficiente.

O Brasil possui grande possibilidades botânicas e paisagisticas, abrigando imenso número de espécies de árvores com copas densas que fornecem um bom sombreamento, interferindo positivamente no microclima. Em cidades como Piracicaba, que chega a ter temperaturas 
variando de $35^{\circ} \mathrm{C}$ a $38^{\circ} \mathrm{C}$ no verão, o plantio de espécies de maior porte, além das nativas ainda não utilizadas, poderia ser feito, principalmente, em bairros em formação, possibilitando as mais variadas composições.

A arborização pode exercer importante papel no clima urbano, em três níveis: micro, meso e macroclima. É possível utilizar o sombreamento da arborização como meio de controle das adversidades climáticas, termais e hídricas, utilizando-o para incrementar condições de conforto no meio urbano.

Além das características de melhoria das condições de clima local, um fator importante ainda não abordado é o descuido quanto à composição cênica do bairro. Nota-se, claramente, que quando existiu uma homogeneidade em termos de espécie plantada, houve alguma interferência do órgão do município responsável. Contudo, na grande maioria dos plantios, a população utilizou mudas sem qualquer preceito técnico, nem planejamento com relação às outras espécies já plantadas na vizinhança, o que prejudicou o equilíbrio e a estética.

\subsubsection{Piso das calçadas}

Tabela 13. Área permeável nas calçadas dos quarteirões levantados no censo e na amostragem aleatória simples, na arborização urbana do bairro Santa Cecília, Piracicaba - SP, em 2003

\begin{tabular}{ccc}
\hline & Censo & $\begin{array}{c}\text { Amostragem } \\
\text { aleatória simples }\end{array}$ \\
\hline $\begin{array}{c}\text { Total de área permeável } \\
\left(\mathrm{m}^{2}\right)\end{array}$ & 1030,50 & 2227,57 \\
$\begin{array}{c}\text { Porcentagem de área } \\
\text { permeável }\end{array}$ & 1,69 & 3,66 \\
C.V.(\%) & & 331,36 \\
E.A.(\%) & & 121,00 \\
\hline
\end{tabular}



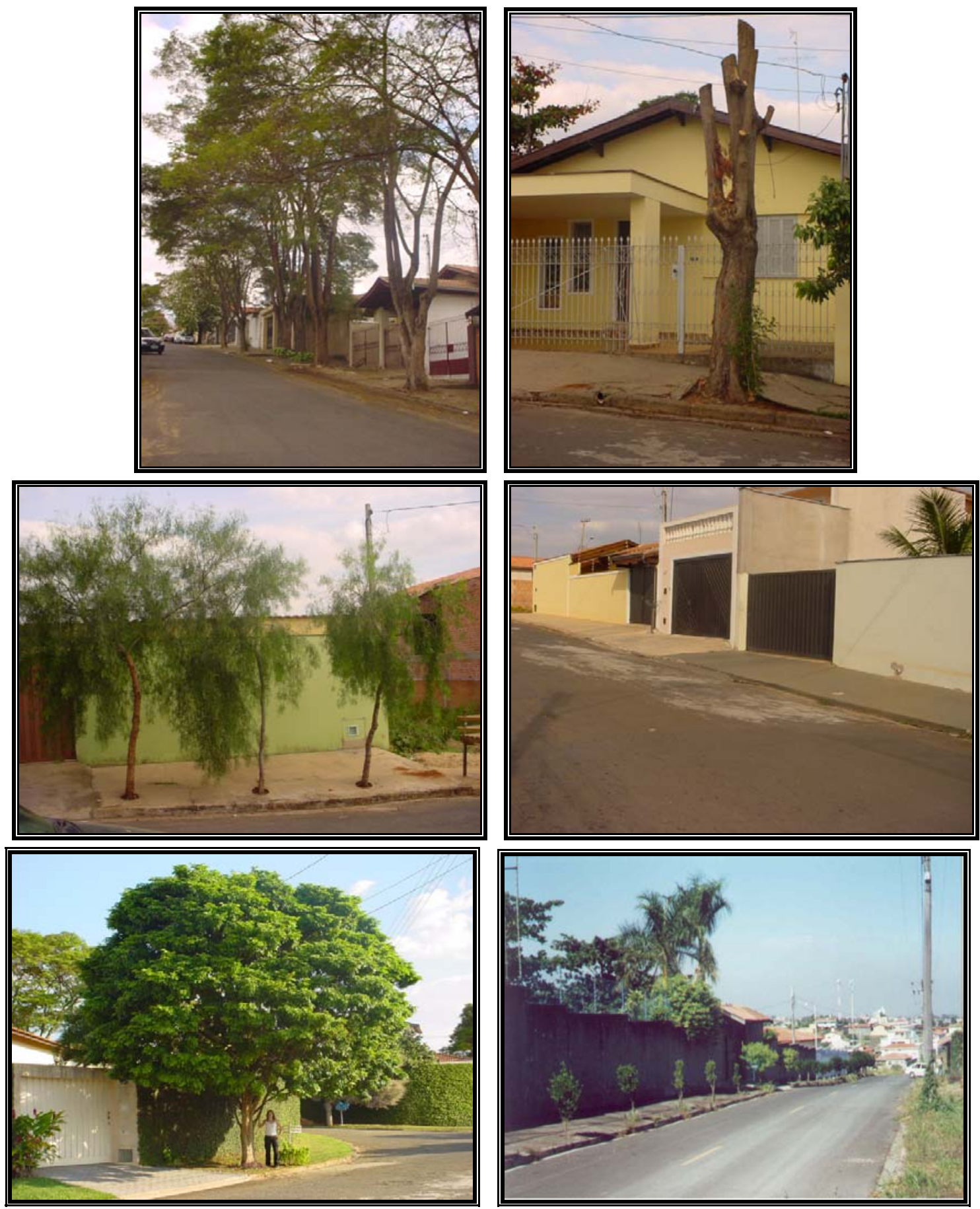

Figura 12 - Arborização de calçadas do bairro Santa Cecília, Piracicaba - SP. A - Sibipiruna (Caesalpinia peltophoroides) com poda adequada; B Sibipiruna com poda drástica; C - plantio de Aroeira-salsa com espaçamento inadequado; D - construções novas sem arborização; E - Pau-brasil (Caesalpinia echinata) com calçada verde; F plantio de mudas de falsas-murtas (Murraya paniculata) 
No que se refere à amostragem aleatória para permeabilidade de calçadas, o coeficiente de variação e o erro amostral foram muito altos, o que compromete a utilização desses dados para composição do IQEVUe. Portanto, serão utilizados os dados do censo.

\subsubsection{Espaço verde de acompanhamento viário}

Tabela 14. Medida de áreas do sistema de acompanhamento viário, excluindo as calçadas do bairro Santa Cecília, Piracicaba SP

\begin{tabular}{cccc}
\hline Sistema viário & Planta baixa $\left(\mathrm{m}^{2}\right)$ & Foto aérea $\left(\mathrm{m}^{2}\right)$ & Videografia $\left(\mathrm{m}^{2}\right)$ \\
\hline Canteiro Central 1 & $9.594,50$ & $9.713,42$ & \\
Canteiro Central 2 & & & $8.940,54$ \\
Trevo 1 & $1.411,52$ & $1.429,02$ & $1.390,98$ \\
Trevo 2 & 913,91 & 925,24 & 900,61 \\
Rotatória & $4.923,23$ & $4.984,25$ & $4.851,59$ \\
Total & $16.843,16$ & $17.051,92$ & $16.083,73$ \\
\% em relação à & 1,36 & 1,39 & 1,35 \\
área total & & & \\
\hline
\end{tabular}

As áreas pertencentes ao sistema de acompanhamento viário estão cobertas de grama em sua totalidade, além de possuírem várias espécies arbóreas. 


\section{3 Índice de Espaços Livres de Uso Público (IELUP) e Porcentagem de Espaço Livre de Uso Público (PELUP)}

\subsubsection{Estudo dos espaços livres}

\subsubsection{Formação do bairro Santa Cecília}

O bairro Santa Cecília. estudado para obtenção do Índice de Qualidade do Espaço Verde com função ecológica (IQEVUe), foi formado em etapas e seus limites foram definidos no zoneamento da prefeitura. Por meio do estudo de sucessivas fotografias aéreas, entre 1945 e 1978 (Figuras 13 a 18), procurou-se compreender a formação do bairro.

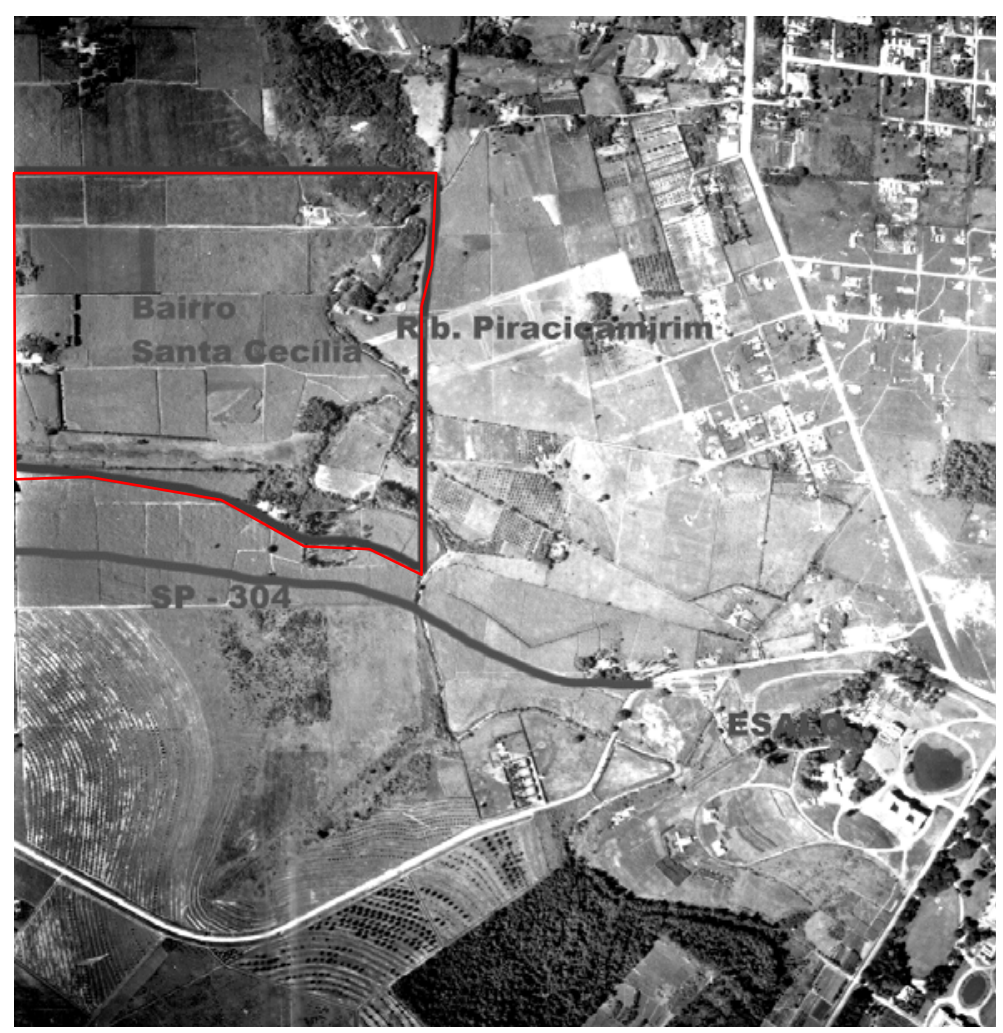

Figura 13 - Fotografia aérea do bairro Santa Cecília, Piracicaba - SP, em 1945 


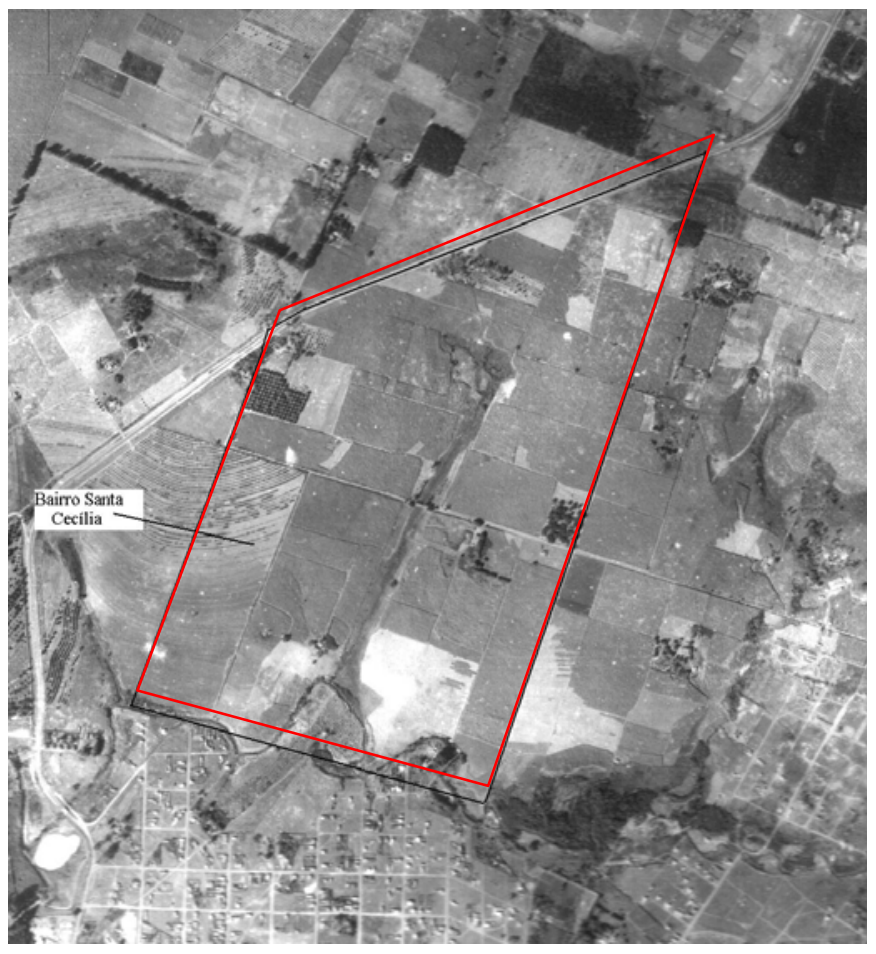

Figura 14 - Fotografia aérea do bairro Santa Cecília, Piracicaba - SP, em 1962

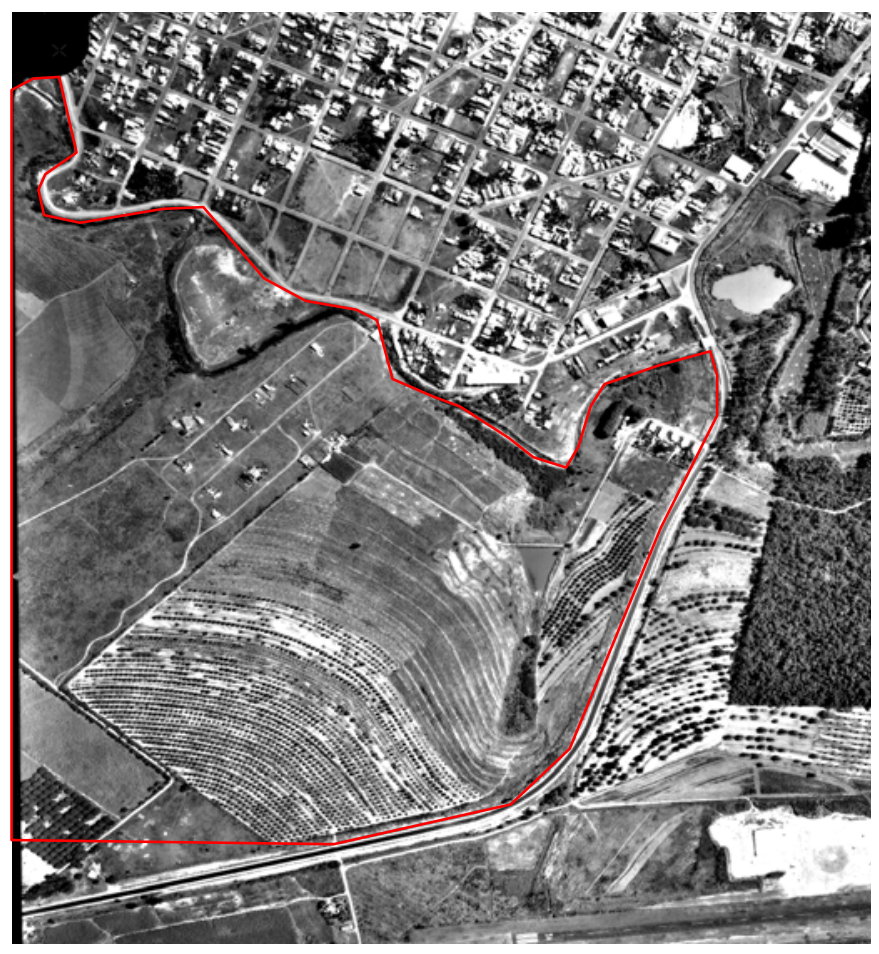

Figura 15 - Fotografia aérea do bairro Santa Cecília, Piracicaba - SP, em 1969 


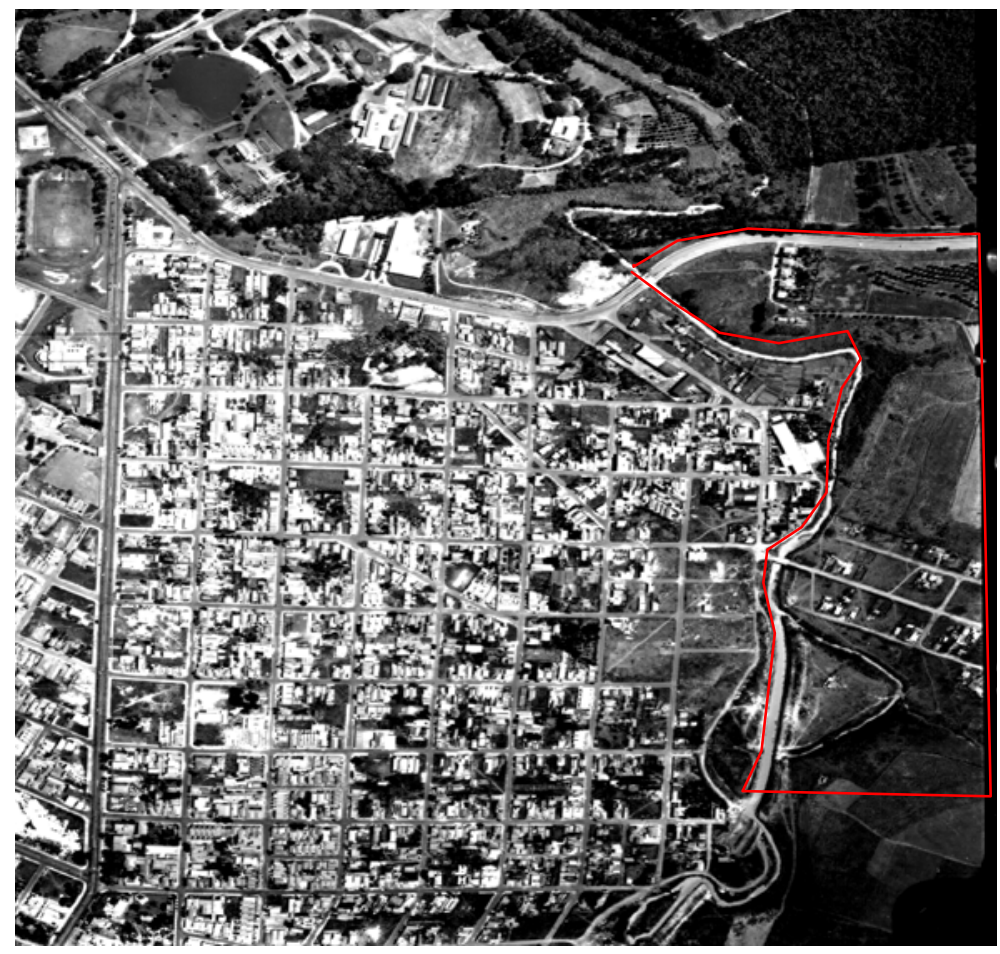

Figura 16 - Fotografia aérea do bairro Santa Cecília, Piracicaba - SP, em 1973

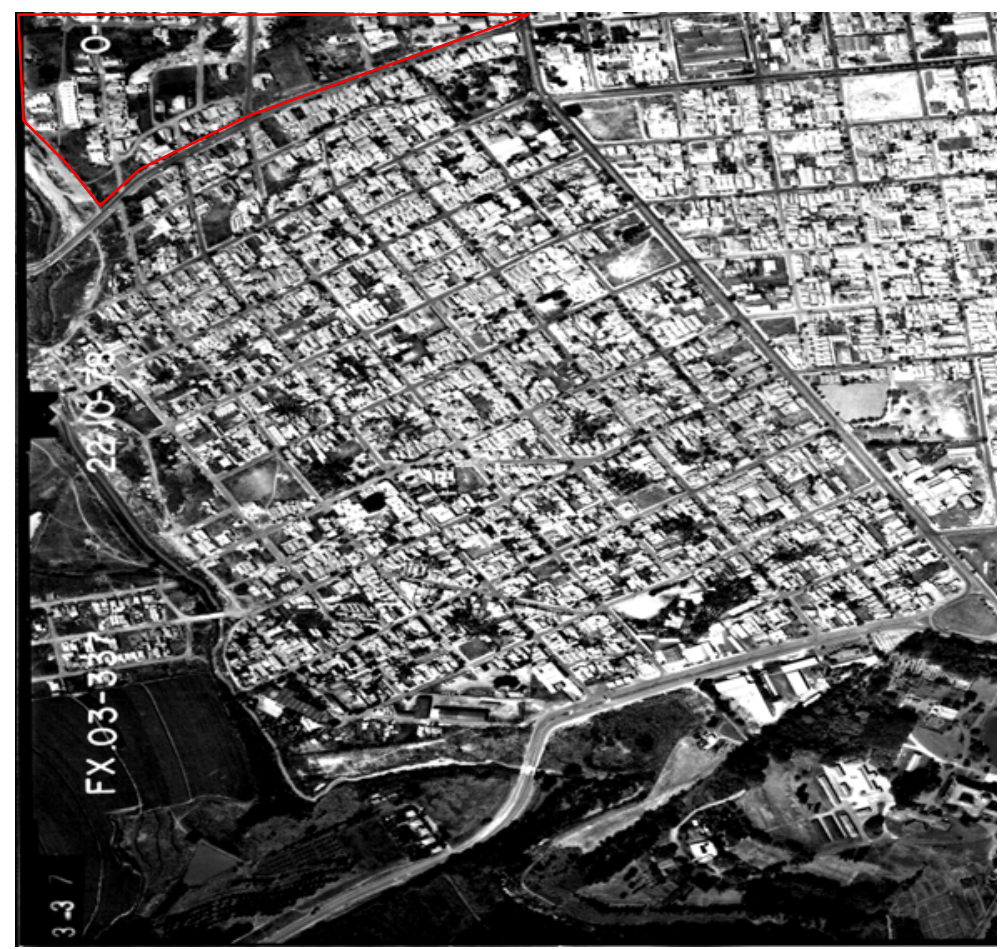

Figura 17 - Fotografia aérea do bairro Santa Cecília, Piracicaba - SP, em 1978 


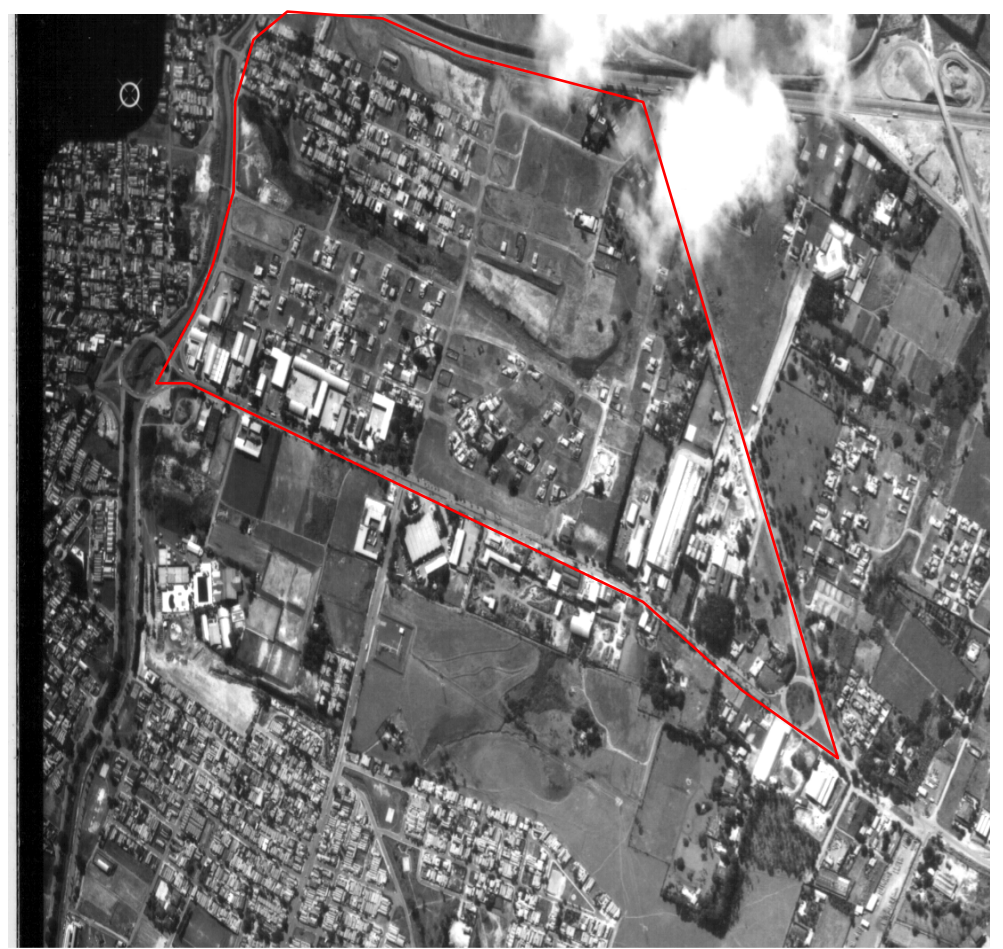

Figura 18 - Fotografia aérea do bairro Santa Cecília, Piracicaba, SP, em 1995

A Figura 13, de 1945 retrata parte da área, onde havia uma fazenda, alguns pomares, plantações anuais e o Ribeirão Piracicamirim com seus meandros. A Figura 14, de 1962, mostra que o quadro permanece inalterado. Em 1969 (Figura 15), observam-se algumas construções residenciais do Loteamento Jardim Brasília, entrecortado pela presença de uma avenida. A Figura 16, de 1973, mostra que o Ribeirão Piracicamirim estava em processo de retificação e a ocupação continuava praticamente a mesma. Em 1978 (Figura 17), a ocupação no loteamento Jardim Brasília já era bem maior e notam-se as primeiras intervenções nos outros loteamentos que estavam sendo criados nessa época. O Ribeirão Piracicamirim já se apresentava retificado. Entre 1978 e 1995, não há fotografias aéreas que registrem a situação do bairro. A 
Figura 18 mostra o bairro em 1995: os loteamentos estão implantados com todas as ruas atuais do bairro, mas ainda com grande quantidade de terreno sem construção.

\subsubsection{Situação atual do bairro Santa Cecília}

O mapa do bairro com seus loteamentos, divisão em glebas e área particulares é exposto na Figura 19.

$\mathrm{O}$ bairro possui características bem distintas em seus loteamentos. No Jardim Brasília, loteamento aprovado na prefeitura municipal em 1970, predominam lotes pequenos (5 X 25m), o mínimo exigido por lei. No Parque Santa Cecília, aprovado em 1975, as características são bem diferentes das do loteamento anterior: os lotes são maiores, as ruas terminam em balões, chamados "cul de sac", o que valoriza o local e traz residentes de maior poder aquisitivo. O Jardim Água Seca, de 1979, possui apenas uma parte inserida nesse bairro, porém, com características similares ao último descrito. O Loteamento Santa Cecília, o mais recente, implantado em 1987, apresenta calçadas de 2,5m com terrenos de $12 \times 20 \mathrm{~m}$, sendo seus moradores também de padrão sócio-econômico elevado. O Recanto Tropical, aprovado em 1980, é um loteamento menor, onde está inserida uma nascente de córrego que deságua no Ribeirão Piracicamirim. 


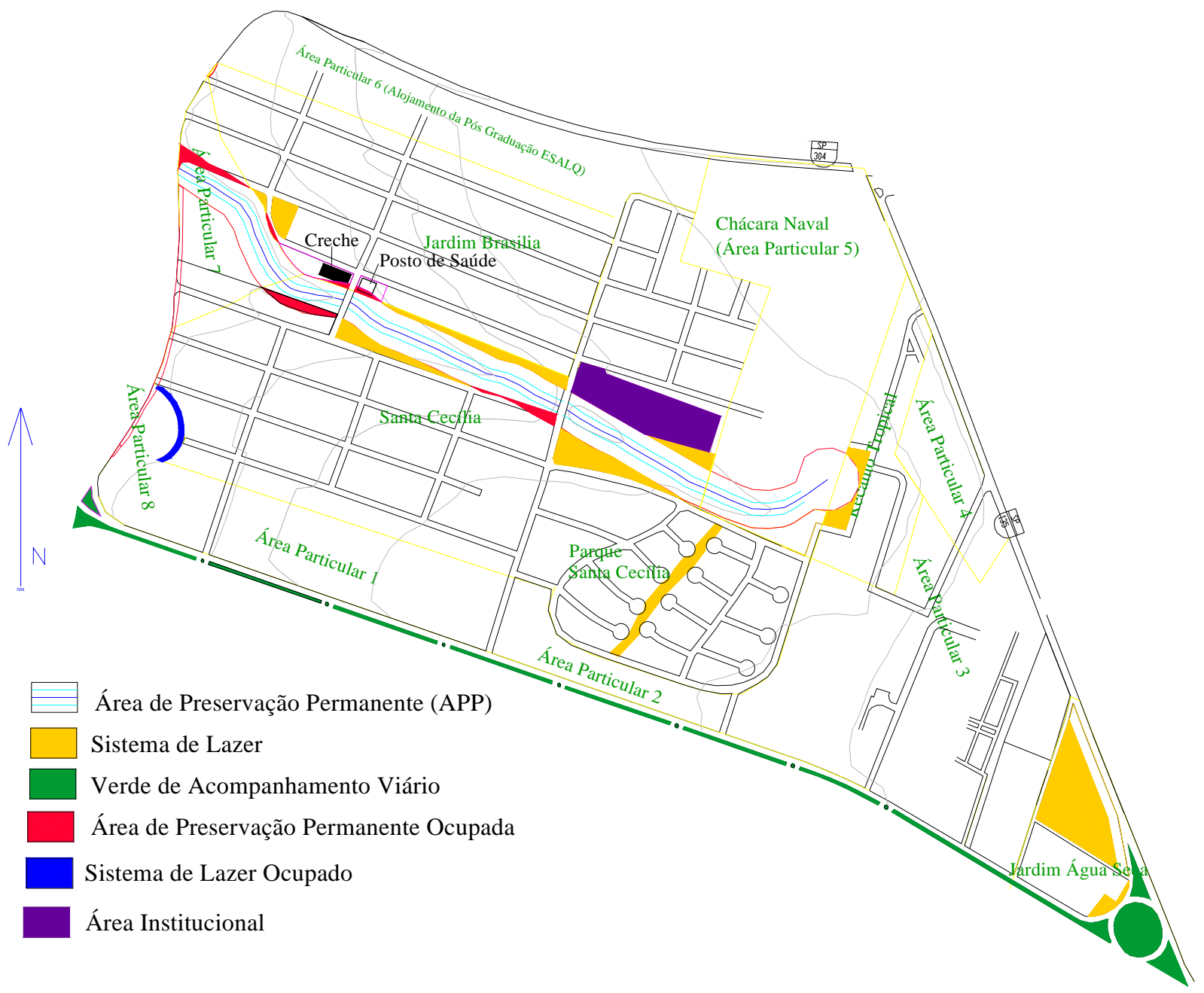

Figura 19 - Loteamentos, divisão em glebas, áreas particulares e espaços livres de uso público do bairro Santa Cecília, Piracicaba - SP 
No bairro, há áreas particulares que não pertencem a nenhum loteamento: invasões, ocupações em remanescentes vegetais, chácaras já existentes no local e divisão em glebas não oficializadas (Chácara Naval). A divisão em glebas é um desmembramento entre as partes, porém, sem registro em cartório. Nesse caso específico, existe, desde 1979, um processo na prefeitura que requer a oficialização de desmembramento, porém incompleto em termos legais, uma vez que, na proposta, não estão contempladas a doação de áreas públicas (sistema de lazer, área institucional, sistema viário, proteção de nascentes e cursos d'água, entre outras), nem a implantação das benfeitorias exigidas por lei e de responsabilidade do loteador (projeto detalhado de loteamento com arruamento, asfalto, galerias pluviais etc).

Uma outra área (Área Particular 5) que não foi legalmente desmembrada é um condomínio fechado, formado por uma série de edifícios construídos alinhados e adensados, de sistema viário extremamente estreito, sem a presença de sistema de lazer ou de área institucional.

De uma forma geral, todos os loteamentos aprovados pela prefeitura foram contemplados com projeto de sistema de lazer e projeto de arborização, que, contudo, ainda não foram implantados.

Quanto a áreas vizinhas (Figura 1), a leste, encontra-se a Escola Superior de Agricultura "Luiz de Queiroz" (Área Particular 6), que funciona como moderador do microclima, pela presença de seus remanescentes de mata e plantações, ainda que não sirva como quebravento, atuação muito necessária no local. Ao norte, está a Vila Independência, um bairro antigo, adensado, formado de residências unifamiliares, com poucos prédios altos e sem nenhum sistema de lazer. O Parque Água Seca, a oeste, e o Perdizes, ao sul, são constituídos de 
chácaras e clubes, possuindo grandes extensões vegetadas com gramineas e árvores e apenas algumas construções.

O tráfego de veículos no interior do bairro é pouco intenso, pois é margeado por artérias de escoamento que concentram o maior fluxo, restando apenas os veículos que acessam o bairro. A presença da Rodovia SP-304 forma uma barreira no lado leste, impedindo que veículos atravessem o bairro, vindos daquela direção. O Ribeirão Piracicamirim, apesar de ter pista que o margeia, possui apenas duas passagens destinadas a veículos, que são as pontes que ligam o bairro à Vila Independência e ao bairro dos Alemães. No lado oeste, a Avenida Prof. Cássio Paschoal Padovani também serve de barreira, pois apresenta grandes extensões de canteiros centrais sem retornos, o que dificulta a travessia. No lado leste, a antiga rodovia para São Paulo, interrompida pelos serviços de terraplanagem da nova SP 304, constitui também um impedimento de acesso ao bairro, servindo, apenas, para chegar a alguns bairros de pequeno porte e alguns clubes.

\subsubsection{Identificação dos espaços livres de uso público}

A identificação dos espaços livres de uso público foi feita a partir do estudo de cada área conforme a designação que constava no cadastro da prefeitura. Em alguns casos, foi feita uma proposta de mudança de denominação da área em função da modificação de sua finalidade. As áreas são expostas como loteamentos e áreas particulares. A Figura 19 mostra a localização desses espaços no bairro.

A - Jardim Brasília

A 1 - Área de Preservação Permanente

Ocupação: mato e algumas árvores. 
> Intervenção: retirada do entulho e plantio de árvores. A área deve ser implementada como um sistema de lazer apropriado para o bairro, já que há muitas residências em volta.

A 2 - Área de preservação permanente em torno do côrrego ocupada

> Ocupação: a área está ocupada com parte de uma creche e parte de um centro comunitário. Esta área foi destinada à função de área verde antes da resolução n. 4 do Conama de 1985, que aumentou a área de preservação permanente (APP, em torno do córrego) de $5 \mathrm{~m}$ para $30 \mathrm{~m}^{1}$. Portanto, parte da creche está em local de APP.

> Intervenção: a sugestão é que, na medida do possível, regularizese a situação da creche, uma vez que ela foi construída antes da resolução de aumentar a faixa de APP.

A 3 - Área institucional construída.

Ocupação: A área foi destinada a lazer, mas está ocupada com uma creche e um centro comunitário com posto de saúde.

> Intervenção: esta é uma área que já está implantada, mas além de ocupar a área de sistema de lazer, avança na área de preservação permanente. Propõe-se que seja mantido o uso e passe a ser considerada como área institucional, já que é o mesmo caso da área A2. A compensação da área de sistema de lazer deve ser feita com a área institucional não construída.

${ }^{1}$ O CONSELHO NACIONAL DO MEIO AMBIENTE - CONAMA, no uso das atribuições que lhe conferem a Lei Federal 6.938, de 31 de agosto de 1981, regulamentada pelo Decreto 99.274, de 06 de junho de 1990 e tendo em vista o disposto em seu Regimento Interno , bem como considerando a necessidade de regulamentar o art. 2 da Lei Federal 4.771, de 15 de setembro de 1965, no que concerne às Áreas de Preservação Permanente, resolve: Art. $1^{\circ}$ Constitui Área de Preservação Permanente a área situada: I - ao longo de curso d'água, com largura mínima, em projeção horizontal, medida a partir do nível mais alto do leito menor, de: a) trinta metros para o curso d'água com menos de dez metros de largura; 
B - Parque Santa Cecília

B 1 - Sistema de lazer

> Ocupação: esta área contínua pode ser dividida em três partes, conforme o seu uso: parte da área não recebe nenhum tratamento paisagístico, com a presença de mato; outra parte apresenta plantio de ipês muito próximos de palmeiras, um tratamento totalmente inadequado, e a terceira parte tem árvores plantadas sem planejamento, mas que estão cumprindo um papel estético e de quebra-vento, como grevilhas, pinus, mangueiras, pitangueiras, palmeiras, entre outras.

Intervenção: pode-se aproveitar o que já foi plantado, sugerir a retirada das plantas inadequadas e reposição de outras que sejam mais compativeis com o local. A reformulação da área deve ser feita sob a orientação da prefeitura.

C - Loteamento Santa Cecília

C 1 - Sistema de lazer

Ocupação: bosque com árvores nativas, próximo à área de preservação.

> Intervenção: manejo das árvores plantadas.

> Observação: na verdade, esta área é uma extensão da APP, já que esta aumentou com a nova lei. Então, passou a ter maior área florestada contínua. Por outro lado, os espaços verdes como áreas verdes concentram-se em um só local do loteamento. A questão que pode ser levantada é se seria mais interessante ter a área de lazer afastada da APP. Nesse caso não, porque há outros sistemas de lazer próximos. 
C 2 - Área de preservação permanente em torno do córrego.

> Ocupação: bosque com árvores nativas e bica d'água. Áreas lindeiras: casas de alto padrão.

> Intervenção: plantio de árvores e manejo das árvores existentes por meio de aproveitamento da regeneração natural.

C 3 - Sistema de lazer remanescente de retificação do Ribeirão Piracicamirim e APP ocupada.

Ocupação: parte da área é designada para sistema de lazer (de n. 7), conforme mapa de Projeto de Loteamento (Loteamento Santa Cecília) e outra parte é remanescente de APP que está invadida com construções. Na planta oficial de aprovação na prefeitura, consta o arruamento de uma forma que não condiz com a realidade em campo. Com a retificação do Ribeirão Piracicamirim, as áreas, antes ocupadas com os meandros do mesmo ficaram desocupadas.

> Intervenção: propõe-se, então, que a prefeitura compense este sistema de lazer com uma outra área do bairro de tamanho semelhante.

C 4 - Área institucional não construída.

> Ocupação: mato e algumas árvores.

> Intervenção: como a área não é construída, como foi previsto inicialmente, propõe-se incorporá-la como espaço verde, já que é contígua à área de lazer à APP e uma vez que já existem, no bairro, áreas institucionais construídas. Desta forma, seria usada também para compensação dos sistemas de lazer ocupados. 
D - Jardim Água Seca

D 1 - Sistema de lazer (Praça Elvira Guardia Mascarin).

> Ocupação: em parte dela já existe um plantio.

> Intervenção: implantar a área com passeios e jardins.

E - Recanto Tropical

E 1 - Sistema de lazer e parte de APP

Ocupação: existe um plantio recente de mudas de árvores nativas. A área está próxima à área de preservação permanente.

> Intervenção: como parte da área passou a fazer parte da APP, ela deve ser toda manejada como mata nativa e com o mínimo de intervenções, para utilização pela população.

E 2 - Área de preservação permanente com nascente

> Ocupação: área particular com algumas árvores e uma construção para proteção de poço e tanque de água.

> Intervenção: retirada da cobertura do poço e do tanque e revitalização da nascente com plantio de árvores nativas.

F - Âreas particulares

F 1 - Área de preservação permanente em torno do córrego.

$>$ Ocupação: mato e mudas de árvores nativas.

> Intervenção: continuar o plantio de árvores da mata ripária.

F 2 - Espaço verde remanescente de retificação do Ribeirão Piracicamirim.

> Ocupação: mato e algumas árvores.

> Intervenção: manter como espaço verde com possibilidade de manejo para contribuição à revegetação do bairro. 
F 3 - Área de preservação permanente

> Ocupação: em parte, ela está ocupada por um depósito de construção com montes de areia e pedras. Próximo ao córrego, está a área de preservação permanente referente ao córrego do bairro. Em outra parte, há ocupação por uma borracharia e uma funilaria, dentro da área de preservação permanente remanescente da retificação do Ribeirão Piracicamirim.

$>$ Intervenção: propõe-se a retirada do depósito para que se respeite a área de preservação permanente. Quanto à borracharia e à funilaria ali presentes, propõe-se que se legalizem suas áreas, por meio do enquadramento na legislação, uma vez que já existe a avenida separando-as do Ribeirão Piracicamirim.

O estudo dessas áreas permitiu agrupar os espaços livres para composição do IELUP, o que está exposto na Tabela 15. 
Tabela 15. Espaços livres de uso público presentes nos loteamentos e áreas particulares do bairro Santa Cecília, Piracicaba - SP, medidos na planta baixa, na fotografia aérea e na videografia

\begin{tabular}{|c|c|c|c|}
\hline Tipo de Espaço Livre & $\begin{array}{c}\text { Planta baixa }\left(\mathrm{m}^{2}\right) \\
(1995)\end{array}$ & $\begin{array}{c}\text { Foto aérea }\left(\mathrm{m}^{2}\right) \\
(2000)\end{array}$ & $\begin{array}{c}\text { Videografia }\left(\mathrm{m}^{2}\right) \\
(2003)\end{array}$ \\
\hline \multicolumn{4}{|c|}{ JARDIM BRASÍLIA } \\
\hline Sistema de lazer & $1.619,00$ & $1.599,18$ & $1.556,62$ \\
\hline APP ocupada & 563,04 & 556,15 & 541,34 \\
\hline Institucional construída. & $3.616,23$ & $3.571,96$ & $3.476,89$ \\
\hline Área total & $149.010,00$ & $147.185,70$ & $143.268,28$ \\
\hline \multicolumn{4}{|c|}{ PARQUE SANTA CECÍLIA } \\
\hline Sistema de lazer & $2.597,50$ & $2.565,70$ & $2.497,41$ \\
\hline Área total & $111.102,72$ & $109.742,51$ & $106.821,66$ \\
\hline \multicolumn{4}{|c|}{ LOTEAMENTO SANTA CECÍLIA } \\
\hline Sistema de lazer & $12.388,00$ & $12.236,34$ & $11.910,66$ \\
\hline Instit. não construída & $16.668,36$ & $16.464,29$ & $16.026,09$ \\
\hline APP & $37.971,04$ & $37.506,17$ & $36.507,92$ \\
\hline APP ocupada & $2.214,23$ & $2.187,12$ & $2.128,91$ \\
\hline Área total & $2.214,23$ & $2.187,12$ & $2.128,91$ \\
\hline \multicolumn{4}{|c|}{ RECANTO TROPICAL } \\
\hline Sistema de lazer & $2.059,00$ & $2.033,79$ & $1.979,66$ \\
\hline APP & $2.390,00$ & $2.360,74$ & $2.297,91$ \\
\hline Área total & $38.282,00$ & $37.813,32$ & $36.806,90$ \\
\hline \multicolumn{4}{|c|}{ JARDIM ÁGUA SECA } \\
\hline Sistema de lazer & $16.835,96$ & $16.629,84$ & $16.187,23$ \\
\hline Área total & $50.783,64$ & $50.161,91$ & $48.826,82$ \\
\hline \multicolumn{4}{|c|}{ ÁREAS PARTICULARES } \\
\hline APP & $37.697,21$ & $37.235,69$ & $36.244,65$ \\
\hline APP ocupada & $\begin{array}{c}3.895,95 \\
\text { TOTAL }\end{array}$ & $3.848,25$ & $3.745,83$ \\
\hline Sistema de Lazer & $35.830,46$ & $35.391,79$ & $34.449,83$ \\
\hline Instit. não construída & $16.668,36$ & $16.464,29$ & $16.026,09$ \\
\hline Institucional construída & $41.587,27$ & $41.078,12$ & $39.984,81$ \\
\hline APP & $78.058,25$ & $77.102,60$ & $75.050,48$ \\
\hline APP ocupada & $9.726,41$ & $9.607,33$ & $9.351,63$ \\
\hline
\end{tabular}




\subsubsection{Cálculo do Índice de Espaços Livres de Usos Públicos (IELUP) e da Porcentagem de Espaço Livre de Uso Público (PELUP)}

O cálculo do Índice de Espaços Livres de Uso Público (IELUP) foi feito para dois anos, visando a ter uma noção da evolução da disponibilidade dos espaços livres, conforme o aumento da população. Utilizaram-se os censos de 1990 (IBGE, 1991) e de 2000 (IBGE, 2001). Entre os anos de 1990 e 2000, não houve modificações dos espaços livres disponíveis, conforme estudo histórico do item 4.3.1; portanto, utilizar-se-ão os dados levantados para os dois anos, expostos na Tabela 15.

Em 1990, o número de habitantes, no bairro, era de 1931 e, em 2000, era 3016 .

Os resultados do calculo do IELUP no bairro são apresentados na Tabela 16.

Cabe lembrar que, para a realização dos cálculos, utilizou-se a legislação atualizada, ou seja, em locais onde o sistema de lazer teve sua finalidade modificada, a área referente não entrou no cálculo.

A comparação com outros índices merece uma atenção especial, uma vez que várias terminologias são utilizadas por diferentes trabalhos. Conforme tabela organizada por Guzzo (1998), outras denominações e métodos foram adotados para identificar espaços livres, como: Espaços Livres Urbanos (Escada, 1992) e Áreas Públicas Livres de Edificações (Goya, 1990). Aqui, adota-se a terminologia de Cavalheiro (1996), ou seja, compara-se o IELUP (formado por sistema de lazer) com os índices para o distrito de Santa Cecília, no Município de São Paulo (Nucci, 1996) e com os índices obtidos para Ribeirão Preto-SP (Guzzo, 1999), que utilizaram a mesma terminologia. 
Tabela 16. Tipos de Índice de Espaço Livre de Uso Público (IELUP) medidos na planta baixa, na fotografia aérea e na videografia do bairro Santa Cecília, Piracicaba - SP

\begin{tabular}{cccc}
\hline Tipos de IELUP & $\begin{array}{c}\text { Planta baixa } \\
\left(\mathrm{m}^{2} / \text { hab }\right)\end{array}$ & $\begin{array}{c}\text { Foto aérea } \\
\left(\mathrm{m}^{2} / \text { hab }\right)\end{array}$ & $\begin{array}{c}\text { Videografia } \\
\left(\mathrm{m}^{2} / \text { hab }\right)\end{array}$ \\
\hline $\begin{array}{c}\text { Somente Sistema de lazer } \\
\text { Sistema de lazer + área } \\
\text { Institucional não } \\
\quad \text { construída }\end{array}$ & 18,990 & & 17,84 \\
$\begin{array}{c}\text { Sistema de lazer + área } \\
\text { Institucional não } \\
\text { construída + APP }\end{array}$ & 67,19 & 27,44 & 26,14 \\
$\quad 2.61$ & 68,23 & 65,01 \\
$\begin{array}{c}\text { Somente Sistema de lazer } \\
\text { Sistema de lazer + área } \\
\text { Institucional não } \\
\text { construída }\end{array}$ & 11,88 & 11,99 & 11,42 \\
$\begin{array}{c}\text { Sistema de lazer + área } \\
\text { Institucional não } \\
\text { construída + APP }\end{array}$ & 17,41 & 17,57 & 16,74 \\
\hline
\end{tabular}

Os dados levantados por Guzzo (1999) mostram que os valores aqui encontrados estão bem acima dos expostos para Ribeirão Preto. De modo geral, Guzzo (1999) encontrou um IELUP de $4,92 \mathrm{~m}^{2} / \mathrm{hab}$, considerando áreas implantadas e não implantadas. No Distrito de Santa Cecília (São Paulo-SP), Nucci obteve um IELUP de $0,92 \mathrm{~m}^{2} /$ hab.

A comparação pode ser mais refinada se os dados da Tabela 15 forem colocados em termos de porcentual em relação à área total do bairro (Tabela 17) e confrontados com o Subsetor N5 de Ribeirão Preto, constituído por um bairro distante do centro, com uma área predominantemente residencial, diferente do centro daquela cidade de 
Ribeirão Preto e do Distrito de Santa Cecília (São Paulo-SP), que são áreas mais antigas, de maior valor especulativo e, conseqüentemente, de maior adensamento.

Tabela 17. Tipos de Porcentagem de Espaço Livre de Uso Público (PELUP) do bairro Santa Cecília, Piracicaba - SP

\begin{tabular}{cc}
\hline Somente Sistema de lazer & 2,89 \\
Sistema de lazer + área Institucional não construída & 4,23 \\
Sistema de lazer + área Institucional não construída & 10,52 \\
+ APP & \\
\hline
\end{tabular}

O Setor N5 de Ribeirão Preto possui 6,34\% de espaços livres de uso público correspondente a um índice de $9,58 \mathrm{~m}^{2} / \mathrm{hab}$, enquanto que para o caso aqui estudado, 2,89\% corresponde a um IELUP atual de $11,82 \mathrm{~m}^{2} /$ hab $, 11,9 \mathrm{~m}^{2} /$ hab e $11,42 \mathrm{~m}^{2} / \mathrm{hab}$, dependendo do método, se medido pela planta baixa, pela fotografia aérea ou pela videografia, respectivamente. Portanto, a densidade populacional é muito importante, como também constatado por Guzzo (1999) e por Oliveira (1996).

A avaliação para o PELUP, feita em dois anos, mostrou claramente a influência do aumento de população para que diminuísse o indice.

Apesar de não ser novo e estar localizado próximo à região central, o bairro Santa Cecília ainda se encontra em fase de ocupação, fato de difícil explicação, uma vez que outras áreas próximas, que foram implantadas mais recentemente, estão tendo um crescimento bem mais rápido. $\mathrm{O}$ bairro foi ocupado em etapas, porém, ainda não está 
totalmente implantado, o que leva a crer que a população deva aumentar, embora ainda não se constate uma tendência de construções com maior adensamento, como prédios de apartamento.

As comparações, aqui realizadas, são feitas com o intuito de se ter uma idéia dos espaços livres que podem ser utilizados como espaços verdes pela população. Caso se leve em consideração a inclusão da área institucional não construída como sendo um espaço livre, o PELUP sobe de $2,89 \%$ para $4,23 \%$. Por outro lado, incluir as áreas de preservação permanente como espaço livre, elevaria o PELUP para 10,52\%, um aumento de mais de 3 vezes, mas o manejo para essa área não poderia ser o mesmo de outras áreas de lazer. Desta forma, a acessibilidade ficaria comprometida, contrariando os princípios para espaço livre público.

Como o enfoque principal desse trabalho é abordar a questão ecológica do verde urbano, a acessibilidade das áreas é, então, um fator apenas coadjuvante em nosso trabalho, porém, não menos importante. Qualquer manejo de preservação das áreas que se utilize não pode deixar de lado a questão do lazer. Por mais que uma área urbana esteja sendo vista como uma forma de melhoria da Ecologia Urbana, nunca se deve deixar de lado o fator humano como colaborador para sua conservação e interventor nas condições naturais.

Apesar dos loteamentos examinados terem seguido a legislação, a falta de espaços destinados ao lazer da população é uma constante, pois as áreas previstas no loteamento são lindeiras às Áreas de Preservação Permanente em quase sua totalidade. Com as mudanças na legislação do Código Florestal em 1989 (Brasil, 1989), relacionadas à largura das faixas determinadas para proteção de mananciais, as áreas de lazer tiveram sua finalidade modificada e ficaram restritas a estreitas faixas vizinhas às APPs. 
De uma forma geral, em grande parte dos loteamentos, tanto nos antigos, quanto nos novos, observam-se calçadas estreitas com prédios construídos sem o devido recuo, sistemas de lazer mal localizados e de uso restrito, áreas de nascente e de várzeas aterradas. Esses efeitos são resultantes da busca desenfreada de economia no empreendimento e da falta de preocupação com o bem-estar de quem ali vai habitar.

A Lei 6766/79 (Brasil, 1979), que dispõe sobre o parcelamento de solo urbano, tornou-se um importantíssimo instrumento jurídico e de planejamento para o desenvolvimento das cidades. Além de definir claramente em quais situações de risco ambiental não é permitido o parcelamento do solo, há a obrigatoriedade de, no mínimo, 35\% da área loteada ser destinada à implantação de áreas públicas, tais como: sistema de circulação, implantação de equipamentos urbanos e comunitários (escolas, creches, centros de saúde, sede de bairros, entre outros), bem como espaços livres de uso público (sistemas de lazer). Houve, portanto, uma revolução no que se refere ao planejamento de centros urbanos, gerando uma situação de sistemas de lazer incrustados em meio a lotes.

Mesmo após a criação dessa Lei (6766/79), muitas áreas destinadas ao lazer tiveram sua finalidade modificada, sendo doadas a igrejas, clubes, associações, entre outras, ditas "obras comunitárias". Até 1989, um grande número de doações foram feitas causando um déficit de sistemas de lazer que só foi sanado com o Artigo 180 da Constituição do Estado de São Paulo: "as áreas definidas em projeto de loteamento como áreas verdes ou institucionais não poderão, em qualquer hipótese, ter sua destinação, fim e objetivos, originalmente estabelecidos, alterados".

Um outro problema ainda não resolvido refere-se à escolha da parcela a ser destinada para a finalidade de lazer, dentro da área a ser 
loteada. Normalmente, o que ocorre é que as áreas eleitas são as piores do terreno, de solos rasos (que dificultam a construção), ingremes e, ainda, como a Lei 9.785 de 1999 (Brasil, 1999) não determina se os 10\% do loteamento destinados ao sistema de lazer podem ser divididos ou não, os loteadores deixam, para tal sistema de lazer, sempre áreas onde o espaço não é suficiente para a locação de lote.

No município de Piracicaba, a Lei 2643 de 1985 (Piracicaba, 1985), em seu Artigo $18^{\circ}$, Parágrafo $4^{\circ}$, determina que um técnico da prefeitura municipal de Piracicaba é quem designará, na área a ser loteada, aquela parte destinada ao lazer.

Quando se fala em área de proteção permanente, definida pela Lei Federal 4.771 de 1965 (Brasil, 1965), a situação agrava-se ainda mais. Pode-se observar, nas cidades, corpos d'água totalmente impermeabilizados e ainda canalizados, nascentes aterradas, desrespeitando totalmente os preceitos ecológicos. No bairro Santa Cecília, os cursos d'água foram respeitados e reflorestados em parte, embora a nascente não esteja protegida. Já o Ribeirão Piracicamirim, lindeiro à área do bairro, foi retificado e uma de suas margens foi reflorestada, enquanto que a outra não, com o intuito de se viabilizar as obras rotineiras de desassoreamento.

Cabe lembrar que, por não haver uma metodologia única para o cálculo de índices, baseada nos mesmos parâmetros, algumas cidades usam o indice de verde por habitante para exprimir a quantidade de sistema de lazer por munícipe, o que causa a grande discrepância entre índices de quantificação do verde de diferentes municípios.

A avaliação quantitativa apresentada neste item é importante para que, partindo do ponto já estabelecido em outros trabalhos, obtenha-se o índice qualitativo aqui proposto. 
Os dados da Tabela 17 podem dar origem a questionamentos, tais como: quando se trata de espaço livre, deve-se incluir locais de preservação permanente? Até que ponto estes não são locais de acesso à população? E como ficam os casos, como as margens do Rio Piracicaba, já utilizada pela população desde o início da história do município?

Os parâmetros sobre os índices acima expostos podem ser discutidos, mas, como bem colocou Cavalheiro (1996), o índice não deve ser encarado como um valor absoluto e isolado em si mesmo e, sim, como um ponto de reflexão sobre o planejamento do sistema de espaços livres de determinada cidade e como parâmetro de comparação entre urbes, apontando para a avaliação de qualidade ambiental e de vida que se apresentam. Assim, como ocorre em qualquer cidade, também em Piracicaba existem relações muito peculiares com a paisagem. Em um plano de manejo, existem espaços onde a paisagem poderá ser mantida integralmente, assim como áreas que poderão sofrer intervenção, no sentido de propiciar melhor qualidade de vida. Tais propostas podem ser baseadas em conceitos de espaço livre que contenham espaço verde. 


\subsection{Levantamento da cobertura verde}

\subsubsection{Imagem de estudo}

\subsubsection{Fotografia aérea}

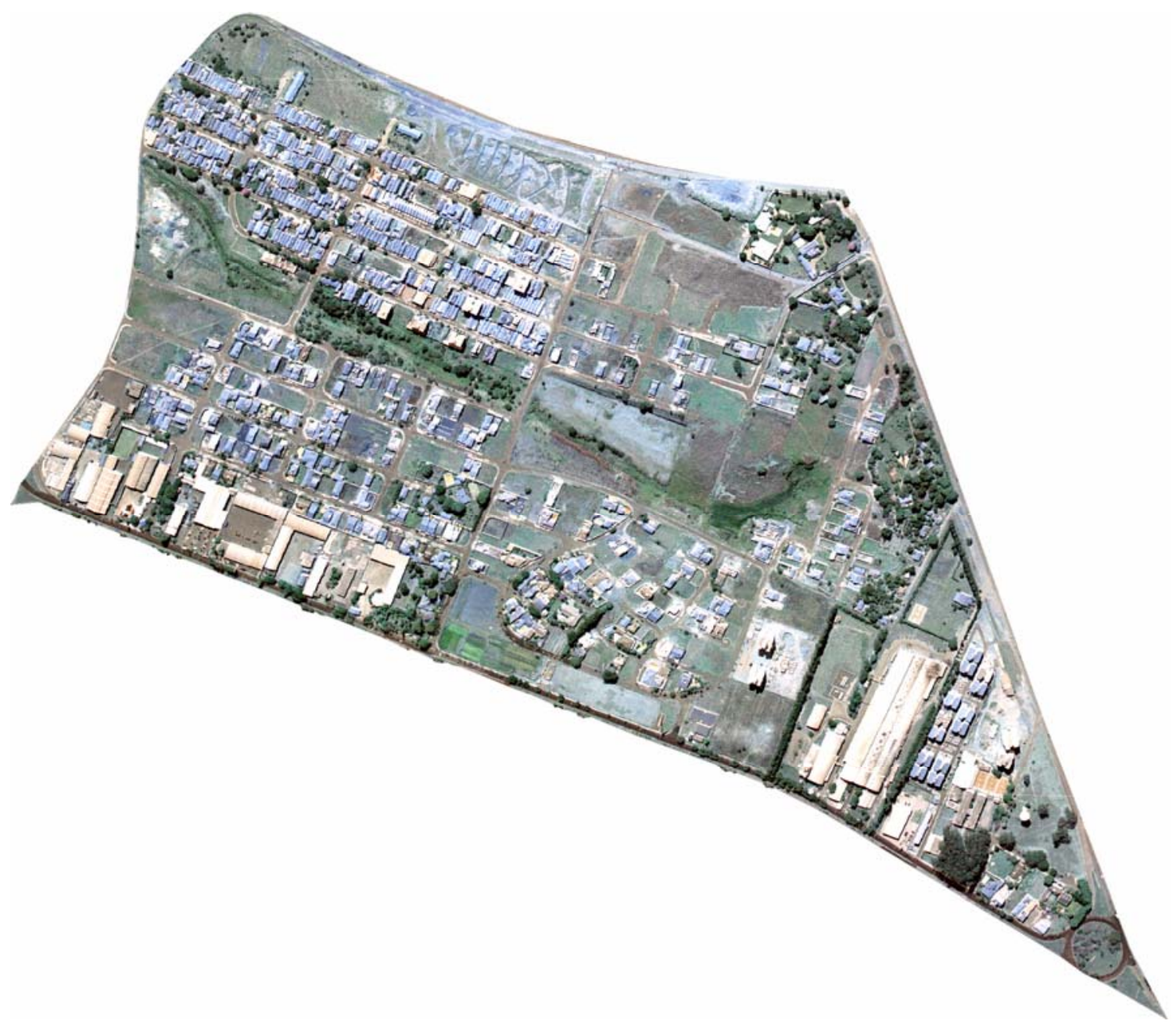

Figura 20 - Fotografia aérea do bairro Santa Cecília, Piracicaba - SP, em 2000 


\subsubsection{Videografia}

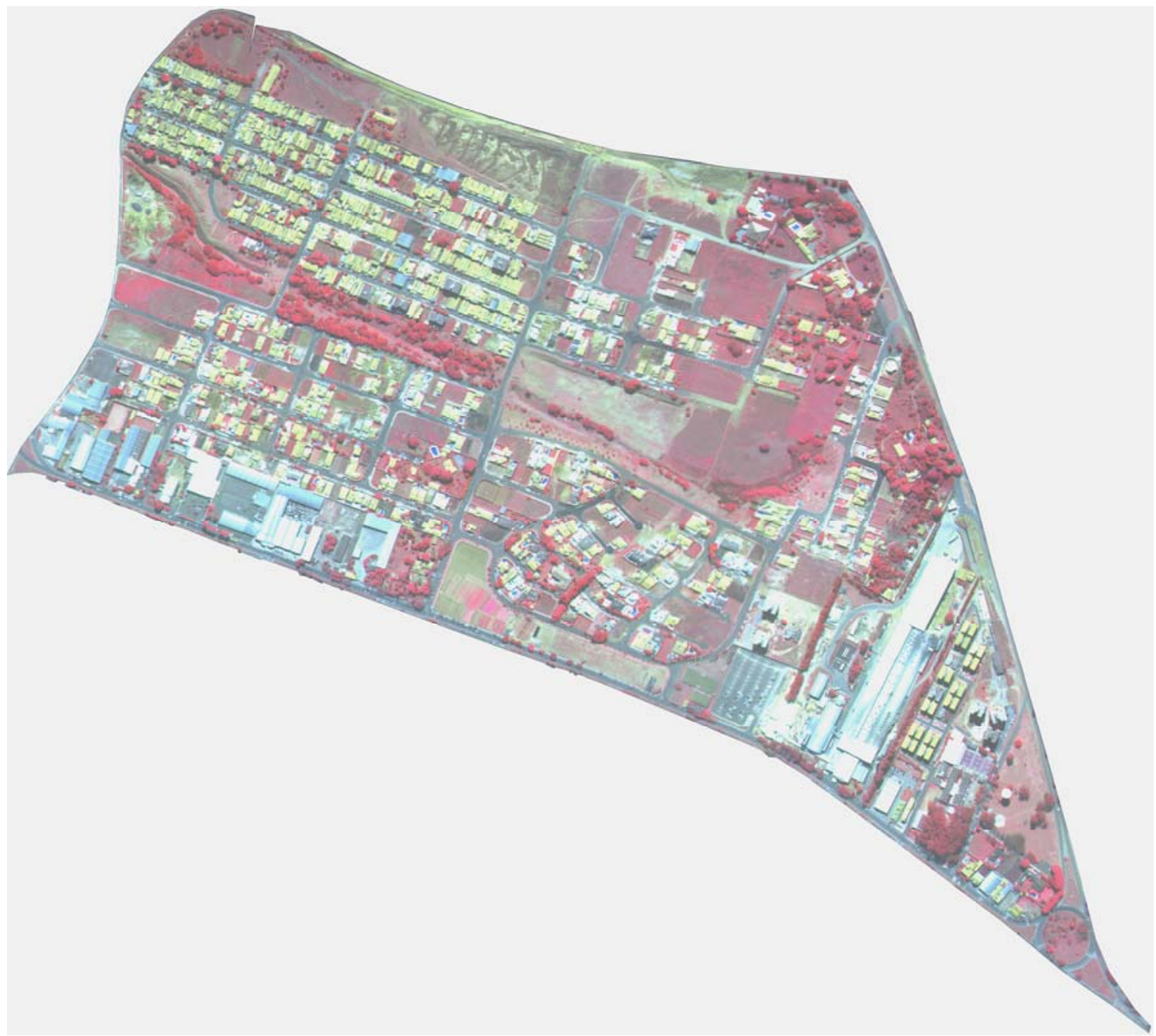

Figura 16 - Videografia do bairro Santa Cecília, Piracicaba - SP, em 2003 


\subsubsection{Classificação das imagens}

A verificação em campo e a confirmação em tela geraram números de subclasses para cada classificação de cobertura de solo, que estão expostos na Tabela 18.

Tabela 18. Números de subclasses por tipo de cobertura do solo do bairro Santa Cecília, Piracicaba - SP

\begin{tabular}{ccc}
\hline & \multicolumn{2}{c}{ Números de subclasses } \\
Cobertura do solo & Fotografia aérea & Videografia \\
\hline Piso impermeável & 10 & 10 \\
Construções & 16 & 15 \\
Solo exposto & 8 & 8 \\
Mato & 6 & 6 \\
Árvore/Arbusto & 10 & 10 \\
Superficie líquida & 1 & 1 \\
Totais & 51 & 50 \\
\hline
\end{tabular}

O número de pontos amostrados definidos pelo cálculo foi de 41 pontos distribuídos na área de estudo, conforme a Figura 22. 


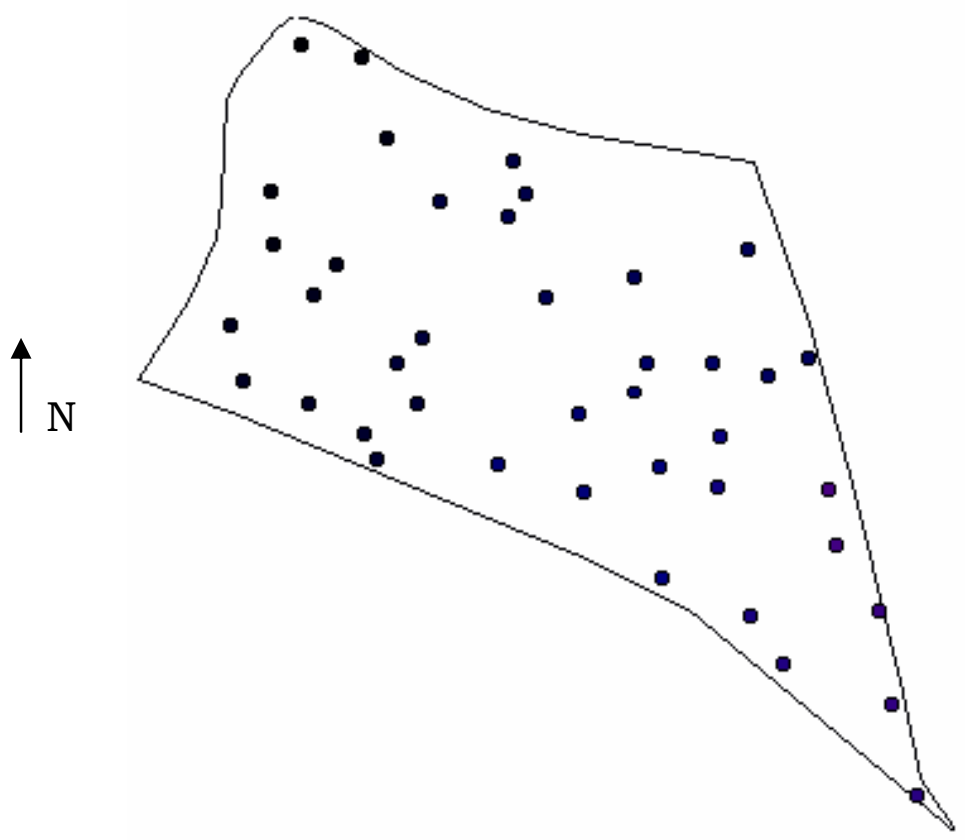

Figura 22 - Distribuição dos pontos amostrais para verificação da exatidão global no bairro Santa Cecília, Piracicaba - SP

\subsubsection{Fotografia aérea}

A classificação do tipo de cobertura do solo por meio do geoprocessamento da fotografia aérea do bairro Santa Cecília é apresentada por área e por proporção, na Tabela 19.

A exatidão global da classificação obtida pela fotografia aérea da área é igual a $88 \%$. 
Tabela 19. Classificação do tipo de cobertura do solo do bairro Santa Cecília, Piracicaba - SP, a partir de fotografia aérea, em 2000

\begin{tabular}{lrr}
\hline Tipo de cobertura do solo & Área $\left(\mathrm{m}^{2}\right)$ & Proporção $(\%)$ \\
\hline Asfalto/Concreto & $308.311,79$ & 25,14 \\
Rua de terra com pedregulho & $49.867,88$ & 4,07 \\
Telhado de residência & $155.139,80$ & 12,65 \\
Telhado de galpão & $62.263,90$ & 5,08 \\
Solo exposto & $135.230,07$ & 11,03 \\
Leito de rio & $62.375,19$ & 5,09 \\
Forração & $226.220,24$ & 18,45 \\
Árvore/Arbusto & $225.801,50$ & 18,41 \\
Superfície líquida & $1.096,24$ & 0,09 \\
\multicolumn{1}{c}{ Totais } & & \\
Ambiente construído & $525.715,49$ & 42,87 \\
Solo exposto & $247.473,14$ & 20,18 \\
Forração & $226.220,24$ & 18,45 \\
Cobertura arbórea & $225.801,50$ & 18,41 \\
Superficie líquida & $1.096,24$ & 0,09 \\
\hline
\end{tabular}




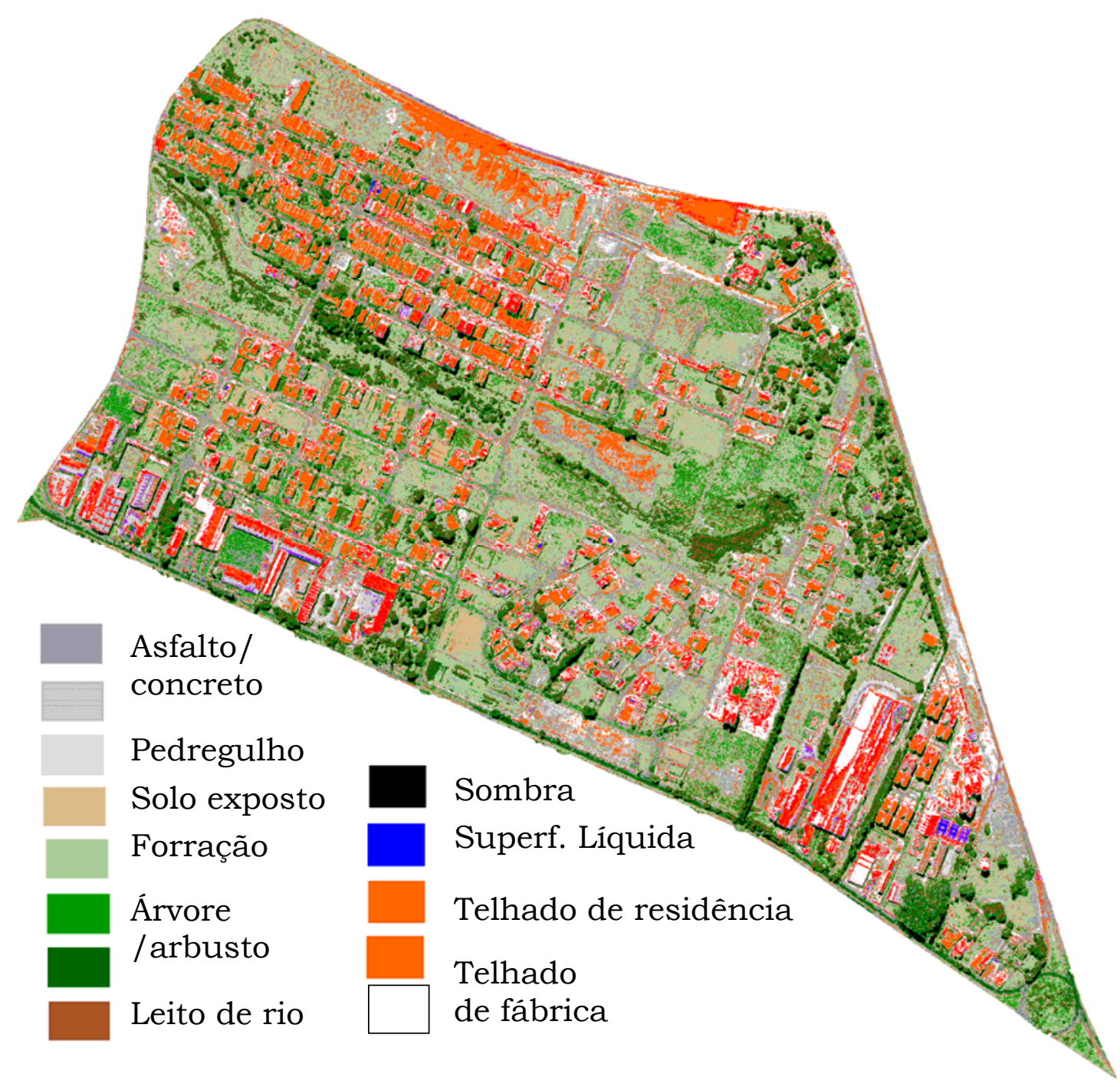

Figura 23 - Modelo digital do bairro Santa Cecília, Piracicaba - SP, baseado em fotografia aérea de 2000 


\subsubsection{Videografia}

A classificação do tipo de cobertura do solo por meio do geoprocessamento da videografia do bairro Santa Cecília é apresentada por área e por proporção, na Tabela 20.

A exatidão global da classificação obtida pela videografia da área é igual a $93 \%$.

Tabela 20. Classificação do tipo de cobertura do solo do bairro Santa Cecília, Piracicaba - SP, a partir de videografia, em 2003

\begin{tabular}{lrc}
\hline Tipo de cobertura do solo & Área $\left(\mathrm{m}^{2}\right)$ & Proporção $(\%)$ \\
\hline Asfalto/Concreto & $353.463,15$ & 29,61 \\
Rua de terra com pedregulho & $56.305,44$ & 4,72 \\
Telhado de residência & $224.811,72$ & 18,83 \\
Telhado de galpão & $129.999,16$ & 10,89 \\
Solo exposto & $80.069,06$ & 6,71 \\
Leito de rio & $39.969,68$ & 3,35 \\
Forração & $110.778,67$ & 9,28 \\
Cobertura arbórea & $196.724,00$ & 16,48 \\
Superfície líquida & $1.547,02$ & 0,13 \\
\multicolumn{1}{c}{ Totais } & & \\
Ambiente construído & $708.274,03$ & 59,34 \\
Solo exposto & $176.344,17$ & 14,77 \\
Forração & $110.778,67$ & 9,28 \\
Cobertura arbórea & $196.724,00$ & 16,48 \\
Superficie líquida & $1.547,02$ & 0,13 \\
\hline
\end{tabular}




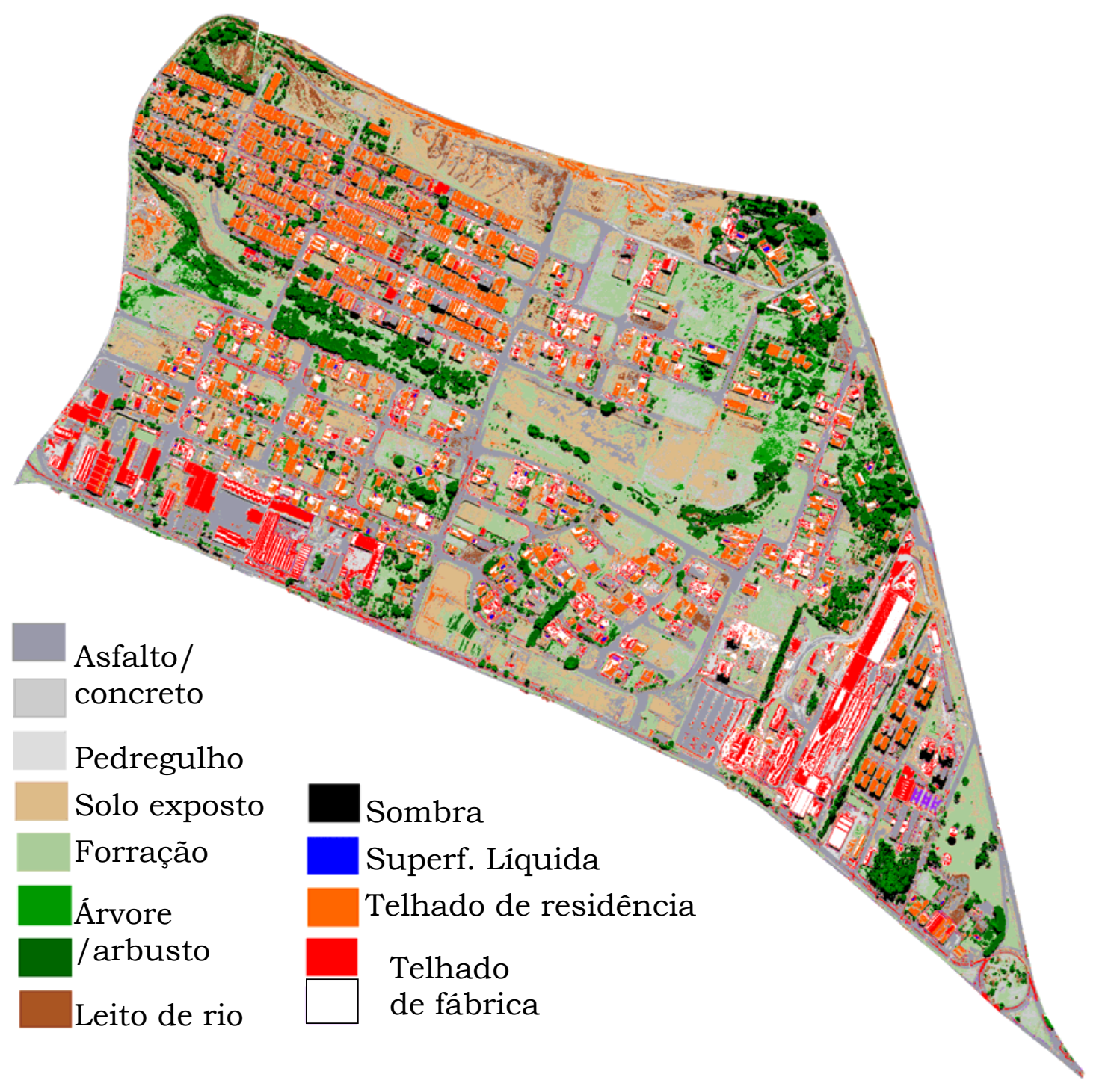

Figura 24 - Modelo digital do bairro Santa Cecília, Piracicaba - SP, baseado em videografia de 2003 


\subsubsection{Cálculo do Índice de Cobertura Vegetal em Áreas Urbanas (ICVAU) e do Índice de Verde por Habitante (IVH)}

Para calcularmos o ICVAU, podemos obter a "proporção de manchas verdes" de duas formas: a primeira é optar-se por ser essa proporção "as manchas de vegetação visíveis a olho nu" (Nucci \& Cavalheiro, 1996) e extrapolar-se para o que se extrai de "verde" de fotografia aérea ou de videografia (forração + cobertura arbórea), por meio do geoprocessamento (Tipo 1); a segunda possibilidade é considerar como "proporção de manchas verdes" apenas "as vegetações de porte arbóreo e arbustivo visiveis a olho nu" e extrapolar-se para o que se extrai desse tipo de mancha verde de fotografia aérea ou de videografia, por meio do geoprocessamento (Tipo 2). Portanto, optou-se por expressar os dados obtidos por esses cálculos na Tabela 21.

Tabela 21. Índice de Cobertura Vegetal em Área Urbana (ICVAU) e Índice de Verde por Habitante (IVH) do bairro Santa Cecília, Piracicaba -SP

Tipo de mancha verde

$$
\text { ICVAU (\%) }
$$

Fotografia aérea Videografia

Forração + Cobertura arbórea

Cobertura arbórea

Forração + Cobertura arbórea
Cobertura arbórea

$$
36,86
$$$$
18,41
$$$$
\text { IVH }\left(\mathrm{m}^{2} / \mathrm{hab}\right)
$$

Fotografia aérea Videografia 234,09 101,96 116,93 65,21 
O ICVAU e o IVH mostraram que essa é uma área com um razoável porcentual de verde, ICVAU $=18,41 \%$ (fotografia aérea) e 16,48\% (videografia) e $I V H=116,93 \mathrm{~m}^{2} /$ hab (fotografia aérea) e $65,21 \mathrm{~m}^{2} / \mathrm{hab}$ (videografia). Como não é populosa, o IVH é bem alto, se comparado ao Setor N-5 da cidade de Ribeirão Preto (Guzzo, 1999), que apresentou um ICVAU de 6,7\% (pelo programa Auto-Cad) e um IVH de 12,96 $\mathrm{m}^{2} / \mathrm{hab}$. A comparação é feita com o subsetor N-5 daquele trabalho, porque é a área mais parecida com a que foi aqui estudada. Cabe lembrar que, tanto a proporção de áreas com cobertura arbórea, como a proporção de áreas com forração incluem as áreas particulares; muitas delas são terrenos sem construção. Em alguns casos, os terrenos não só possuem mato, mas também solo exposto, o que não entrou no percentual de áreas com forração.

As diferenças entre os números da fotografia aérea e os da videografia, tanto podem ser decorrentes de variações dos geoprocessamentos que interpretam as cores de formas diferentes, como podem ser devidas às variações entre os anos em que foram feitas a fotografia aérea, 2000, e a videografia, 2003. Entre esses anos, vários terrenos vazios foram ocupados com construções. Esse fato pode ser percebido analisando-se os dados contidos nas Tabelas 18 e 19: a área construída aumentou $16,47 \%$. Nos tipos de cobertura "telhado de residência" e "telhado de galpão", o aumento foi de 11,99\%, o que significa uma grande participação no aumento global de ambiente construído. Pela exatidão global, avaliou-se que as diferenças entre as classificações feitas pelo geoprocessamento da fotografia aérea (88\%)e o da videografia (93\%) são mínimas, o que não compromete a avaliação temporal aqui realizada. Além do mais, fica claro que se pode utilizar com segurança a videografia, com as vantagens dela ter menor custo 
que a fotografia aérea, além de fornecer uma disponibilidade instantânea dos dados.

A avaliação do percentual dos tipos de cobertura verde mostra que houve diminuição da área com cobertura arbórea e com forração. Como não houve alterações na área de espaços livres públicos durante o período entre a realização da fotografia aérea e a da videografia, esse fato pode ser atribuído a modificações da vegetação em áreas particulares e na arborização viária. Os dados presentes no item 4.1 mostraram que o número de árvores/km aumentou, de 2001 para 2003, de 38,75 (Tabela 5) para 39,80 (Tabela 7). Contudo, houve uma discreta diminuição do diâmetro médio de copa de árvores de 2001 para 2003; a maior classe de diâmetro com $14 \%$ e a menor classe com 54\%, modificando para $13 \%$ e $57 \%$, respectivamente (item 4.2 - Figura 11). Supondo-se que se multiplicasse o valor de arv $/ \mathrm{km}$ pelo porcentual de cada classe de diâmetro médio, encontrar-se-ia os seguintes valores: em 2001, para a maior classe de diâmetro, 5,42 arv/ $\mathrm{km}$ e para a menor, 20,92 arv/ km. Em 2003, para a maior classe de diâmetro, o valor seria $5,17 \mathrm{arv} / \mathrm{km}$ e para a menor classe, $22,69 \mathrm{arv} / \mathrm{km}$.

Dos $25,76 \%$ de cobertura verde total (forração + cobertura arbórea), em 2003, sabe-se que 1,35\% é de verde de acompanhamento viário (item 4.2 - Tabela 13), lembrando que o PELUP é de10,52\% (item 4.3 - Tabela 16), mas não se pode precisar o quanto da cobertura arbórea e forração pertence aos espaços livres de uso público e às áreas particulares (residências, comércio, indústria e terrenos). Além disso, para se ter uma idéia de qual é a contribuição total da arborização viária, necessita-se saber o quanto há de arborização de calçadas. Assim, por meio do levantamento de campo, estima-se a arborização de calçadas e, por meio de levantamento remoto, estima-se todo o sistema viário, comparando-se os dois métodos. 
O cálculo da copa de árvore por meio do levantamento de campo é feito a partir dos dados de classe de diâmetro (exposto no item 4.2 Fig. 11). Assume-se uma copa circular e com os dois diâmetros iguais. O cálculo da superfície de copa é feito por:

$$
\begin{aligned}
& \mathrm{S}_{\mathrm{c}}=\pi(\mathrm{D} / 2)^{2} \\
& \mathrm{D}=\text { diâmetro médio de copa de árvore. }
\end{aligned}
$$

A partir desse cálculo, multiplica-se a superficie de copa pelo número total de árvores levantadas (item 4.1 - Tabela 7), para se chegar ao total de área de cobertura arbórea (árvores/arbustos).

O cálculo da copa de árvore, por meio das imagens obtidas pela fotogrametria aérea e pela videografia, foi realizado a partir de um corte na imagem que possibilitou retirar as árvores de todo sistema viário e calcular a cobertura arbórea não-viária.

Para se calcular a cobertura arbórea viária subtraiu-se do total de cobertura arbórea a cobertura arbórea não-viária. Os dados comparativos são apresentados na Tabela 22.

Observando-se a Tabela 22, percebe-se que o levantamento em campo foi mais semelhante à videografia de 2003 que à fotografia aérea de 2000. Apesar de a fotografia aérea ser de 2000 e de o levantamento em campo, de 2001, as alterações de arborização de calçadas não poderiam ter sido tão drásticas, de 2000 para 2001, reduzindo o valor em 5,7 vezes, uma vez que a cobertura arbórea total da área reduziu-se em 1,93\%. A diferença deve-se, provavelmente, à falta de nitidez da fotografia aérea, que não permitiu uma boa seleção no momento do corte, não possibilitando separar corretamente o que são árvores de 
calçadas do resto, como bem realizado na videografia, na qual o infravermelho permitiu que as árvores fossem melhor destacadas.

Tabela 22. Área e porcentual de cobertura arbórea de calçadas do bairro Santa Cecília, Piracicaba - SP, por meio de levantamento em campo, fotografia aérea e videografia

\begin{tabular}{cccc}
\hline $\begin{array}{c}\text { Cobertura arbórea de } \\
\text { calçadas }\end{array}$ & 2000 & 2001 & 2003 \\
\hline $\begin{array}{c}\text { Levantamento em campo } \\
\text { Fotografia aérea } \\
\text { Videografia }\end{array}$ & - & $9.440,49$ & $9.329,18$ \\
& $68.523,42$ & & $13.071,99$ \\
Levantamento em campo & - & $(\%)$ & 0,76 \\
Fotografia aérea & - & 0,77 & - \\
Videografia & -17 & - & 1,10 \\
\hline
\end{tabular}

O porcentual de árvores de calçada $(1,10 \%)$ é menor, quando se comparam os valores com aquelas cidades onde já foram realizados levantamentos semelhantes (Maco \& McPherson, 2002). 


\section{5 Índice de Qualidade do Espaço Verde Urbano com Função Ecológica (IQEVUe)}

O Índice de Qualidade do Espaço Verde Urbano com Função Ecológica é um valor numérico que expressa a qualidade da vegetação em propiciar benefícios à unidade de paisagem à qual ela pertence.

\subsubsection{Obtenção do IQEVUe}

\subsubsection{Fórmula do IQEVUe}

A fórmula do IQEVUe é:

$$
\mathrm{IQEVU}_{\mathrm{e}}=\mathrm{S}+\mathrm{H}+\mathrm{C}+\mathrm{T}
$$

$\mathrm{S}=$ sombreamento total de árvores de calçada;

$\mathrm{H}=$ hidrologia da área total;

$\mathrm{C}$ = fixação de Carbono da área total;

$\mathrm{T}=$ atuação da temperatura na área total.

A seguir, serão explicados o significado de cada componente, conforme estudo da bibliografia existente sobre o assunto, a dedução da fórmula e como cada componente foi calculado. 


\subsubsection{Sombreamento total de árvores de calçada}

Para a elaboração do IQEVUe, considera-se somente o sombreamento propiciado por árvores de calçada, uma vez que a influência delas sobre o ambiente construído é direta, provocando maior efeito de conforto térmico do que árvores situadas em locais distantes das construções (Grimmond et al., 1986; Bajwa, 1995).

A fórmula do sombreamento total de árvores de calçada é:

$$
\mathrm{S}=\overline{\mathrm{S}} \times \mathrm{R}
$$

$\mathrm{S}$ = sombreamento total de árvores de calçada;

$\overline{\mathrm{S}}=$ sombreamento médio das árvores de calçada $\left(\mathrm{m}^{2} / \mathrm{m}\right)$;

$\mathrm{R}=$ número total de árvores de calçada $/ \mathrm{m}$ linear de calçada $(1 / \mathrm{m})$

O sombreamento total de árvores de calçadas (S) é definido, primeiramente, pelo sombreamento médio $(\overline{\mathrm{S}})$, multiplicado pelo número de árvores de calçada/m (R). Esta operação é feita para que se considere o sombreamento por metro linear de calçada. Em seguida, ao multiplicar-se esse valor obtido pelo porcentual de cobertura arbórea de calçada, obtém-se um número que é proporcional ao total de sombreamento fornecido pela cobertura arbórea das calçadas.

O sombreamento médio é obtido por:

$$
\begin{aligned}
& \overline{\mathrm{S}}=\mathrm{S}_{1}+\mathrm{S}_{2}, \text { sendo: } \\
& \mathrm{S}_{1}=\text { dimensão do sombreamento }(\mathrm{m}) ; \\
& \mathrm{S}_{2}=\text { tipo de sombreamento. }
\end{aligned}
$$


O sombreamento médio depende da dimensão de cada árvore. Como cada espécie de árvore possui um tipo de sombreamento, a depender de sua arquitetura foliar, que vai permitir maior ou menor passagem dos raios do sol, é preciso considerar essa contribuição.

A dimensão do sombreamento $\left(\mathrm{S}_{1}\right)$ foi definida a partir das observações realizadas nesse trabalho, no item 4.2, sobre os aspectos morfológicos das árvores - classes de altura e diâmetro de copa -, que podem fornecer muitas informações sobre a realidade da árvore, desde a relação da copa com a altura, até uma análise de presença ou não de poda de um ano para outro. Existem muitas outras possibilidades de se expressar quanto uma árvore está sombreando, desde utilizar medidas de incidência de radiação (Sattler et al., 1987; Canton et al., 1994; Silva et al., 1996), até relacionar o sombreamento das copas de árvores com a economia de energia (Mcpherson \& Simpson, 1996; Simpson, 1998).

Para chegar-se a uma fórmula que determine a dimensão do sombreamento, é necessário que o valor desse parâmetro represente a realidade e contenha uma lógica matemática. A princípio, poder-se-ia considerar apenas o produto da altura pelo diâmetro para representar a projeção da copa como forma de medir o sombreamento, pois este produto é proporcional ao cone de sombra propiciado pela árvore. Porém, caso se aumente somente um dos fatores, a realidade de campo poderá ser mascarada. Por exemplo, para uma palmeira jerivá (Syagrus romanzoffiana), com $8 \mathrm{~m}$ de altura e $3 \mathrm{~m}$ de diâmetro de copa, o produto seria igual a $24 \mathrm{~m}$; por outro lado, para uma sibipiruna (Caesalpinia peltophoroides), com $6 \mathrm{~m}$ de altura e $4 \mathrm{~m}$ de diâmetro de copa, o produto seria o mesmo, $24 \mathrm{~m}$. Entretanto, sabe-se que, pela quantidade de folhas e por sua arquitetura, o sombreamento dessa sibipiruna é maior que daquela palmeira. Dessa forma, é preciso encontrar uma solução para 
representar esse benefício, que continue utilizando o mínimo possível de fatores.

Feitos vários processos empíricos de análise dos dados levantados nesse trabalho, avaliaram-se várias formas de obter-se a dimensão do sombreamento, mantendo o uso de altura e de diâmetro como parâmetros representativos, resultando na seguinte fórmula:

$$
\begin{aligned}
& \mathrm{S}_{1}=\frac{\mathrm{A} \times \mathrm{D}}{\mathrm{A}+\mathrm{D}} \\
& \mathrm{A}=\text { altura média das árvores de calçada }(\mathrm{m}) ; \\
& \mathrm{D}=\text { Diâmetro médio das copas das árvores de calçada }(\mathrm{m}) .
\end{aligned}
$$

Para provar que a fórmula acima é válida, isto é, que a área do sombreamento médio cresce à medida que, juntos, a altura e o diâmetro são maiores, não bastando aumentar somente um desses parâmetros, fez-se as seguintes derivações:

$$
\frac{A \times D}{A+D}=\frac{1}{\frac{1}{D}+\frac{1}{A}} \quad \therefore \quad \lim _{\substack{A \rightarrow \infty \\ D \rightarrow \infty}}=\frac{A \times D}{A+D}=\lim _{\substack{A \rightarrow \infty \\ D \rightarrow \infty}}=\frac{1}{\frac{1}{D}+\frac{1}{A}}=\infty
$$

Fica assim demonstrado que, quanto maiores o diâmetro da copa e a altura da árvore, maior será a dimensão de seu sombreamento. Esse componente do sombreamento $\left(\mathrm{S}_{1}\right)$ foi testado para as diferentes classes de diâmetro de copa arbórea e altura de árvores, obtidas no levantamento qualitativo de 2.003 e expostas no item 4.2. O resultado dessa análise é apresentado na Figura 25. 


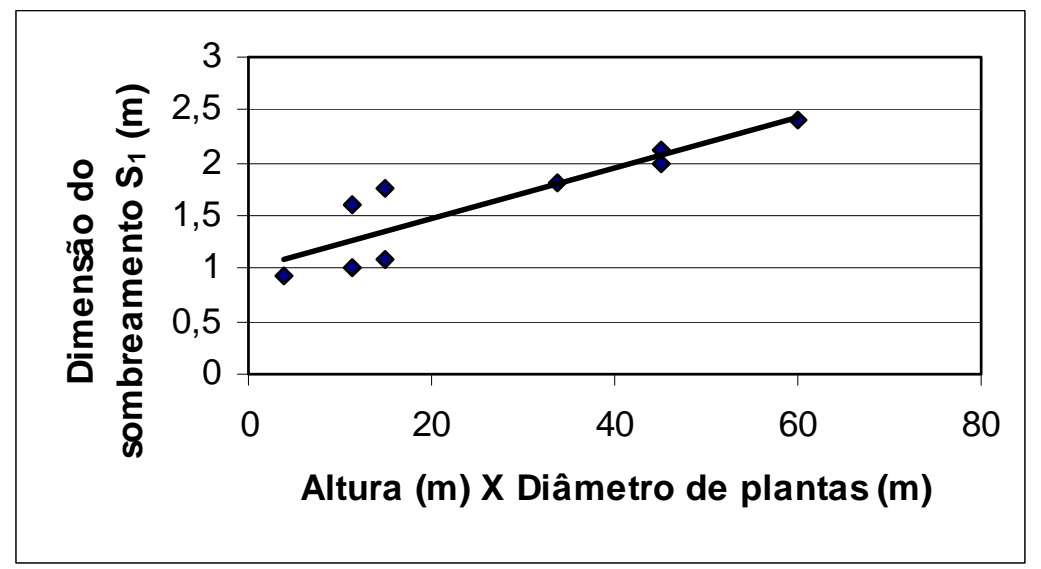

Figura 25 - Relação entre dimensão de sombreamento $\left(\mathrm{S}_{1}\right)$ e o produto da altura pelo diâmetro de copa das árvores de calçada do bairro Santa Cecília, Piracicaba - SP

Neste trabalho, o sombreamento médio de calçadas é calculado a partir da dimensão e do tipo de sombreamento. Apesar de alguns trabalhos, como os de Canton et al. (1994) e Bueno (1998), medirem o sombreamento por espécie, tendo em vista que cada espécie provoca um tipo de sombreamento, não é possível calcular o valor exato para cada espécie arbórea ou arbustiva dentro do inventário, quando se pretende criar um índice que represente o sombreamento de forma geral. Tal fato levanta a dúvida de como representar uma diferença que deve ser mostrada. Caso se considere apenas a quantidade de sombreamento, isto poderia representar que áreas que possuem um mesmo valor de copa média e um mesmo número de indivíduos, mas com espécies diferentes, teriam um mesmo sombreamento, o que não é verdade. Portanto, é preciso encontrar-se uma solução que mais se aproxime da realidade.

Os componentes do IQEVUe devem demonstrar qualidade e não quantidade. Por isso, optou-se por expor, de alguma forma, a 
possibilidade de diferentes espécies propiciarem diferentes tipos de sombreamento. A melhor maneira de representar numericamente essas diferenças é basear-se na "teoria da informação", citada por Peet (1975), ou seja, cada indivíduo (espécie) tem um tipo de sombreamento $\left(\mathrm{S}_{2}\right)$, o que leva ao uso do Índice de Diversidade de Shannon (IDS), daí sua participação no cálculo do sombreamento médio das árvores de calçada $(\overline{\mathrm{S}})$ :

$\mathrm{S}_{2}=$ IDS

Por sua vez,

IDS $=-\Sigma \rho_{\mathrm{i}} \cdot \ln \cdot \rho_{\mathrm{i}}, \quad$ sendo $\rho_{\mathrm{i}} \quad \mathrm{o}$ porcentual de número de indivíduos da espécie em relação ao número total de indivíduos.

\subsubsection{Hidrologia da área total}

Whitford (2001) utilizou dados de precipitação, de tipo de solo e de tipo de cobertura para calcular o escoamento superficial, como indicativo de hidrologia. Como aqui não se pretende quantificar o escoamento superficial e, sim, qualificar os beneficios do verde em promover a infiltração ou evitar erosão, na área urbana, apenas se utiliza, como parâmetro, o tipo de cobertura de solo urbano.

A hidrologia da área em estudo, como componente do IQEVUe, precisa ser representada de forma a incluir a contribuição do verde nas cidades, por diminuir o escoamento superficial de chuvas, que aumenta com a impermeabilização. Isso será representado de forma simplificada, pelas variações de permeabilidade do solo. 
A avaliação da permeabilidade do solo, neste trabalho, usa os efeitos de tipos de cobertura que permitem menor ou maior passagem de água, seja interceptando, como cobertura arbórea, seja permitindo que haja infiltração no solo. Considera-se impermeável um terreno onde não ocorre nenhuma infiltração de água. Para locais com pavimentos, como calçadas de ruas ou praças, quanto maior for a proporção de áreas sem pavimento, com algum tipo de forração, maior será a permeabilidade, sendo esta condição aqui denominada "calçada verde" ou "calçada ecológica”. Para a arborização em todos espaços verdes, considerou-se que a cobertura arbórea intercepta parte da água de chuva e o restante é armazenado no solo ou faz parte do escoamento superficial. Portanto, a cobertura arbórea deve ser um item a considerar, com relação às condições de hidrologia do local. Então, a fórmula para representar a hidrologia é:

$H=\frac{\rho A P_{T}}{\rho A I_{T}} \times \rho C A$, sendo:

$\mathrm{H}=$ hidrologia da área total;

$\rho \mathrm{AP}_{\mathrm{T}}=$ porcentual de área permeável total;

$\rho A I_{T}=$ porcentual de área impermeável total;

$\rho \mathrm{CA}=$ porcentual de cobertura arbórea.

Por sua vez, tem-se:

$\rho \mathrm{AP}_{\mathrm{T}}=\rho \mathrm{AP}_{\mathrm{SE}}+\rho \mathrm{AP}_{\mathrm{F}}+\rho \mathrm{AP}_{\mathrm{CA}}+\rho \mathrm{AP}_{\mathrm{SL}}$

Ou seja: 
$\rho \mathrm{AP}_{\mathrm{SE}}=$ porcentual de área permeável com solo exposto;

$\rho \mathrm{AP}_{\mathrm{F}}=$ porcentual de área permeável com forração;

$\rho \mathrm{AP}_{\mathrm{CA}}=$ porcentual de área permeável com cobertura arbórea;

$\rho \mathrm{AP}_{\mathrm{SL}}=$ porcentual de área permeável com superficie líquida.

Por sua vez, o porcentual de área impermeável total é dado por:

$\rho A \mathrm{IT}_{\mathrm{T}}=\rho \mathrm{AI}-\rho \mathrm{APP}$

$\rho \mathrm{AI}_{\mathrm{I}}=$ porcentual de área impermeável total obtida na imagem;

$\rho \mathrm{AP}_{\mathrm{P}}=$ porcentual de área permeável, em local com área pavimentada, em relação a área total.

$\mathrm{O} \rho \mathrm{AP}_{\mathrm{P}}$ é calculado a partir de áreas permeáveis, em locais onde predominam áreas pavimentadas.

\subsubsection{Fixação de Carbono da área total}

A contribuição da vegetação urbana para a purificação do ar e para a diminuição do efeito estufa é principalmente devida à retirada de Carbono do ambiente. Essa retirada pode ser medida por quanto de Carbono é absorvido e quanto de Carbono é fixado. Aqui, opta-se por avaliar somente a possibilidade de fixação de Carbono, uma vez que isso já demonstra o balanço entre o que foi retirado e o que ficou na planta.

A fixação de Carbono, em uma dada área, é realizada por toda a vegetação presente, conforme Withford (2001). Porém, pode-se considerar que a porcentagem da cobertura arbórea representa o local onde há a maior parte do estoque de Carbono (Jo, 2002). Como se pretende obter a qualidade da vegetação urbana em relação à possibilidade de realizar fixação de Carbono não a quantidade 
efetivamente fixada, adaptou-se a fórmula usada por Withford (2001), para representar a fixação de Carbono:

$$
\begin{aligned}
& C=\rho A C A, \text { sendo } \\
& C \text { = fixação de carbono; } \\
& \rho A C A=\text { porcentual de área com cobertura arbórea. }
\end{aligned}
$$

\subsubsection{Atuação da temperatura na área total}

Os métodos de avaliar-se a atuação da vegetação sobre a área urbana são complicados no que se refere à temperatura, pois não correlacionam diretamente o tipo de cobertura de solo com sua influência sobre a temperatura. Isso se deve ao fato de os valores de temperatura expressarem um misto de vários eventos, como vento, evaporação, convecção, advecção, que não podem ser relacionados de forma simples com a cobertura do solo (Voogt \& Oke, 2003).

Em países tropicais, o principal efeito da vegetação é amenizar ou arrefecer os efeitos indesejados das altas temperaturas, o que se faz mais necessário nos meses de verão.

Reiterada a importância da necessidade de medir-se a diminuição dos efeitos das ilhas de calor urbanas por ação da vegetação, em locais tropicais, é preciso agora avaliá-la numericamente, de forma a levar em consideração outros fatores que não apenas a proporção de cada tipo de cobertura do solo.

Estudos de climatologia urbana mostraram que temperatura de superficie é um dos fatores mais adequados para se avaliar a influência da cobertura do solo sobre a temperatura (Lombardo, 1985; Roth et al., 1989; Asaeda \& Ca, 1993; Nichol, 1994; Kjelgren \& Montague, 1998; 
Arnfield, 2000; Bias et al., 2003; Voogt \& Oke, 2003). Todavia, é necessário comparar a temperatura de superficie com a temperatura do ar, porque esta última sintetiza o efeito de vários outros fatores que atuam no estado térmico de uma área. Nichol (1994) observou que, embora não haja uma relação direta entre os dados de temperatura de superficie e os de temperatura do ar, eles possuem uma alta correlação entre si, durante o dia. Portanto, as temperaturas de superficie, obtidas pelo satélite, durante o dia, são válidas para compor um índice que retrate os efeitos das camadas de cobertura do solo sobre a capacidade de atenuação da temperatura de uma dada área, apesar de todos os efeitos noturnos das ilhas de calor.

O componente climático que reflete os efeitos do espaço verde urbano sobre a temperatura, expresso pelo IQEVUe, aqui chamado "atuação da temperatura" (T), é calculado pela fórmula abaixo:

$$
\begin{aligned}
& \mathrm{T}=\operatorname{Tr} \times \rho \mathrm{Ar}, \text { sendo: } \\
& \mathrm{T} \text { = atuação da temperatura; } \\
& \mathrm{Tr}=\text { temperatura de resfriamento; } \\
& \rho \mathrm{Ar}=\text { porcentual de ambiente resfriado. }
\end{aligned}
$$

Por sua vez, a temperatura de resfriamento é obtida da seguinte forma:

$$
\operatorname{Tr}=\frac{\mathrm{TA}}{\mathrm{TS}}
$$

$\mathrm{TA}=$ temperatura média do ar da área total $\left({ }^{\circ} \mathrm{C}\right)$.

$\mathrm{TS}=$ temperatura de superficie total $\left({ }^{\circ} \mathrm{C}\right) ;$ 
A temperatura de superficie total é a somatória das proporções de cada classe de temperatura de superfície, sendo definida, cada uma dessas proporções, pela multiplicação da temperatura de superficie captada pelo satélite $\left(\mathrm{TS}_{\mathrm{i}}\right)$ pelo porcentual em que ela ocorre $\left(\rho_{\mathrm{i}}\right)$, na área total. Assim:

$\mathrm{TS}=\left(\mathrm{TS}_{1} \times \rho_{1}\right)+\left(\mathrm{TS}_{2} \times \rho_{2}\right)+\ldots+\left(\mathrm{TS}_{\mathrm{n}} \times \rho_{\mathrm{n}}\right)$

$\mathrm{TS}_{\mathrm{i}}=$ temperatura de superficie $\mathrm{i}\left({ }^{\circ} \mathrm{C}\right)$, na área $\mathrm{i}$.

$\rho_{\mathrm{i}}=$ porcentual de ocorrência da temperatura de superfície (Tsi), na área total.

O porcentual de ambiente resfriado( $\rho$ Ar) é dado por:

$\rho A r=\frac{\rho A C A+\rho A f+\rho A S L}{\rho A A C+\rho A S E}$, onde:

$\rho A_{C A}=$ porcentual de área com cobertura arbórea;

$\rho A F=$ porcentual de área com forração;

$\rho A s L=$ porcentual de área com superfície líquida;

$\rho \mathrm{A}_{\mathrm{AC}}=$ porcentual de área com ambiente construído;

$\rho A_{S E}=$ porcentual de área com solo exposto. 


\subsubsection{Cálculo do IQEVUe}

Para demonstrar como o índice pode ser obtido a partir de dados reais, o cálculo do IQEVUe foi feito com base nos dados levantados no bairro Santa Cecília, Piracicaba - SP, apresentados anteriormente, neste trabalho.

\subsubsection{Sombreamento total das árvores de calçada do bairro Santa Cecilia, Piracicaba - SP}

Para o cálculo do sombreamento total de árvores de calçada do bairro Santa Cecília, utilizaram-se os dados da amostragem aleatória simples, em consonância com as afirmações feitas no item 4.1.

Tabela 23. Parâmetros avaliados para o cálculo do sombreamento total das árvores de calçadas do bairro Santa Cecília, Piracicaba - SP

\begin{tabular}{cc}
\hline Parâmetro das árvores de calçada & 2003 \\
\hline Altura média $(\mathrm{A})(\mathrm{m})$ & 4,5240 \\
Diâmetro médio $(\mathrm{D})(\mathrm{m})$ & 2,9905 \\
Dimensão do sombreamento $\left(\mathrm{S}_{1}\right)\left(\mathrm{m}^{2} / \mathrm{m}\right)$ & 1,8004 \\
Tipo de sombreamento $\left(\mathrm{S}_{2}\right)$ & 3,0660 \\
Sombreamento médio $(\overline{\mathrm{S}}) \mathrm{S}_{1}+\mathrm{S}_{2}\left(\mathrm{~m}^{2} / \mathrm{m}\right)$ & 4,8664 \\
Árvore $/$ metro $(\mathrm{R})(1 / \mathrm{m})$ & 0,0396 \\
SOMBREAMENTO TOTAL DAS ÁRVORES & 0,1929 \\
DE CALÇADA $(\mathrm{S}=\overline{\mathrm{S}} \times \mathrm{R})$ & \\
\hline
\end{tabular}


4.5.2.2 Hidrologia total do bairro Santa Cecilia, Piracicaba - SP

A Tabela 24 expressa os dados de hidrologia do bairro Santa Cecília, a partir dos parâmetros levantados na videografia.

Tabela 24. Parâmetros avaliados para o cálculo da hidrologia total do bairro Santa Cecília, Piracicaba - SP

\begin{tabular}{|c|c|}
\hline Parâmetro da Hidrologia & Videografia \\
\hline Área permeável com solo exposto ( $\left.\rho \mathrm{AP}_{\mathrm{SE}}\right)$ & 0,1477 \\
\hline Área permeável com forração ( $\left.\rho \mathrm{AP}_{\mathrm{F}}\right)$ & 0,0928 \\
\hline Área permeável com cobertura arbórea ( $\left.\rho \mathrm{AP}_{\mathrm{CA}}\right)$ & 0,1648 \\
\hline Área permeável com superficie líquida ( $\left.\rho \mathrm{AP}_{\mathrm{SL}}\right)$ & 0,0013 \\
\hline Área permeável total $\left(\rho \mathrm{AP}_{\mathrm{T}}\right)$ & 0,4066 \\
\hline Área impermeável total obtida na imagem $\left(\rho \mathrm{AI}_{\mathrm{I}}\right)$ & 0,5934 \\
\hline $\begin{array}{c}\text { Área permeável em local com área pavimentada } \\
\text { em relação a área total }\left(\rho \mathrm{AP}_{\mathrm{P}}\right)\end{array}$ & 0,0009 \\
\hline Área impermeável total $\left(\rho \mathrm{AI}_{\mathrm{T}}\right)$ & 0,5925 \\
\hline Área de cobertura arbórea $(\rho \mathrm{CA})$ & 0,1648 \\
\hline \multicolumn{2}{|l|}{ HIDROLOGIA DO BAIRRO } \\
\hline $\mathrm{H}=\frac{\rho \mathrm{AP}_{\mathrm{T}}}{\rho \mathrm{AI}_{\mathrm{T}}} \times \rho \mathrm{CA}$ & 0,1131 \\
\hline
\end{tabular}

4.5.2.3 Fixação de Carbono do bairro Santa Cecilia, Piracicaba - SP

O valor encontrado para a fixação de Carbono do bairro Santa Cecília, por meio da videografia foi em 2003:

$$
\mathrm{C}=\rho \mathrm{ACA}=0,1648
$$


4.5.2.4 Atuação da temperatura no bairro Santa Cecilia, Piracicaba - SP

As classes de temperatura de superficie e os porcentuais em que elas ocorrem na área total $\left(\rho_{\mathrm{i}}\right)$, referentes ao bairro Santa Cecília, obtidas por meio da imagem termal, são mostradas nas Figuras 26 e 27 e expostas na Tabela 25.

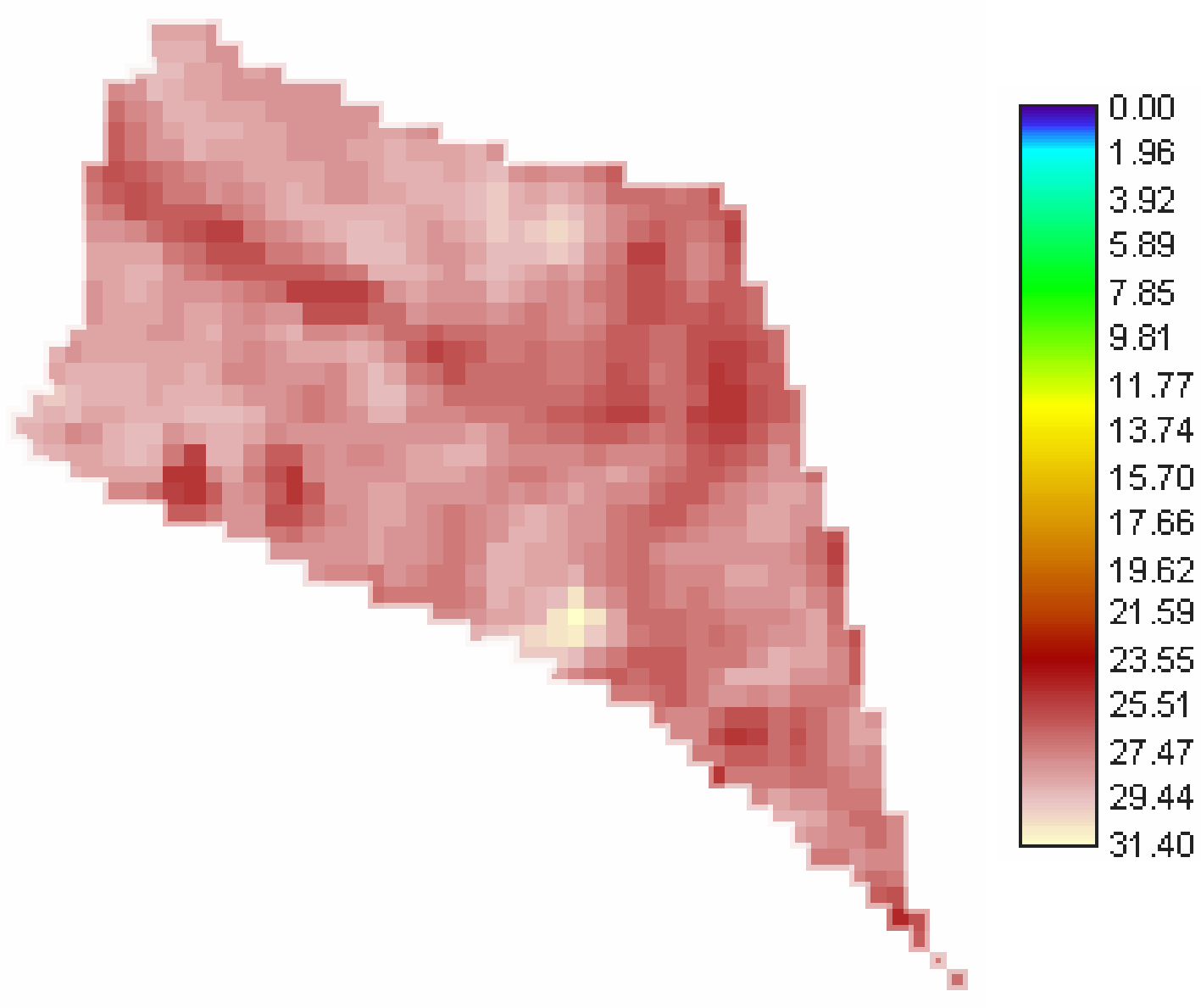

Figura 26- Classes de temperatura de superficie obtidas por imagem de satélite do bairro Santa Cecília Piracicaba - SP, em 2003 
Videografia

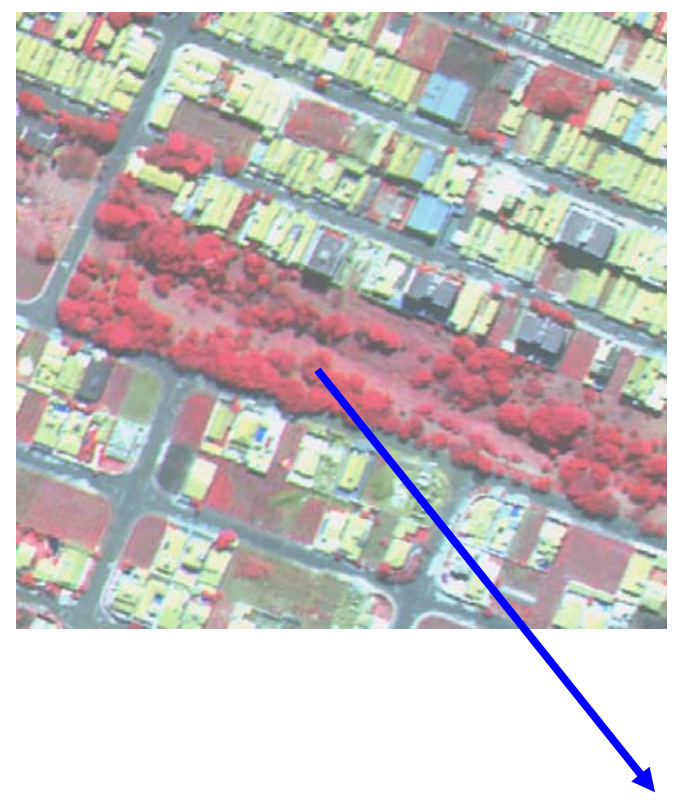

Mapa termal

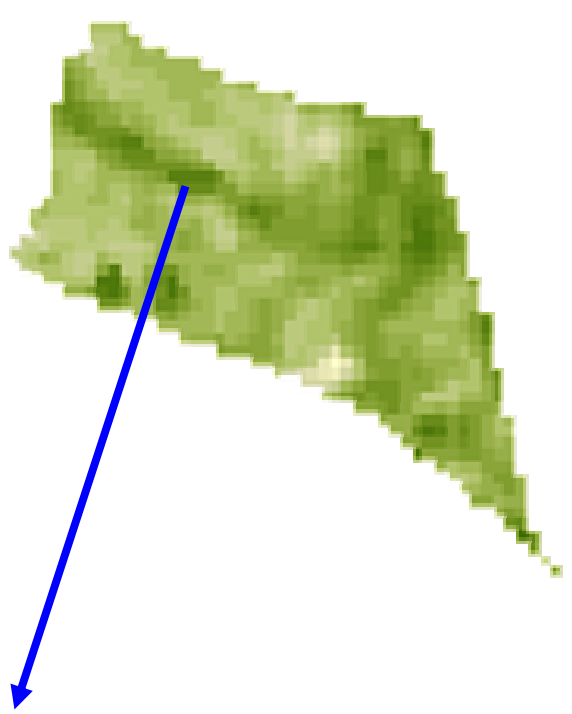

Vegetação em torno do rio

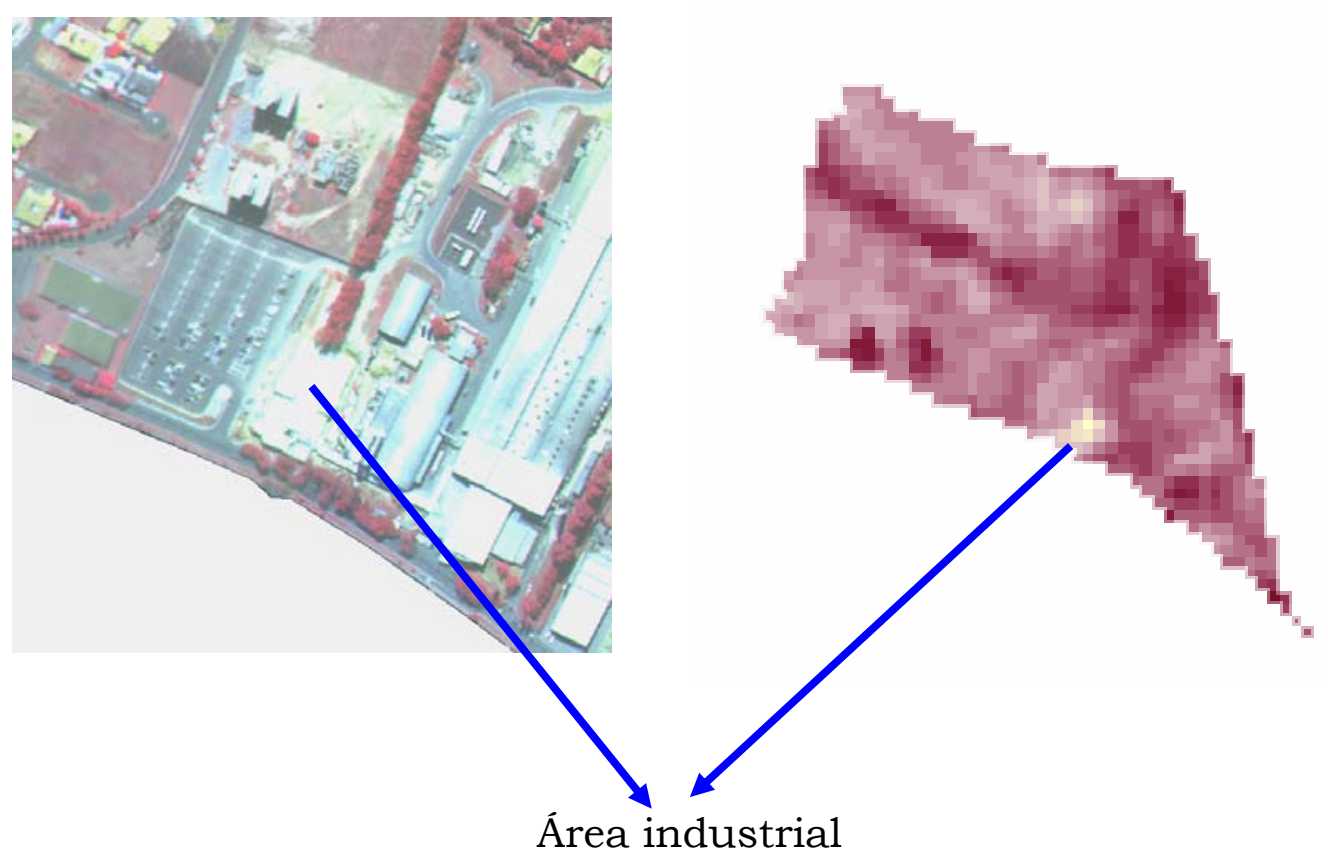

Figura 27 - Termografia (imagem de satélite) comparada à imagem na videografia do bairro Santa Cecília, Piracicaba - SP, em 2003 
A Figura 26 e 27 mostram claramente as variações de temperatura de superficie na área de estudo e a influência do tipo de cobertura de solo da área sobre a TS. A utilização da banda termal 6 do satélite Landsat 7 permitiu a captação das energias refletidas das áreas, interpretadas pelo programa Idrisi, por meio de sua calibração para banda termal, que foi capaz de demonstrar uma diferença de até $7,4^{\circ} \mathrm{C}$ entre as áreas.

Tabela 25. Classes de temperatura de superficie e sua média (limite inferior e superior), porcentuais na área total e média ponderada, obtidas por imagem de satélite de 25/02/2003 do bairro Santa Cecilia, Piracicaba-SP

\begin{tabular}{cccccc}
\hline $\begin{array}{c}\text { Classe de } \\
\text { tempe- } \\
\text { ratura }\end{array}$ & $\begin{array}{c}\text { Limite } \\
\text { inferior } \\
\left({ }^{\circ} \mathrm{C}\right)\end{array}$ & $\begin{array}{c}\text { Limite } \\
\text { superior } \\
\left({ }^{\circ} \mathrm{C}\right)\end{array}$ & $\begin{array}{c}\text { Média da } \\
\text { classe } \\
\left({ }^{\circ} \mathrm{C}\right)\end{array}$ & $\begin{array}{c}\text { Porcentual } \\
\text { na área }\end{array}$ & $\begin{array}{c}\text { Temperatura de } \\
\text { Superficie i }\left(\mathrm{S}_{\mathrm{i}}\right) \text { no } \\
\text { porcentual }\left(\mathrm{\rho}_{\mathrm{i}}\right)\end{array}$ \\
\hline 1 & 24,49 & 24,81 & 24,65 & 0,0010 & 0,0249 \\
2 & 24,81 & 25,12 & 24,96 & 0,0121 & 0,3026 \\
3 & 25,12 & 25,43 & 25,28 & 0,0000 & 0,0000 \\
4 & 25,43 & 25,75 & 25,59 & 0,0222 & 0,5687 \\
5 & 25,75 & 26,06 & 25,90 & 0,0485 & 1,2560 \\
6 & 26,06 & 26,38 & 26,22 & 0,0778 & 2,0393 \\
7 & 26,38 & 26,69 & 26,53 & 0,0000 & 0,0000 \\
8 & 26,69 & 27,00 & 26,85 & 0,1061 & 2,8474 \\
9 & 27,00 & 27,32 & 27,16 & 0,1101 & 2,9904 \\
10 & 27,32 & 27,63 & 27,47 & 0,1273 & 3,4968 \\
11 & 27,63 & 27,95 & 27,79 & 0,0000 & 0,0000 \\
12 & 27,95 & 28,26 & 28,10 & 0,1879 & 5,2799 \\
13 & 28,26 & 28,57 & 28,42 & 0,1515 & 4,3056 \\
14 & 28,57 & 28,89 & 28,73 & 0,0000 & 0,0000 \\
15 & 28,89 & 29,20 & 29,04 & 0,0960 & 2,7871 \\
16 & 29,20 & 29,52 & 29,36 & 0,0384 & 1,1269 \\
17 & 29,52 & 29,83 & 29,67 & 0,0131 & 0,3896 \\
18 & 29,83 & 30,14 & 29,99 & 0,0020 & 0,0606 \\
19 & 30,14 & 30,46 & 30,30 & 0,0000 & 0,0000 \\
20 & 30,46 & 30,77 & 30,61 & 0,0040 & 0,1237 \\
21 & 30,77 & 31,09 & 30,93 & 0,0010 & 0,0312 \\
22 & 31,09 & 31,40 & 31,24 & 0,0010 & 0,0316 \\
$\mathrm{TS}=$ & & & & & 27,6624 \\
\hline$\left(\mathrm{TS} \mathrm{X} \mathrm{p}_{\mathrm{i}}\right)$ & & & & & \\
& & & & & \\
\hline
\end{tabular}


A partir dos dados obtidos no satélite $\left(\mathrm{TS}_{\mathrm{i}}\right)$ e da temperatura do ar (TA), aplicou-se a fórmula para atuação da temperatura (T) e calcularam-se os valores que estão relacionados na Tabela 26.

Tabela 26. Parâmetros avaliados para o cálculo da atuação da temperatura no bairro Santa Cecília, Piracicaba - SP

\begin{tabular}{cc}
\hline Parâmetro & Dados \\
\hline Temperatura de superficie total $(\mathrm{TS})\left({ }^{\circ} \mathrm{C}\right)$ & 27,66 \\
Temperatura média do ar $(\mathrm{TA})\left({ }^{\circ} \mathrm{C}\right)$ & 27,70 \\
Porcentual de ambiente resfriado $(\rho \mathrm{\rho r})$ & 0,5934 \\
Temperatura de resfriamento $(\mathrm{Tr})$ & 1,0014 \\
ATUAÇÃO DA TEMPERATURA & 0,5232 \\
$\mathrm{~T}=\operatorname{Tr} \times \rho \mathrm{Ar}$ & \\
\hline
\end{tabular}

Os dados de temperatura de superfície expressaram claramente a influência do tipo de cobertura de solo presente na área (figura 20). É possivel caracterizar uma influência da vegetação sobre o microclima do bairro, mas extrapolar esses dados para os complexos fatores que compõem as ilhas de calor urbanas não seria coerente. Nichol (1994) observou que os dados termais indicam mosaicos de microclimas potenciais na camada de cobertura urbana, na altura ou abaixo dos telhados, influenciados pelas características térmicas da superficie ativa imediata e não pela advectividade horizontal que é mais característica das ilhas de calor noturnas. Portanto, como aquela autora coloca, referindo-se a seus dados, semelhantes aos aqui apresentados, eles expressam "ilhas de calor derivadas de satélite". 
Embora a área não seja densamente povoada e totalmente urbanizada, a verificação de temperatura de superficie serve como exemplo das modificações que os tipos de cobertura urbana podem causar no microclima. Comparando-se os dados aqui apresentados com o trabalho de Bias et al. (2003), para a periferia do Distrito Federal, onde houve variação de até $9^{\circ} \mathrm{C}$ nos dados térmicos obtidos às 9:45 h da manhã, pode-se dizer que a diferença de até $7,4{ }^{\circ} \mathrm{C}$ aqui levantada é considerável, uma vez que não há grande densidade de vegetação, nem tampouco de área construída.

\subsubsection{Cálculo do IQEVUe do bairro Santa Cecília, Piracicaba - SP, em 2003}

O valor encontrado para o IQEVUe do bairro Santa Cecília para o ano de 2.003 é:

$$
\mathrm{IQEVUe}=\mathrm{S}+\mathrm{H}+\mathrm{C}+\mathrm{T}=\mathbf{0 , 9 9 4 0}
$$

\subsubsection{Aplicação do IQEVUe}

As variações do IQEVUe, de acordo com os diferentes valores de seus parâmetros, são apresentadas na Tabela 27. As situações utilizadas para extrapolação dos dados para novos cálculos do IQEVUe são baseadas em situações ideais de arborização urbana, levantadas na literatura, situações extremas de tipos de cobertura do solo, algumas de efetivação de melhorias e, outras, de caráter meramente fictício, visando, apenas, à obtenção de situações e dados para discussão. 
Tabela 27. Variações dos componentes do Índice de Qualidade do Espaço Verde Urbano com função Ecológica (IQEVUe), do bairro Santa Cecília, Piracicaba - SP

\begin{tabular}{cccccc}
\hline Situação & $\begin{array}{c}\text { Sombre- } \\
\text { amento }\end{array}$ & Hidrologia & $\begin{array}{c}\text { Fixação de } \\
\text { Carbono }\end{array}$ & $\begin{array}{c}\text { Tempe- } \\
\text { ratura }\end{array}$ & IQEVUe \\
\hline $\begin{array}{c}\text { Bairro Santa } \\
\text { Cecilia em 2003 }\end{array}$ & 0,1929 & 0,1131 & 0,1648 & 0,5232 & 0,9940 \\
Situação 1 & 0,5871 & 0,1662 & 0,2052 & 0,6112 & 1,5698 \\
Situação 2 & 0,1929 & 0,1236 & 0,1648 & 0,5534 & 1,0346 \\
Situação 3 & 0,1929 & 0,1768 & 0,2576 & 0,5218 & 1,1491 \\
Situação 4 & 0,1929 & 1,0721 & 0,4582 & 1,5221 & 3,2453 \\
Situação 5 & 0 & 0,1008 & 0,1538 & 0,4863 & 0,7409 \\
Situação 6 & 0,1929 & 0,1131 & 0,1648 & 0,5474 & 0,1990 \\
\hline
\end{tabular}

As simulações para obtenção dos índices são mostradas pela Tabela 27 e comentadas a seguir:

Situação 1 - Melhoria do sombreamento de calçadas

Os dados obtidos no item 4.1 mostraram que há a possibilidade, no bairro Santa Cecília, de elevar-se o número de árvores $/ \mathrm{km}$ de uma média de 39,86, para 82,42. Árvores de porte maior são capazes de um melhor sombreamento que arbustos e palmeiras. Portanto, considera-se, para essa simulação, que todas as árvores possuam altura e diâmetro de copa com as seguintes classes máximas: $>10 \mathrm{~m}$ e $>6 \mathrm{~m}$, respectivamente. Com isso, o porcentual de árvores de calçada aumentaria para $4,7 \%$, se o levantamento fosse feito em campo, e para $6,8 \%$, se fosse utilizado o mesmo recorte feito na videografia (ver 4.4.3). 
Para a diversidade ideal, neste trabalho, é aceita a premissa de Grey \& Deneke (1978), Miller \& Miller (1991) e Santamour (2002) que diz que cada espécie deve, no máximo, contribuir com $10 \%$ de exemplares, na arborização urbana. Duas espécies, de acordo com a amostragem aleatória simples, apresentaram um número de indivíduos maior que $10 \%$ do total de árvores do bairro. Para seguir tal recomendação, seria necessário retirar, do número de indivíduos dessas espécies, um número de indivíduos suficiente para que elas permaneçam com um máximo de $10 \%$ do total de indivíduos e substituir os excedentes por árvores de espécies com menor freqüência na população do bairro. Dessa forma, o IDS aumentaria para 3,37.

Os outros parâmetros também aumentam, em função do aumento de árvores de calçadas, o que vai influenciar sobre todo o indice.

Os resultados apresentados mostram que, somente com a possibilidade de se incrementar a cobertura arbórea de calçadas, com o uso de árvores de altura $>10 \mathrm{~m}$ e diâmetro $>6 \mathrm{~m}$, sem que haja um aumento de cobertura arbórea nos outros espaços verdes, o IQEVUe passa a ter um valor $58 \%$ maior que na situação atual.

Por esses dados, verifica-se o quanto a arborização de calçadas é importante como forma de incremento da qualidade do verde urbano. A situação é colocada de maneira qualitativa, pois, se considerássemos apenas a questão quantitativa, tomar-se-iam como base, os dados de IVH e ICVAU levantados no item 4.4. O valor desses índices, para a situação, seria de $24,5 \%$, se fosse considerado o verde total.

Os dados aqui apresentados demonstram que o benefício direto de árvores de calçada deve ser considerado, uma vez que, com o incremento do plantio, pode haver um significativo aumento da qualidade da arborização urbana de uma unidade de paisagem. No 
entanto, para isso tornar-se efetivo, leva-se em consideração que os indivíduos plantados devem possuir porte arbóreo e não arbustivo, com altura de árvores maior que $10 \mathrm{~m}$.

Extrapolando-se os mesmos dados, agora, para o número de arv $/ \mathrm{km}$ possivel de ser alcançado e supondo um plantio, com esse fim, somente de arbustos (com médias de altura de $2,5 \mathrm{~m}$ e de $1,5 \mathrm{~m}$ de diâmetro de copa), ter-se-ia uma diminuição dos beneficios da arborização urbana e o aumento do índice seria de 14,3\%, apenas.

Com arbustos de uma copa maior ( $4,5 \mathrm{~m}$ de diâmetro médio), o aumento do IQEVUe ainda é menor (30,3\%) que o valor de $58 \%$ encontrado quando do uso de árvores.

É importante salientar que não basta uma política de plantio de mudas: é preciso que se tenha em mente a importância do plantio de indivíduos que cumpram o papel desejado na arborização urbana, isto é, o de propiciar beneficios reais à população. No presente trabalho, o enfoque é ecológico e isso deve ser lembrado quando se deseja avaliar os benefícios da vegetação.

Situação 2 - Melhoria da hidrologia de calçadas

Para a melhoria da hidrologia de calçadas, considera-se a hipótese de todas elas serem calçadas verdes, ou seja, com algum tipo de forração. O aumento do IQEVUe, neste caso, seria de 4\%. O parâmetro dessa simulação que aumenta é a hidrologia, somente, por causa do aumento de permeabilidade, não sendo este aumento extensivo aos outros parâmetros de qualidade.

A área estudada, neste trabalho, ainda possui muitos terrenos vazios, portanto, sem impermeabilização. Então, parece que um incremento de $4 \%$ no índice não é muito. Porém, quando o bairro estiver 
inteiro ocupado por construções, a importância de calçadas verdes é maior, sendo que não haverá muita possibilidade de expansão de áreas para captação de água e diminuição de escoamento superficial.

Dos vários problemas que se apresentam no planejamento urbano, talvez um dos maiores seja o de resolver problemas de enchentes em locais muito impermeabilizados. $O$ índice proposto, por ser diretamente proporcional à permeabilidade do solo, esta serve como representação indireta da hidrologia do local. Como a finalidade é a de simplificar os parâmetros, a quantidade de precipitação não é utilizada, mas sabe-se que, conforme aumenta a enxurrada, melhor é a presença de áreas permeáveis próximo às residências.

Situação 3 - Melhoria da cobertura arbórea

Considera-se, nessa extrapolação, que nos locais do bairro onde há somente presença de forração, o preenchimento com cobertura arbórea teria um reflexo na melhoria do índice. Nesse caso, haverá influência em todos espaços verdes, excetuando-se os espaços verdes de calçadas, ou seja, no índice, o parâmetro sombreamento não será modificado.

Em locais da cidade onde não existe mais a possibilidade de se aumentar espaços verdes, como espaços livres de uso público, a maneira de incrementar a presença de verde pode ser a de utilizarem-se áreas particulares ou espaços viários. Em locais como balões e canteiros centrais, há algumas restrições, mas políticas de adensamento de arborização nesses locais podem ser feitas, com árvores de grande porte para amenização da temperatura, maior fixação de Carbono e maior interceptação de chuva, sem que haja prejuizo para os outros equipamentos urbanos. Planejadores devem ficar atentos durante a escolha das espécies a serem plantadas, optando, sempre que possivel, 
por árvores e não por arbustos e palmeiras, de contribuição muito mais estética que ecológica, como tem ocorrido.

A arborização, dentro de áreas particulares, pode ser feita quando se trata de áreas industriais, no caso de cumprimento de leis de compensação para aumento de construção, mas, em áreas comerciais e residenciais, as leis ainda são falhas e poucas cidades possuem código para incentivo da presença do verde.

Situação 4 - Pequeno porcentual de ambiente construído e grande porcentual de cobertura arbórea

Nesse caso, considera-se o ambiente construído como sendo somente $30 \%$ da área total, o resto é preenchido com cobertura arbórea. Essa é uma situação fictícia, pois o porcentual atual de área ocupada com ambiente construído é de $60 \%$ e, para diminuir esse valor, seria necessário uma reforma urbana que eliminasse várias construções. Por outro lado, um ambiente com grande cobertura arbórea, local muito agradável para a vida nas cidades, representaria aqui uma condição extrema para avaliar se o IQEVUe é equivalente aos beneficios propiciados por este tipo de ambiente.

De fato, para um local com as características citadas, o valor de IQEVUe é 3,3 vezes maior que o do resultado real.

Situação 5 - Alta densidade de ambiente construído Calçadas sem arborização

Aqui, a simulação é considerar que a área em questão tem $90 \%$ de ambiente construído e somente 10\% com cobertura arbórea, sem arborização de calçadas. Essa situação vem acontecendo em grandes centros urbanos, onde aumenta a pressão por ocupação dos locais 
disponiveis para arborização. Questões como garagens que ocupam toda a frente de calçadas, calçadas estreitas e grande quantidade de fiação aérea têm restringido a presença de árvores nas calçadas.

\section{Situação 6 - Alteração na temperatura do ar}

Em todos os casos analisados, as simulações realizadas foram feitas a partir da modificação de um parâmetro, o que teve reflexos sobre os valores dos outros. No caso de temperatura, houve somente modificação no que se refere ao porcentual de área resfriada e não na relação temperatura do ar/temperatura de resfriamento. Isso se deve ao fato de as medidas de temperatura de superficie do satélite terem sido verificadas apenas em uma data. Com certeza, nas simulações discutidas anteriormente (1 a 5), haveria uma modificação da temperatura de superficie obtida pelo satélite, caso isso fosse medido com as condições presentes nas situações daquelas simulações.

Foi usada a média diária da temperatura do ar como forma de se obter a temperatura de resfriamento, com vistas ao cálculo do IQEVUe, porque essa média é fácil de obter. Isso facilita o uso do índice, razão pela qual não se optou, quando foi feita a proposta do IQEVUe, pela temperatura do ar no momento de passagem do satélite.

Nesta simulação 6, estima-se o IQEVUe usando a temperatura do ar no momento de passagem do satélite (10:30h), o que confere maior precisão na obtenção do índice, neste caso.

A temperatura do ar no momento da passagem do satélite $\left(28,98^{\circ} \mathrm{C}\right)$ foi maior que a média diária $\left(27,7^{\circ} \mathrm{C}\right)$. Esse valor fez com que o indice se elevasse $2 \%$ em relação ao valor real, uma vez que a relação da temperatura do ar com a temperatura de superficie foi maior. 


\title{
5 CONSIDERAÇÕES FINAIS
}

\begin{abstract}
A idéia original de realizar este trabalho surgiu a partir de discussões feitas em encontros e congressos de arborização urbana sobre a utilização de índices que pudessem representar a presença do verde nas cidades. Uma das questões levantadas, então, era que metodologia empregar para tal fim. Alguns usavam somente medidas de cobertura arbórea de espaços livres públicos, outros consideravam as árvores do sistema viário. No entanto, havia uma lacuna referente ao papel que a vegetação exercia no meio urbano, sem definir se o importante era a quantidade ou a qualidade do verde. Se, por um lado, alguns consideravam como fundamental a questão da acessibilidade da população ao espaço verde, por eles chamado de área verde, de outra parte, não se negava a importância das árvores de calçada para o conforto térmico e a estética. Então, ocorria uma dualidade: para lazer, as áreas verdes deveriam cumprir seu papel de acessibilidade, enquanto que, para contemplar a questão ecológica, deveriam ser consideradas também as árvores de rua.

O cálculo do índice de área verde era tido, como ainda hoje, um caso particular de índice de espaço livre urbano de uso público. A partir de alguns trabalhos inovadores, o índice de área verde passou a expressar a cobertura vegetal como um todo. Em vários casos, levou-se em consideração a densidade populacional, dando uma idéia de quanto
\end{abstract}


de verde cada cidadão teria à sua disposição. De início, o enfoque era apenas quantitativo, sem abordar a contribuição qualitativa da vegetação.

Atualmente, ainda questiona-se qual metodologia utilizar para a determinação de índices e como conseguir contemplar as muitas contradições presentes nas áreas urbanas.

Este trabalho propõe-se a clarear alguns desses questionamentos, sem pretender dar palavra final, mas reservando-se o direito de propor melhorias de abordagem que teriam, como conseqüência, acréscimo de qualidade de vida ao habitante da cidade.

$\mathrm{O}$ indice elaborado mostrou-se adequado para as avaliações realizadas e para extrapolações de situações do bairro, diferentes das atuais. Não houve incoerências, do ponto de vista matemático, na representação das características simuladas e os valores foram indicativos das situações analisadas, o que, de certa forma, valida o índice proposto.

A pertinência dos valores obtidos para o IQEVUe, verídicos ou simulados, autoriza afirmar que este índice pode servir de base no diagnóstico do cumprimento das funções ecológicas do verde para planejamento urbano.

Os resultados do trabalho demonstraram que dados somente quantitativos podem omitir fatores importantes, limitando o delineamento de ações de manejo, em cidades.

Para uso localizado, o IQEVUe pode ser aplicado diretamente, mas, para que os responsáveis pela gestão urbana possam definir prioridades e tomar decisões, o índice precisa ser testado em situações variadas. Também, ainda é preciso estabelecer a amplitude dos valores desse índice, definindo os limites inferior e superior ideais. 
Como uma proposta inicial para verificação da qualidade, os parâmetros de uso direto representaram a contento o bairro estudado neste trabalho, mas o objetivo é que o IQEVUe seja de uso generalizado, padronizando a comparação entre unidades de paisagem, dentro da cidade e entre cidades. Variações irão ocorrer entre as peculiaridades de cada área, o que demandará, dos aplicadores desse índice, bom senso e uma adequação aos fatores levantados para diagnóstico.

Uma proposta de índice como esta não é restrita aos foros acadêmicos, devendo sua discussão ser estendida à comunidade e fomentada pela Sociedade Brasileira de Arborização Urbana (SBAU). 


\section{CONCLUSÕES}

A comparação do censo com as amostragens aleatória simples e estratificada mostra que, para árvores de calçada, a mais fiel à realidade é a amostragem aleatória simples;

A videografia apresenta-se como um excelente método para o detalhamento da cobertura vegetal em áreas urbanas;

O Índice de Espaço Livre de Uso Público (IELUP) e a Porcentagem de Espaços Livres de Uso Público (PELUP) apresentam-se elevados para área estudada;

O Índice de Cobertura Vegetal em Áreas Urbanas (ICVAU) e o Índice de Verde por Habitante (IVH) são superiores se comparados a unidades de paisagens semelhantes;

Os métodos empregados para avaliação dos parâmetros utilizados para compor o IQEVUe são eficientes em mensurar a realidade em campo; 
O Índice de Qualidade do Espaço Verde Urbano com Função Ecológica (IQEVUe), aqui proposto, é capaz de qualificar os espaços verdes e, conseqüentemente, seus beneficios à população, provando que é uma proposta mais abrangente que o Índice de Áreas Verdes (IAV);

O IQEVUe pode se constituir numa ferramenta muito útil para o planejamento urbano e conseqüente melhoria na qualidade de vida. 


\section{REFERÊNCIAS BIBLIOGRÁFICAS}

ANDRADE, T.O. Inventário e análise da arborização viária da estância turística de Campos do Jordão, SP. Piracicaba, 2002. 112 p. Tese (Mestrado) - Escola Superior de Agricultura "Luiz de Queiroz", Universidade de São Paulo.

ARNFIELD, A.J. A simple model of urban canyon energy budget and its validation. Physical Geography, v. 11, n. 2, p. 305-326, 2000.

ASAEDA, T.; CA, V.T. The subsurface transport of heat and moisture an its effect on the environment: a numerical model. Boudary-Layer Meteorology, v. 65, p. 159-179, 1993.

BAJWA, M.M. Role of integrated landscape design in energy conservation in detached dwellings in the Arabian Gulf region. Renewable Energy, v. 6, n. 2, p. 139-150, 1995.

BAPTISTA, G.M.M. Estudo multitemporal do fenômeno Ilhas de Calor no Distrito Federal. Revista Meio Ambiente, n. 02, p. 03-17, 2002.

BARKER, P.A. Ordinance control of street trees. Journal of arboriculture, v. 1, n. 11, p.212-216, 1975.

BEER, A.R.; DELSHAMMAR T; SCHILDWACHT, P. A changing understanding of the role of greenspace in high-density housing: a european perspective. Built Environment, v. 29, n. 2, p. 132-170, 2003. 
BERNATZKY, A. The contribution of trees and green space to a town climate. Energy and Buildings, v. 5, n. 1, p. 1-10, 1982.

BIAS, E.S.; BAPTISTA, G.M.M.; LOMBARDO M.A. Análise do fenômeno de ilhas de calor urbanas, por meio da combinação de dados landsat e ikonos. In: SIMPÓSIO BRASILEIRO DE SENSORIAMENTO REMOTO, 9., Belo Horizonte, 2003. Anais. Belo Horizonte: INPE, 2003, p. $1741-1748$.

BIONDI, D. Diagnóstico da arborização de ruas da cidade do Recife. In: ENCONTRO NACIONAL SOBRE ARBORIZAÇÃO URBANA, 1, Porto Alegre, 1985. Anais. Porto Alegre: Secretaria Municipal do Meio Ambiente, 1985. p.87-88.

BRASIL. LEI FEDERAL no 4771 de 15 de setembro de 1965. Código florestal.

BRASIL. Lei Federal nº 6766 de 19 de dezembro de 1979. Dispõe sobre o parcelamento do solo urbano.

BRASIL. LEI FEDERAL no 7803 de 19 de dezembro de 1989. Altera o artigo $2^{\circ}$ do Código Florestal.

BRASIL. Lei Federal no 9.785 de 29 de janeiro de 1999. Altera a lei de uso e parcelamento do solo.

BUENO, C.L. Estudo da atenuação da radiação solar incidente por diferentes espécies arbóreas. Campinas, 1998. 136p. Dissertação (M.S.) - Faculdade de Engenharia Civil, Universidade Estadual de Campinas.

CÂMARA, G.; DAVIS, C.; MONTEIRO, A.M.V.;PAIVA J.A.; D’ALGE, J.C.L. Geoprocessamento: Teoria e Aplicações http://www.dpi.inpe.br /gilberto/livro, 199?. 
CÂMARA, G.; MEDEIROS, J.S. Mapa e suas representações computacionais. In: ASSAD, E.D.; SANO, E.E. Sistema de informações geográficas: aplicações na agricultura. Brasília: Embrapa, SPI; Embrapa, CPAC, 1998. cap. 3, p. 31-43.

CAMPBELL, J.B. Introduction to remote sensing. New York: The Guildford, 1987. 551p.

CANTON, M.A; CORTEGOSO, J.L.; de ROSA, C. Solar permeability of urban trees in cities of western Argentina. Energy an Buildings, v. 20, n. 3, p. 219-230, 1994.

CARRARA, A. L. R. Análise comparativa dos indices de vegetação em áreas urbanas obtidas de dados TM-LANDSAT e HRV-SPOT: Cidade de Taubaté.. São José dos Campos: INPE, 1992. 193p.

CAVALHEIRO, F. Metodologia para determinação do índice de espaços livres urbanos. In: ENCONTRO BRASILEIRO SOBRE ARBORIZAÇÃO URBANA, 6., Londrina. Anais, 1996 (no prelo).

CAVAlHEIRO, F.; DEL PICCHIA, P.C.D. Áreas verdes: conceitos, objetivos e diretrizes para o planejamento. In: ENCONTRO BRASILEIRO SOBRE ARBORIZAÇÃO URBANA, 4., Vitória, 1992. Anais Vitória: Sociedade Brasileira de Arborização Urbana, 1992. p. 29-38.

CAVALHEIRO, F.; NUCCI, J.C.; Espaços livres e qualidade de vida urbana. Paisagem, Ambiente, Ensaios. São Paulo, n. 11, p. 277-288, 1998.

CHING, J.K.S.; CLARKE, J.S.; GODOWITCH, J.M. modulation of heat flux by different flux scales of advection in an urban environment. Boundary-Layer Meteorology, v. 25, p. 171-191, 1983.

COCHRAN, W.G. Sampling techniques. 3 ed. New York: John Wiley, 1977. 428 p. 
CONGALTON, R.G.; ODERWALD, R.G.; MEAD, R.A. Assessing Landsat classification accuracy using discrete multivariate analysis statistical techniques. Photogrametric Engineering and Remote Sensing, v. 49, n. 12, p. 1671-1678, 1983.

COUTO, H.T.Z. Métodos de amostragem para avaliação de árvores de ruas. In: CONGRESSO BRASILEIRO DE ARBORIZAÇÃO URBANA, 2., ENCONTRO NACIONAL SOBRE ARBORIZAÇÃO URBANA, 5., São Luis, 1994. Anais. São Luís: Sociedade Brasileira de Arborização Urbana, 1994. p.169-179.

COUTO, HTZ.; VETORAZZI, C.A. FERRAZ, S.F. de B.; POMPERMAYER NETO P. Airborne videography as a data source for the decisionmaking process in agriculture. In: INTERNATIONAL CONFERENCE ON GEOSPATIAL INFORMATION IN AGRICULTURE AND FORESTRY, 2., Lake Buena Vista, 2000. Proceedings. Lake Buena Vista: ERIM, 2000. p. 459-461.

DOUGLAS, I. The urban environment. Victoria (Australia): Edward Arnold, 1987. p. 229.

ESCADA, M.I.S. Caracterização dos espaços livres de uso público de São José dos Campos. São José dos Campos, 1992. 133p. Dissertação (M.S.) - Instituto de Pesquisas Espaciais.

ESTADOS UNIDOS. Department of Agricultural Research Service. National Arboretum. Washington: USDA, 2002. p. 57-65p.

EVERITT, J.H.; ESCOBAR, D.E.; VILLARBAL, R.; NORIEGA, J.R.;

DAVIS, M.R. Airborne video system for agricultural assessment. Remote Sensing of Environment, v. 35, p. 231-242, 1991. 
FORESTI, C.; PEREIRA, M. D. B.; FLOREnZANO, T. G. Aplicação dos indices de vegetação nos estudos do ambiente urbano de São José dos Campos com utilização de dados TM-LANDSAT. In: CONGRESSO BRASILEIRO DE DEFESA DO MEIO AMBIENTE, 1., Rio de Janeiro, 1987. Anais. 1987. p.293-306

GOYA, C.R. Levantamento sistemático das áreas públicas livres de edificações e padrões de urbanização nas cidade de Bauru. In: ENCONTRO NACIONAL SOBRE ARBORIZAÇÃO URBANA, 3, Curitiba, 1994. Anais. Curitiba: FUPEF, 1990. p.188-196.

GREY, G.W.; DENEKE, F.J. Urban Forestry. New York: John Wiley, 1978. 279 p.

GRIMMOND, C.S.B; OKE, T.R. Comparison of heat fluxes from summertime observations in the suburbs of four North American cities. Journal of Applied Meteorology, v. 38, p. 922-940, 1995.

GRIMMOND, C.S.B; OKE, T.R. STEYN, D.G. Urban water balance. 1. A model for daily totals. Water Resources Research, v. 22, p. 13971403, 1986.

GRIMMOND, C.S.B.; SOUCH, C.; HUBBLE, M.D. Influence of tree cover on summertime surface energy balance fluxes. San Gabriel Valley, Los Angeles. Climate Research, v. 6, p. 45-57, 1996.

GUZZO, P. Estudo dos Espaços livres de uso público da cidade de Ribeirão Preto/SP, com detalhamento da cobertura vegetal e áreas verdes públicas de dois setores urbanos. Rio Claro, 1999. 125p. Dissertação (M.S.) - Instituto de Geociências e Ciências Exatas / Campus de Rio Claro, Universidade Estadual Paulista "Júlio de Mesquita Filho".

HALL, M.J. Urban hydrology. London: Elsevier Applied Science, 1984. 299 p. 
HENKE-OLIVEIRA, C.; SANTO, J.E. dos; PIRES, J.S.R. Geoprocessamento e fotografias aéreas aplicadas no estudo da vegetação e do desenvolvimento urbano. In: I FÓRUM DE DEBATES ECOLOGIA DA PAISAGEM E PLANEJAMENTO AMBIENTAL, Rio Claro, 2000. Anais. Rio Claro: SEB, 2000, p. 1-9.

HUANG, J.H.; AKBARI, H.; TAHA, H.; ROSENFIELD, A. The potential of vegetation in reducing summer cooling loads in redesidential buildings. Journal of Climate Appling Meteorology, v. 26, p. 11031106, 1987.

INSTITUTO BRASILEIRO DE GEOGRAFIA E ESTATÍSTICA. Sinopse preliminar do censo demográfico. São Paulo: Fundação Instituto de Geografia e Estatística 1991, v. 1, 233 p.

INSTITUTO BRASILEIRO DE GEOGRAFIA E ESTATÍSTICA - CD-ROM. Censo demográfico de 2000 (compact disc). São Paulo: Fundação Instituto de Geografia e Estatística, 2001.

JAUREGUI, E. Heat island development in Mexico City. Atmosphere, v. 31, p. 3821-3831, 1987.

JENSEN, J.R. Introductory digital image processing: a remote sensing perspective. 2. ed. New Jersey: Prentice Hall, 1996. 316 p.

JO, H. Impacts of urban greenspace on offsetting carbon emission for middle Korea. Journal of Environmental Management, v. 64, p. 115-126, 2002.

JO, H.; McPHERSON, E.G. Carbon storage and flux in urban residential greenspace. Journal of Environmental Management, v. 45, p. 109133, 1995.

JOHNSON, A.D.; GERHOLD, H.D. Carbon storage by utility-compatible trees. Journal of Arboriculture, v. 27, n. 2, p. 57-68, 2001. 
KJELGREN, R.; MONTAGUE, T. Urban tree transpiration over turf and asphat surfaces. Atmospheric Environment, v. 32, n.1, p. 35-41, 1998.

LILLESAND, T.M.; KIEFFER, R.W. Remote sensing and image interpretation. 2. ed. Chichester: John Wiley, 1994. 750 p.

LIMA, A.M.L.P. Análise da arborização viária na área central e em seu entorno. Piracicaba, 1993. 238 p. Tese (Doutorado) - Escola Superior de Agricultura "Luiz de Queiroz", Universidade de São Paulo.

LIMA, A.M.L.P.; CAVALHEIRO, F. NUCCI, J.C.; SOUZA, M.A.L.B.; FIALHO, N.O.; DEL PICCHIA, P.C.D. Problemas de utilização na conceituação de termos como espaços livres, áreas verdes e correlatos. In: CONGRESSO BRASILEIRO DE ARBORIZAÇÃO URBANA, 5, São Luiz, 1994. Anais. São Luiz: Sociedade Brasileira de Arborização Urbana, 1994. p. 539-553.

LIMA, P.C.F.; OLIVEIRA, V.R.; NASCIMENTO, C.E.S.; TORRES, S.B. Diagnóstico da arborização de ruas de Petrolina - PE. In: ENCONTRO NACIONAL SOBRE ARBORIZAÇÃO URBANA, 3., Curitiba, 1990. Anais. Curitiba, S. ed., 1990. p.41-53.

LLANDERT, L.R.A. Zonas verdes y espacios libres em la ciudad. Madrid: Instituto de Estudios de Administración Local, 1982. 538 p.

LOMBARDO, M. A ilha de calor nas metrópoles. O exemplo de São Paulo, São Paulo: Hucitec, 1985. 244p.

LOWE, J.L.; OSWALD, B.P.; COLEMAN, T.L.; TADESSE, W. EVERITT, J.H. ESCOBAR, D.E.; DAVIS, M.R. Comparison of conventional ground sampling and remote sensing techniques for mapping forest vegetation. USDA: Capacity Building Grants Program and USDA-CSREES, 1995, p.31-52. 
MACO, S.E. McPHERSON, E.G. Assessing canopy cover over streets and sidewalks in street tree populations. Journal of Arboriculture, v. 28 , n. 6, 2002.

MARTINS, F.M.; SANTOS, F.A.M. Técnicas usuais de estimativa da biodiversidade. Revista Holus, v. 1, p. 236-267, 1999.

McPHERSON, E.G.; ROWNTREE, R.A. Using structural measures to compare street tree population. Landscape Journal, v. 8, p. 13-23, 1986.

MENEGUETTI, G.I. Estudo de dois métodos de amostragem para inventário da arborização de ruas dos bairros da orla marítima do município de Santos, SP. Piracicaba, 2003. 100 p. Dissertação (Mestrado) - Escola Superior de Agricultura "Luiz de Queiroz", Universidade de São Paulo.

MEUNIER, I.MJ.; BARROS, S.S.U. de; FERRAZ, J.S.F. Avaliação da arborização de ruas em duas regiões político-administrativas de Recife, PE. In: ENCONTRO NACIONAL SOBRE ARBORIZAÇÃO URBANA, 9, Brasília, 2001. Livro de Resumos. Brasília, Governo do Distrito Federal, 2001. 75 p.

MICHI, S.M.P.; COUTO, H.T.Z. Estudo de dois métodos de amostragem de árvores de rua na cidade de Piracicaba - SP. In: CURSODE TREINAMENTO SOBRE PODA EM ESPÉCIES ARBÓREAS FLORESTAIS E DE ARBORIZAÇÃO URBANA, 1., Piracicaba, 1996. Piracicaba, IPEF/ESALQ-USP, 1996, p. 11-17.

MILANO, M.S. Planejamento da arborização urbana: relações entre áreas e ruas arborizadas. In: ENCONTRO NACIONAL SOBRE ARBORIZAÇÃO URBANA, 3, Curitiba, 1994. Anais. Curitiba: FUPEF, 1990. p.60-71. 
MILANO, M. S. Curso sobre arborização urbana. Curitiba: FUPEF, 1991. 94p.

MILANO, M.S. Métodos de amostragem para avaliação de arborização de ruas. In: CONGRESSO BRASILEIRO DE ARBORIZAÇÃO URBANA, 2., ENCONTRO NACIONAL SOBRE ARBORIZAÇÃO URBANA, 5, São Luis, 1994. Anais. São Luís: Sociedade Brasileira Urbana, 1994. p. 163-168.

MILANO, M. S.; SARNOWISKI FILHO, O.; ROBAIO, J.A.M. Estudo comparativo de unidades amostrais utilizadas para inventário qualiquantitativo da arborização de rua em Curitiba. In: CONGRESSO BRASILEIRO DE ARBORIZAÇÃO URBANA, 1., ENCONTRO NACIONAL SOBRE ARBORIZAÇÃO URBANA, 4., Vitória, 1992. Anais. Vitória: Prefeitura Municipal de Vitória, 1992. p.343-350.

MILLER, R.W. Urban forest: planning and managing urban greenspaces. 2.ed. New Jersey: Prentice Hall, 1997. 502p.

MILLER R.H. e MILLER R.W. Planting survival of selected street tree tax. Journal of Arboriculture, v. 17, n.7. p. 185-191, 1991.

NICHOL, J.E. A gis-based approach to microclimate monitoring in Singapore's high-rise housing estates. Photogrammetric Engineering \& Remote Sensing, v. 60, n. 10, p. 1225-1232, 1994.

NIXON, P.R.; ESCOBAR, D.E.; MENGES, R.M. A multiband video system for quick assessment of vegetal condition and discrimination of plant species. Remote Sensing of Environment, v. 17, p. 203208, 1985.

NOVO, E.M.L.M. Sensoriamento remoto: principios e aplicações. São Paulo: Edgard Blücher, 1992. 308 p. 
NUCCI, J.C. Qualidade ambiental e adensamento: um estudo do planejamento da paisagem do distrito de Santa Cecília (MSP). São Paulo, 1996. 229 p. Tese (Doutorado) - Faculdade de Filosofia, Letras e Ciências Humanas, Universidade de São Paulo.

NUCCI, J.C.; CAVALHEIRO, F. Manchas de verde e qualidade de vida urbana. In: ENCONTRO INTERDISCIPLINAR SOBRE ESTUDO DA PAISAGEM - PAISAGEM-PAISAGENS, 2., Bauru, Anais/no prelo. 1996.

NUNES, M.L. Metodologias de avaliação da arborização urbana. In: CONGRESSO BRASILEIRO DE ARBORIZAÇÃO URBANA, 1., ENCONTRO NACIONAL SOBRE ARBORIZAÇÃO URBANA, 4., Vitória, 1992. Anais. Vitória: Prefeitura Municipal de Vitória, 1992. p.133145.

OKE, T.R. The distinction between canopy and boundary-layer heat islands. Atmosphere, v. 14, n. 2, p. 268-277, 1976.

OKE, T.R. Canyon geometry and the nocturnal heat island: comparison of scale model and field observation. Journal of Climatology, v.1, n.2, p. 237-254, 1981.

OKE, T.R. The urban energy balance. Progress in Physical Geography, v. 12 , p. 471-508, 1988.

OLIVEIRA, C.H. Planejamento ambiental na Cidade de São Carlos (SP) com ênfase nas áreas públicas e áreas verdes: diagnóstico e propostas. São Carlos, 1996. 188p. Dissertação (M.S.) - Universidade Federal de São Carlos.

PEET, R.K. Relative diversity indices. Ecology, v. 56, n. 2, p. 496-498, 1975.

PIRACICABA/SP. Lei Municipal no 2.643 de 04 de janeiro de 1985. Disciplina o Parcelamento do solo. 
PIRACICABA/SP. Lei Complementar n ${ }^{\circ} 144$ de 25 de novembro de 2002. Introduz alterações na Lei $\mathrm{n}^{\circ}$ 2.643/85, que "disciplina o parcelamento do solo urbano".

PLATT, R.H. The ecological city: introduction and overview. In: PLATT, R.H.; ROWAN, A.ROWNTREE; MUICK, P.C. The ecological city: preserving and restoring urban biodiversity. Amherst: The University of Massachusetts Press, 1994. 291 p.

POMPERMAYER NETO, P. Utilização da videografia aérea na detecção de áreas com deficiências nutricionais em plantios de eucalipto. Piracicaba, 2002. 75 p. Dissertação (Mestrado) - Escola Superior de Agricultura "Luiz de Queiroz", Universidade de São Paulo.

RACHID, R.; COUTO, H.T.Z. Estudo da eficiência de dois métodos de amostragem de árvores de rua na cidade de São Carlos - SP. Scientia Florestalis, n. 56, p. 59-68, 1999.

RANZANI, G. Subsidios à geografia de Piracicaba. Piracicaba: Instituto Histórico e Geográfico de Piracicaba, 1976. 79 p.

RHODE, H. A comparison of the contributions of various gases to the greenhouse effect. Science, v. 248, p. 1217-1219, 1990.

RICHARDS, N.A. Optimum stocking of urban trees. Journal of Arboriculture, v. 18, n.2, p. 64-69, 1993.

ROTH, M.; OKE, T.R.; EMRY, W.J. Satellite-derived urban heat islands from three coastal and the utilization of such data in urban climatology. International Journal of Remote Sensing, v. 10, p. 1699-1720, 1989.

ROWNTREE, R.A.; NOWAK, D. Quantifying the role of urban forest in removing atmosphere carbon dioxide. Journal of Arboriculture, v. 17, n. 5, 269-275, 1991. 
SANDERS, R.A. Urban vegetation impacts on the urban hydrology of Dayton, Ohio. Urban Ecology, v. 9, p. 361-375, 1996.

MARTINS, F.R.; SANTOS, F.A.M. Técnicas usuais de estimativa da biodiversidade. Revista Holus, número especial, p. 236-267, 2001.

SATTLER, M.A.; SHARPLES, S.; PAGE, J.K. The geometry of the shading of buildings by various trees shapes. Solar Energy, v. 38, n.3, p. 187-201, 1987.

SEKLIZIOTIS, S. A survey of urban open space using colour infra-re aerial photographs. Aston, 1980. 153 p. Thesis (PhD) - University of Aston.

SHIMABUKURO, M.T. Avaliação de classificadores espectrais de imagens TM LANDSAT em áreas rurais densamente ocupadas - o caso da região de Brotas e Torrinha, São Paulo, Brasil. Campinas, 1996. 177 p. Dissertação (Mestrado) - Instituto de Biologia, Universidade Estadual de Campinas.

SILVA, I.J. Redução da carga térmica de radiação através do sombreamento natural. In: CONGRESSO ARGENTINO DE INGENIERIA RURAL, 4.,; CONGRESSO INTERNACIONAL DE INGENIERIA RURAL, 2., Neuquen, 1996, Memórias... Neuquen: Universidad Nacional del Comahue, Universidad Nacional de La Plata, INTA. Centro Regional Patagonia Norte, 1996. p. 799-807.

SIMPSON, J.R. Urban forest impacts on regional cooling and heating energy use: Sacramento Country's urban forest. Journal of Arboriculture, v. 24, n. 4, 1998.

SMITH, D.S. An overview of greenways: their history, ecological context, and specific functions. In: SMITH, D.S.; HELLMUND, P.C.(Ed.). Ecological of greenways: design and function of linear conservation areas. Minneapolis/London: University of Minessota Press, 1993. 22p. 
SPRONKEN-SMITH, R.A.; OKE, T.R. Scale modeling of nocturnal cooling in urban parks. Boundary-Layer Meteorology, v. 93, p. 287312, 1999.

SWANWICK C.; DUNNETT, N.; WOOLLEY, H. Nature, role and value of green space in towns and cities: An overview. P. Built Environment, v. 29, n. 2, p. 94-106, 2003.

TAKAHASHI, L.Y. Arborização urbana: Inventário In: CONGRESSO BRASILEIRO DE ARBORIZAÇÃO URBANA, 2.; ENCONTRO NACIONAL SOBRE ARBORIZAÇÃO URBANA, 5, São Luis, 1994. Anais. São Luís: Sociedade Brasileira de Arborização Urbana, 1994. p.207-215.

TAKAHASHI, L.Y. Sistema informatizado de manejo de arborização de ruas. In: CONGRESSO BRASILEIRO DE ARBORIZAÇÃO URBANA, 1; ENCONTRO NACIONAL SOBRE ARBORIZAÇÃO URBANA, 4, Vitória, 1992. Anais. Vitória: Prefeitura Municipal de Vitória, 1992. p.281290.

TERJUNG, W.H.; LOUIE, S.S.F. A climatic model of urban energy budgets. Geographical Analysis, v. 4, p. 341-367, 1974.

VALENTE, R.O.A. Análise da estrutura da paisagem na bacia do rio Corumbataí, SP. Piracicaba, 2001. 144 p. Dissertação (Mestrado) Escola Superior de Agricultura "Luiz de Queiroz", Universidade de São Paulo.

WHITFORD, V.; ENNOS, A.R.; HANDLEY, J.F. "City form and natural process"- indicators for the ecological performance of urban areas and their application to Merseyside, UK. Landscape and Urban Planning, v. 57, p. 91-103, 2001. 
XIAO, Q.; McPHERSON, E.G.; SIMPSON, J.R.; USTIN, S.L. Rainfall interception by Sacramento's urban forest. Journal of Arboriculture, v. 24, n. 4, p. 235-244, 1998.

VOOGT, J.A.; OKE, T.R. Thermal remote sensing of urban climates. Remote Sensing of Environment, v. 86, p. 370-384, 2003. 


\section{GLOSSÁRIO}

BAP - bifurcação à altura do peito.

“Canyon" urbano (UC - urban canyon) ou abismo - espaço definido por paredes construídas e elementos situados entre construções.

CAP - circunferência à altura do peito.

Calçada verde ou calçada ecológica - calçada com piso de algum tipo de forração.

Densidade Populacional (DP) - número de habitantes por área (hab $\left./ \mathrm{m}^{2}\right)$.

Espaço cinza - é a terra que consiste predominantemente de superfícies seladas, impermeáveis, duras, como concreto, pavimento ou asfalto, avenidas, pátios, estacionamentos.

Espaço livre - parte da área urbana que contribui para amenizar a vista dando uma percepção positiva da paisagem urbana e/ou que tem a virtude de permitir acesso público; combina espaço verde urbano com espaço público.

Espaço verde urbano - é uma expressão usada para todas áreas de terra cobertas por essa definição de espaço verde, sejam elas de acesso público ou não e/ou de administração pública ou não. Ela inclui todas as áreas de parques e lazer, assim como outros espaços verdes especificamente direcionados para recreação e outras finalidades. 
Global Position System (GPS) - sistema global de posicionamento, utilizado para georreferenciamento.

Índice de Áreas Verdes (IAV) - para todo o núcleo urbano.

Índice de Cobertura Vegetal em Área Urbana (ICVAU) - representa a proporção de área coberta com vegetação, em função da área total estudada, expresso em porcentagem.

Índice de Espaços Livres de Uso Público (IELUP) - é a quantidade de área de espaços livres urbanos de uso público, ou seja, as áreas cujo acesso das pessoas é livre, expresso em $\mathrm{m}^{2} /$ hab.

Índice de Verde por Habitante (IVH) - é a quantidade de cobertura vegetal dividido pelo número de habitantes do local, expresso em $\mathrm{m}^{2} /$ hab.

Mancha verde - quantidade de vegetação em área urbana.

Percentual de Áreas Verdes (PAV) - porcentual de áreas verdes.

Porcentagem de Espaços Livres de Uso Público (PELUP) - é a proporção de área de espaços livres urbanos de uso público em relação à área total estudada.

SIG - Sistemas de Informação Geográfica.

Ts - temperatura de superficie.

UBL (Urban Boundary Layer) - camada limite urbana.

UCL (Urban Canopy Layer) - camada de cobertura urbana.

UHI (Urban Heat Island) - ilhas de calor urbano.

Videografia - técnica de sensoriamento remoto por meio de câmera de vídeo que permite captar imagens e analisa-las por meio do computador. 